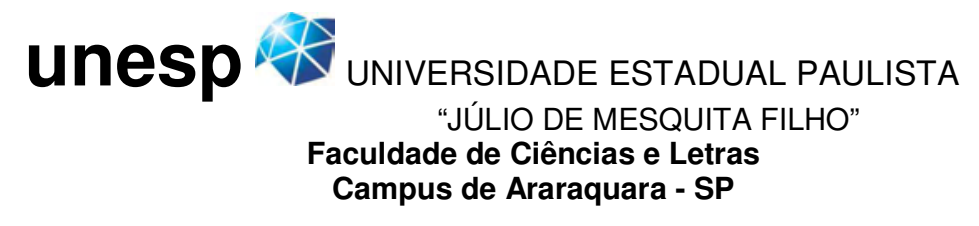

\author{
NATÁLIA CRISTINA DE OLIVEIRA
}

\title{
A CONCORDÂNCIA VERBAL NA REGIÃO NOROESTE DO ESTADO DE SÃO PAULO
}

ARARAQUARA - S.P.

2010 


\section{A CONCORDÂNCIA VERBAL NA REGIÃO NOROESTE DO ESTADO DE SÃO PAULO}

Dissertação de Mestrado apresentada ao Programa de Linguística e Língua Portuguesa da Faculdade de Ciências e Letras - da Universidade Estadual Paulista "Júlio de Mesquita Filho" - Unesp/Araraquara, como requisito para obtenção do título de Mestre em Linguística e Língua Portuguesa.

Linha de pesquisa: Análise fonológica, morfossintática, semântica e pragmática.

Orientadora: Prof ${ }^{\mathrm{a}} \mathrm{Dr}^{\mathrm{a}}$ Odette Gertrudes Luiza Altmann de Souza Campos

Bolsa: CAPES

ARARAQUARA - S.P. 2010 


\section{A CONCORDÂNCIA VERBAL NA REGIÃO NOROESTE DO ESTADO DE SÃO PAULO}

Dissertação de Mestrado apresentada ao Programa de Pós em Linguística e Língua Portuguesa da Faculdade de Ciências e Letras da

Universidade Estadual Paulista "Júlio de Mesquita Filho"- UNESP/Araraquara, como requisito para obtenção do título de Mestre em Linguística e Língua Portuguesa.

Linha de pesquisa: Análise fonológica, morfossintática, semântica e pragmática.

Orientadora: Prof ${ }^{\mathrm{a}} \mathrm{Dr}^{\mathrm{a}}$ Odette Gertrudes Luiza Altmann de Souza Campos.

Bolsa: CAPES.

Data da defesa: 06/05/2010

Membros Componentes da Banca Examinadora:

Presidente e Orientador: Prof ${ }^{\mathrm{a}}$ Dr${ }^{\mathrm{a}}$ Odette Gertrudes Luiza Altmann de Souza Campos UNESP - Campus de Araraquara

Membro Titular: Prof ${ }^{\text {a }}{ }^{\text {a }}$ Rosane de Andrade Berlink

Membro Titular: Profª Dra Ângela Cecília Souza Rodrigues

Membro Suplente: Profa Dra Beatriz de Oliveira Longo

Membro Suplente: Vanice Maria Oliveira Sargentini

Universidade Estadual Paulista

Faculdade de Ciências e Letras

UNESP - Campus de Araraquara 
Dedico esta dissertação aos meus exemplos de vida:

Deus:

o grande responsável por tudo.

\section{Zilmara,}

minha amada mãe, que sempre me mostrou o caminho da educação e da verdade.

\section{$\mathcal{N a t a l}$}

meu amado pai, que sempre me protegeu e me guiou pelos caminhos corretos.

Sempre estimulando-me a dar este grande passo. Estas duas pessoas com muita sabedoria, discernimento, bom senso e dedicação estiveram ao meu lado, encorajando-me nas horas difíceis e aplaudindo-me nos momentos de glória. Obrigada por serem meus pais, fonte de inspiração, apoio e ensino diário. 


\section{AGRADECIMENTOS}

Agradecer a todos que ajudaram a construir esta dissertação não é tarefa fácil. O maior perigo que se coloca para o agradecimento seletivo não é decidir quem incluir, mas decidir quem não mencionar. Então, a todos que, de uma forma ou de outra, contribuíram com sua amizade e com sugestões efetivas para a realização deste trabalho, gostaria de expressar minha profunda gratidão.

Se devo ser seletiva, então é melhor começar do início. Meu maior agradecimento é dirigido a meus pais, Natal e Zilmara, por terem sido o contínuo apoio em todos estes anos, ensinando-me, principalmente, a importância da construção e coerência de meus próprios valores. A paciência infinita e a crença absoluta, na capacidade de realização a mim atribuída, a vibração a cada etapa por mim cumprida, a vibração por cada conquista, a presença sempre constante, nos momentos alegres e nos momentos difíceis, a certeza de que jamais estarei sozinha nessa caminhada que se chama vida, foram, indubitavelmente, os elementos propulsores desta dissertação.

A minhas irmãs Vanessa e Larissa, por fazerem parte da minha história, por terem acreditado em mim e pela valiosa ajuda em diversos momentos.

Ao Leandro, meu companheiro nesta trajetória, que soube compreender, como ninguém, a fase pela qual eu estava passando. Durante a realização deste trabalho, sempre tentou entender minhas dificuldades e minhas ausências. Agradeço-Ihe, carinhosamente, por tudo isto.

Com carinho especial aos meus avós, pelo carinho e pela hospedagem terna inúmeras vezes, aos meus queridos tios e primos, por serem prestativos e bondosos.

Aos meus amigos - Carol, Niguelme, Alexandre, Juliana, Eliane, Beatriz e Paola que partilharam comigo as minhas angústias e sempre me apoiaram nos momentos difíceis. Obrigada pela amizade, pelo amor e pela dedicação.

Minha seleção, no âmbito acadêmico, deve também começar do início. Agradeço em especial a querida professora Odette Gertrudes Luiza Altmann de Souza Campos, por ter me ensinado a arte de pensar o trabalho acadêmico com rigor e disciplina. Suas sugestões que levaram a sucessivas revisões do texto, cujas eventuais falhas, inteiramente de responsabilidade minha, teriam sido mais numerosas não fosse por sua crítica constante e incisiva. Por todo empenho, sabedoria, compreensão e, acima de 
tudo, exigência. Gostaria de ratificar a sua competência, participação com discussões, correções e sugestões que fizeram com que concluíssemos este trabalho.

Incluo, de forma especial, o nome das professoras Rosane de Andrade Berlinck, Silvia Rodrigues Vieira e Cláudia Regina Brescancini, nesta minha lista seletiva. Foi sorte terem cruzado meu caminho acadêmico nesta etapa de conclusão de mestrado. Suas idéias permearam meu trabalho e enriqueceram meu lado linguístico. Serei eternamente grata pelas valiosas contribuições acadêmicas.

À Profa. Dra. Marta Scherre, à Profa. Dra. Beatriz Nunes de Oliveira Longo, à Profa. Dra. Ângela Cecília Souza Rodrigues e à Profa. Dra. Vanice Maria Oliveira Sargentini pela leitura atenta do trabalho e pelas preciosas sugestões.

Aos funcionários da Seção de Pós-Graduação, principalmente ao Domingos e à Rita, pelo trabalho competente, pela dedicação e pelo amor a nós dedicados.

Agradeço à Coordenção de Aperfeiçoamento de Pessoal de Nível Superior, CAPES, pela bolsa concedida durante os anos do curso.

Aos informantes que participaram desta pesquisa, pois sem eles nenhuma dessas páginas estaria completa.

Às escolas estaduais que me receberam de braços abertos, sempre muito prestativas. Em especial ao professor Ademir Pradela, pelas valiosas redações que me emprestou e pelas aulas de português durante todo o ensino fundamental II e ensino médio, um dos grandes responsáveis pela minha escolha acadêmica.

Ao amigo Vítor Mancera, pela valiosa ajuda e por ter disponibilizado as redações de seus alunos do ensino médio.

A todas as pessoas que, direta ou indiretamente, contribuíram para a execução desta Dissertação de Mestrado, em especial aos meus queridos familiares. $E$ àqueles que se foram, que certamente estão olhando por mim: meu padrino e o Bano.

A Deus, força maior que nos impulsiona.

Amo todos vocês. 
"Há fromens que lutam um dia e são bons. Há outros que lutam um ano e são melhores. Há os que lutam muitos anos e são muito bons. Porém, há os que lutam toda a vida. Esses são os imprescindíveis." 


\section{RESUMO}

Este trabalho apresenta um estudo sobre concordância verbal cujo objetivo é o de verificar se o fenômeno em questão se caracteriza como uma regra variável, bem como quais fatores linguísticos e extralinguísticos condicionam essa variação. Para tanto, o escopo do estudo se restringiu à língua falada e escrita pelos moradores da região noroeste do Estado de São Paulo. Utilizaram-se dois corpus para viabilizar a execução da pesquisa, a saber, um pertencente ao IBILCE/ UNESP sob a denominação "O português falado no interior paulista: constituição de um banco de dados anotado para o seu estudo" (PROCESSO FAPESP 03/08058-6), e outro composto por redações escolares de alunos do ensino fundamental I ao ensino médio. Como fatores linguísticos relevantes para nossa análise, destacamos a saliência fônica verbal, o paralelismo formal, a posição do sujeito e a estrutura do sujeito. Como fatores extralinguísticos, a faixa etária e o grau de escolaridade. Utilizamos o programa computacional GOLDVARB-X para realizar a análise quantitativa, cujos resultados mostraram ser a concordância verbal, tanto na escrita quanto na fala, uma regra variável, condicionada principalmente pelo grau de escolaridade dos informantes. Em ambas modalidades, temos $85 \%$ de aplicação da regra, porcentagem que consideramos alta.

Palavras- chave: variação linguística; concordância verbal; língua falada e língua escrita. 


\title{
THE VERBAL AGREEMENT IN THE NORTHWEST OF THE SÃO PAULO STATE
}

\begin{abstract}
This study aims to ascertain whether the verbal agreement is a phenomenon which constitutes a variable rule, and therefore to track the linguistic and extralinguistic factors which would create such a variation. To do so, this scope restricts its scope to the spoken and the written language as it is used by speakers from the northwest of the São Paulo State. Two corpora have been used to make this research feasible, namely, one from IBILCE/UNESP, whose Portuguese title translates as 'The Portuguese spoken in the São Paulo State countryside: the constitution of an annotated database for its study', and another one consisting of pieces of writing by students at either elementary or high school levels. We pay special attention to linguistic factors such as verbal phonetic salience, formal parallelism, the position of the subject as well as to the structure of the subject, which we deem relevant for our analysis. As of extralinguistic factors, we stress the importance of the age group and also of the educational level. We conducted the quantitative analysis using the GOLDVARB-X software, the results of which lead us to figure that the verbal agreement is a variable rule created mainly by the extralinguistic factor concerning the interviewee's level of education, in either the written or in the spoken form. In both situations, the aforementioned rule applies to $85 \%$ of cases, a percentage which we deem to be high.
\end{abstract}

Keywords: linguistic variation; verbal agreement; spoken language; written language. 


\section{LISTA DE GRÁFICOS}


Gráfico 1: Distribuição da população da região de SJRP

Gráfico 2: $\quad$ Número de informantes da AC por cidade.................................. $\quad 55$

Gráfico 3: Porcentagem total de aplicação da regra de CV na modalidade falada.

Gráfico 4: Porcentagem geral de presença/ausência de CV (resultados de Scherre e Naro, 1993)

Gráfico 5: Porcentagem geral de presença/ausência de CV (resultados de Vieira, 1995)....

Gráfico 6: Porcentagem geral de presença/ausência de CV (resultados de Monguilhott, 2009).

Gráfico 7: Aplicação de CV segundo a variável paralelismo formal: comparação entre os resultados de Monguilhott, 2001; de Cardoso, 2005 e de Vieira, 1995

Gráfico 8: Aplicação de CV segundo a variável posição do sujeito: comparação entre os resultados de Monguilhott (2001), de Cardoso (2005), de Vieira (1995) e de Scherre (2005)

Gráfico 10: Aplicação da regra de CV com relação à faixa etária

Gráfico 11: Aplicação de CV segundo a variável faixa etária (Monguilhott, 100 2009)

Gráfico 12: Aplicação de CV segundo a variável faixa etária (Gameiro, 
Gráfico 13: Aplicação de CV segundo a variável escolaridade: contraste entre os resultados de Monguilhott, 2001 e de Rocha Mattos, 2003

Gráfico 14: Contraste entre os resultados encontrados por Cardoso (2005), Vieira (1995) e Naro (1981) segundo a variável saliência fônica: aplicação da regra de CV

Gráfico 15: Percentual geral de presença/ausência de CV

Gráfico 16: Comparação entre os meus resultados gerais de aplicação versus não-aplicação da regra de $\mathrm{CV}$, na modalidade escrita, os de Gameiro (2009) e os de Graciliano da Silva (2009)

Gráfico 17: Aplicação de CV de acordo com a variável escolaridade

Gráfico 18: Gráfico contrastivo entre os nossos resultados, os de Graciliano da Silva (2009) e os de Aquino Silva (1997)..... 


\section{LISTA DE QUADROS}


Quadro 1: Distribuição e identificação dos informantes da Amostra Censo por variáveis sociais

Quadro 2: Composição da subamostra da pesquisa.

Quadro 3: Variável saliência fônica verbal.......................................

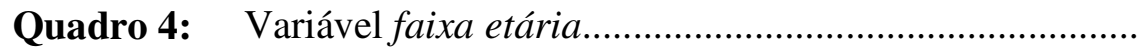

Quadro 5: $\quad$ Variável escolaridade na modalidade falada....................

Quadro 6: Variável escolaridade na modalidade escrita...................

Quadro 7: $\quad$ Variável renda sócio-econômica........................................ 


\section{LISTA DE TABELAS}


Tabela 1: Aplicação da regra - paralelismo formal.

Tabela 2: Aplicação da regra - distância e posição do sujeito.

Tabela 3: Cruzamento entre paralelismo formal oracional e distância 96 e posição do sujeito.

Tabela 4: $\quad$ Aplicação da regra segundo à faixa etária.

Tabela 5: Cruzamento entre paralelismo formal oracional e faixa etária.

Tabela 6: Aplicação da regra - variável escolaridade.

Tabela 7: Cruzamento entre faixa etária e escolaridade.

Tabela 8: Aplicação da regra - saliência fônica

Tabela 9: Cruzamento entre paralelismo formal oracional e saliência fônica.

Tabela 10: Aplicação da regra - estrutura do sujeito.

Tabela 11: Cruzamento entre paralelismo formal oracional e estrutura do sujeito

Tabela 12: Aplicação da regra de CV para a variável sexo.

Tabela 13: Contraste entre os resultados encontrados por nós e por Monguilhott (2009) - aplicação da regra de CV para a variável gênero

Tabela 14: Cruzamento entre paralelismo formal orcaional e sexo......... 
Tabela 15: Aplicação da regra para a variável traço semântico do sujeito.

Tabela 16: Cruzamento entre paralelismo formal oracional e traço semântico do sujeito.

Tabela 17: Aplicação da regra segundo a variável tipo de relato.

Tabela 18: Cruzamento entre paralelismo formal oracional e tipo de relato

Tabela 19: Aplicação da regra segundo a variável renda sócio125 econômica.

Tabela 20: Cruzamento entre paralelismo formal oracional e renda 126 sócio-econômica.

Tabela 21: Aplicação da regra segundo a variável papel semântico do verbo.

Tabela 22: Cruzamento entre paralelismo formal oracional e 129 escolaridade.

Tabela 23: Aplicação da regra - escolaridade...

Tabela 24: Aplicação da regra - paralelismo formal.

Tabela 25: Cruzamento entre escolaridade e paralelismo formal.

Tabela 26: Aplicação da regra - saliência gráfica.

Tabela 27: Cruzamento entre escolaridade e saliência gráfica.

Tabela 28: Aplicação da regra - posição do sujeito. 
Tabela 29: Cruzamento entre posição do sujeito e escolaridade...............

Tabela 30: Aplicação da regra de $\mathrm{CV}$ segundo a variável pronome 148 pessoal

Tabela 31: Cruzamento entre escolaridade e pronome pessoal.

Tabela 32: Aplicação da regra segundo a variável classe gramatical do núcleo do sujeito

Tabela 33: Cruzamento entre escolaridade e classe gramatical do núcleo do sujeito. 


\section{LISTA DE ABREVIATURAS E SIGLAS}

$\mathrm{AC}-$ Amostra Censo

ALIP - Amostra Linguística do Interior Paulista

CV - Concordância verbal

GPGE - Grupo de Pesquisa em Gramática Funcional

PB - Português brasileiro

SN - Sintagma nominal 
SUMÁRIO 


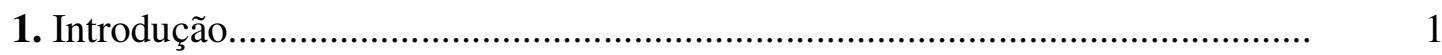

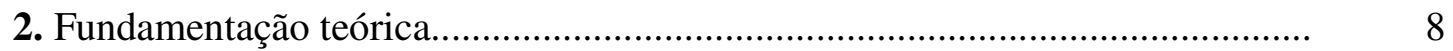

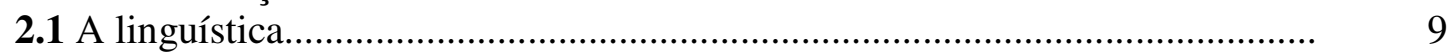

2.2 A sociolinguística........................................................................... 15

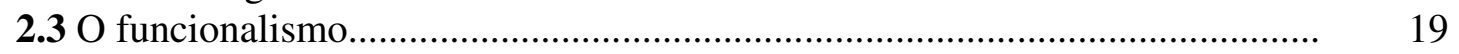

2.4 A norma linguística................................................................................ 21

2.5 Variação e mudança...................................................................................... 26

3. O fenômeno em estudo

3.1 Categoria de número no português................................................................ $\quad 30$

3.2 A concordância verbal segundo a Gramática Tradicional.............................. 31

3.3 A concordância verbal segundo a Gramática Funcional................................... 38

3.4 Concordância verbal: da fala para a escrita.................................................... 42

4. Procedimentos metodológicos........................................................................... 45

4.1 Sobre a cidade de São José do Rio Preto........................................................... 47

4.2 Sobre a constituição do corpus da modalidade falada....................................... $\quad 50$

4.3 Composição da subamostra da modalidade falada........................................... 56

4.4 Composição do corpus da modalidade escrita................................................ 58

4.5 Variáveis linguísticas e extralinguísticas.......................................................... 61

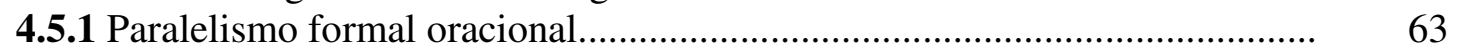

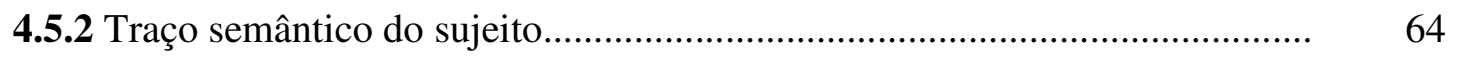

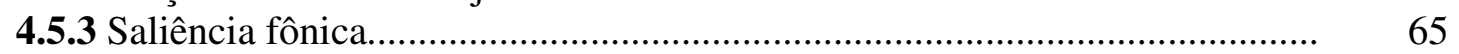

4.5.4 Estrutura do sujeito..................................................................................... 68

4.5.5 Distância e posição do sujeito com relação ao verbo..................................... 69

4.5.6 Papel semântico do verbo.......................................................................... $\quad 70$

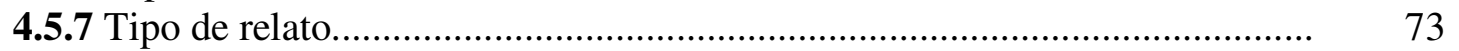

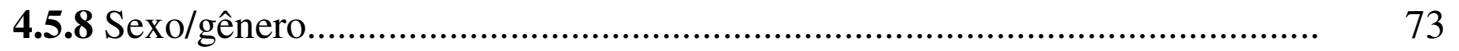

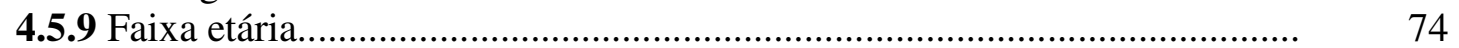

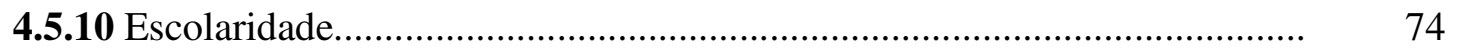

4.5.11 Renda sócio-econômica............................................................................. 76

5. Análise dos dados da modalidade falada......................................................... $\quad 79$

5.1 Paralelismo formal oracional......................................................................... $\quad 85$

5.2 Variável distância e posição entre sujeito e verbo............................................. 89

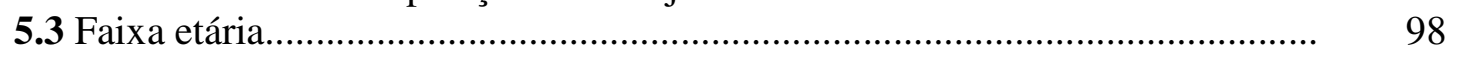

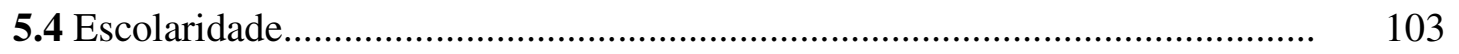

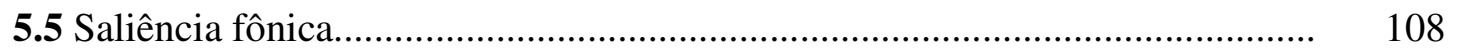

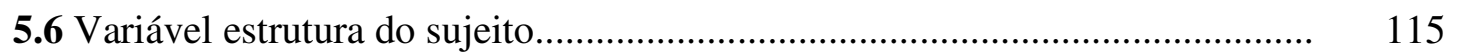

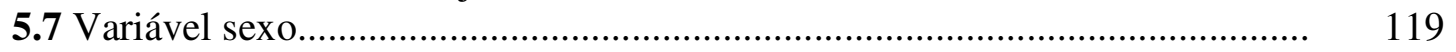

5.8 Variável traço semântico do sujeito..................................................................... 121 
5.9 Variável tipo de relato

123

5.10 Variável renda sócio-econômica.............................................................. 125

5.11 Variável papel semântico do verbo............................................................... 127

6. Análise dos dados da modalidade escrita.......................................................... 131

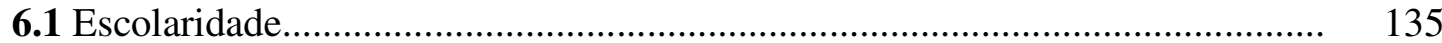

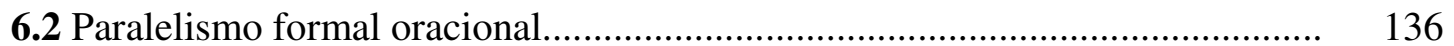

6.3 Saliência fônica/gráfica.................................................................................. 139

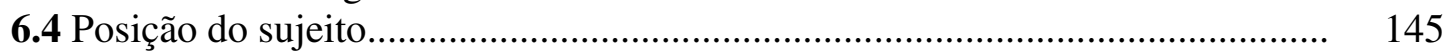

6.5 Variáveis excluídas....................................................................................... 148

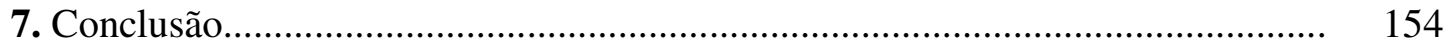

8. Referências bibliográficas................................................................................. 160 


\section{INTRODUÇÃO}

Este trabalho descreve e analisa a concordância existente entre sujeito e verbo, tendo como amostra da modalidade falada o projeto IBORUNA, pertencente ao IBILCE/UNESP, e, como amostra da modalidade escrita, redações escolares. Ambas as amostras serão analisadas sob a perspectiva da Sociolinguística Variacionista.

A grande quantidade de trabalhos que envolvem a concordância verbal reflete sua importância para os estudos linguísticos e sua fecundidade de campo de análise. Acreditamos que compreender a variação e observar seus reais contextos de uso pode ser útil, principalmente, em explicações em sala de aula.

Objetivamos com essa pesquisa analisar, tanto na modalidade falada quanto na modalidade escrita, como se dá a realização da regra variável de concordância verbal; testar algumas das mais relevantes variáveis linguísticas e extralinguísticas encontradas em outros trabalhos que também se propuseram a estudar a concordância verbal; avaliar se o fenômeno da concordância verbal é regido por apenas uma variável ou se há uma confluência de motivações; após compararmos nosso trabalho com outros trabalhos acerca da CV, perceber o fluxo que este fenômeno variável está seguindo.

Neste trabalho, nosso foco é a língua em seu funcionamento, tanto falada quanto escrita. Na modalidade falada, estudamos a língua utilizada por pessoas em situações de menor grau de formalidade, onde as pessoas, depois de um curto tempo de entrevista, fazem pouco monitoramento da fala. Já, no caso da modalidade escrita, sabemos que há um maior monitoramento das regras gramaticais, mas, de todo modo, queremos observar até que ponto a concordância verbal também se manifesta em tal modalidade. 
Nossa pesquisa compreende a descrição e análise dos padrões de concordância de número do verbo com sujeitos de $3^{\text {a }}$ pessoa do plural, sendo este um pronome pessoal do caso reto ou não, encontrados nas variedades do português falado e escrito por pessoas de diferentes faixas etárias, diferentes níveis de escolaridade e diferentes níveis sócio-econômicos residentes na cidade de São José do Rio Preto, interior do Estado de São Paulo.

A variável concordância verbal é dependente, pois o emprego das variantes não é aleatório, mas influenciado pelas variáveis independentes de natureza estrutural ou social, isto é, internas ou externas à língua. As variáveis internas são os fatores de natureza fono-morfo-sintática, os semânticos, os discursivos e os lexicais. As variáveis externas são as que reúnem os fatores inerentes ao indivíduo, são, portanto, sociais.

Há duas variantes para a marcação de plural no português do Brasil: a variante [S] é padrão, conservadora e de prestígio, já a variante [Ø], por outro lado, é inovadora, estigmatizada e não-padrão.

Devido ao fato de a variação na concordância, tanto verbal quanto nominal, estar no centro de uma discussão sobre as origens do português brasileiro, demonstrando o quão instigante é o fenômeno da regra de concordância verbal, apresentamos a seguir as duas grandes teorias acerca da origem da variação no fenômeno da concordância, com o objetivo de esclarecer um dos motivos que nos levaram a estudar tal fenômeno linguístico. Segundo Lucchesi (2006), muitas das características atuais do português brasileiro, sobretudo de suas variedades populares e rurais, refletem processos de variação e mudança provenientes do contato do português com as línguas dos escravos africanos trazidos para o Brasil. As marcas mais evidentes desse processo de 
transmissão linguística irregular ${ }^{1}$ pelo qual o português brasileiro passou, devido ao contato amplo com as línguas indígenas e, sobretudo, com as línguas africanas, devem ter desaparecido nas ultimas três ou quatro décadas, em função do processo de nivelamento linguístico ocorrido a partir da vasta difusão dos modelos culturais e linguísticos dos grandes centros urbanos, sobretudo pelos meios de comunicação de massa, mas também pelo deslocamento populacional e pelo sistema público de educação. Em outras palavras, Lucchesi (2006) defende a idéia de que o contato entre línguas desencadeou importantes mudanças na estrutura das variedades da língua portuguesa que viriam a se desenvolver nos segmentos da base da sociedade brasileira, através do que se denominou processo de transmissão linguística irregular.

Desde os primórdios da formação da sociedade brasileira, a mestiçagem entre raças tem criado as condições para que os padrões de fala de escravos e mestiços, moldados no contato do português com as línguas africanas, insinuem-se na fala dos segmentos sociais superiores, afetando os padrões de concordância verbal e nominal do português brasileiro.

O caso da variação na concordância verbal, que se teria originado no processo de transmissão difundiu tanto que, hoje, se tornou um fenômeno que se verifica em todos os extratos da sociedade brasileira, havendo apenas uma diferença de frequência na variação que ainda separa os segmentos de maior poder aquisitivo e melhor nível de escolaridade, da população pobre analfabeta ou de pouca instrução. Entretanto, muitos

\footnotetext{
${ }^{1}$ A transmissão linguística regular, segundo Lucchesi (2006), processa-se entre crianças, a partir da fase de socialização, na base de uma dada amostra de fala suscetível de uma análise. De modo contrário, a transmissão linguística irregular se dá entre adultos com base de fala não suscetível de uma análise. A aquisição linguística processada entre crianças para criar sua primeira língua não comporta noções de caos ou insuficiência, uma vez que a comunicação entre elas é funcional.
} 
foram os estudiosos que negaram o papel relevante da crioulização, proposto por Lucchesi.

Naro \& Scherre (2007) definem crioulização como sendo

difícil de delimitar, porque o termo nunca teve uma única definição amplamente aceita no campo da linguística. (...) há primeiro um estágio pidgin ${ }^{2}$, em que um sistema verbal de comunicação, que não é língua nativa de nenhum grupo, é usado para a transmissão de informação entre falantes que não têm qualquer língua natural em comum. Normalmente, esse estágio envolve um vocabulário que se origina predominantemente de uma língua específica, normalmente denominada de língua base. A falta de norma gramatical estável é inerente à noção de pidgin, tendo em vista que, nessas circunstâncias, qualquer estrutura que efetivamente funcione no processo de comunicação é aceitável. (...) o segundo estágio do processo, a crioulização, ocorre quando o pidgin se torna a língua nativa de um segmento da comunidade. (...) (Naro \& Scherre, 2007, p. 51).

Segundo Guy (1981 e 1989), após a perda das regras de concordância, decorrente do processo prévio de crioulização, estaria em curso um processo de (re)aquisição dessas regras a partir dos contextos em que elas fossem mais salientes, caracterizando assim um processo de descrioulização, pois o processo de mudança se daria em direção à língua alvo: o português culto.

Naro e Scherre (1993) procuram demonstrar que as mudanças que afetaram a concordância nominal e verbal no Brasil teriam as suas origens, não na simplificação operada pelo contato entre línguas, mas em mudanças fonéticas que se teriam iniciado em Portugal, sob a ação das forças de uma deriva românica, que se define como o fato de que a língua se move ao longo do tempo num curso que lhe é próprio.

\footnotetext{
${ }^{2}$ Segundo Naro \& Scherre (2007), pidginização é a criação de um sistema linguístico por adultos. O pidgin surge a partir de um contato entre grupos populacionais para propósitos definidos, tais como trocas comerciais, em qualquer contexto em que as pessoas não dispõem de outro meio verbal comum de comunicação.
} 
Acreditamos que o português popular evoluiu pelo processo normal da deriva linguística interna, cuja simplificação morfológica está presente na deriva histórica do português desde as suas origens mais remotas no indo-europeu, no qual ganhou força a idéia de que o enfraquecimento fonético do segmento nasal final - $m$ de verbos estaria embutido na deriva secular da língua portuguesa, conduzindo a uma erosão do morfema de plural nas formas verbais.

Naro e Scherre (2007) afirmam que características morfossintáticas e fonológicas do português brasileiro, atualmente envoltas em estigma e preconceito social, são heranças românicas e portuguesas arcaicas e clássicas, e não modificações mais recentes advindas das línguas africanas. De modo que a visão da concordância variável no Brasil como sendo um fenômeno radicalmente não-europeu é refutada pelos resultados de Naro e Scherre (2007), que mostraram que a concordância é variável tanto no português europeu falado quanto no português medieval escrito, exibindo as mesmas características estruturais fundamentais encontradas no português moderno falado no Brasil.

Resumindo, há basicamente duas correntes de pensamento com relação à origem da falta variável de concordância, bem como de outros fenômenos variáveis no português não-padrão do Brasil. Uma delas considera que o português do Brasil é radicalmente diferente do português europeu. Sob essa perspectiva, a principal causa da divergência em relação às linhas de desenvolvimento europeu é a presença maciça de pessoas de origem africana no Brasil, cujas línguas de origem teriam influenciado o português do Brasil de base lexical portuguesa.

A outra visão é que, nesse aspecto, a variação na concordância verbal tem origem na antiga deriva secular das línguas indo-européias em geral, e das línguas 
românicas em particular, em direção a uma gramática com menos marcas de flexão. As estruturas variáveis poderiam ter existido tanto em Portugal quanto no Brasil, mas talvez em épocas e em graus diferentes. O português moderno do Brasil é o resultado natural da deriva secular inerente na língua trazida de Portugal, indiscutivelmente exagerada no Brasil pela exuberância do contato de adultos, falantes de línguas das mais diversas origens, e pela nativização dessa língua pelas comunidades formadas por esses falantes. Haveria, então, uma confluência de motivações, com umas tendências mais fortes no início do processo histórico seguinte do que as outras.

Nosso trabalho está estruturado da seguinte forma: na segunda seção, apresentamos a fundamentação teórica, na qual se alicerça nossa investigação, a saber: a história da linguística e os principais pontos da teoria sociolinguística. $\mathrm{Na}$ terceira seção, apresentamos a concordância verbal segundo a gramática normativa. Já na quarta seção, apresentamos questões a respeito do corpus, da região da pesquisa; abordamos, também, as variáveis linguísticas e extralinguísticas analisadas nessa pesquisa. Na quinta seção, analisamos os resultados dos cálculos das variáveis linguísticas e extralinguísticas geradas pelo GOLDVARB-X, para a modalidade falada. A sexta seção versa sobre os resultados gerados pelo GOLDVARB-X, para a modalidade escrita e, na última seção, trazemos o encerramento, as conclusões dessa pesquisa de cunho variacionista. 


\section{FUNDAMENTAÇÃO TEÓRICA}

A língua falada é um instrumento de comunicação dos homens na sociedade. Homem e sociedade estão vinculados, de modo que não há homem sem sociedade e sociedade sem homem.

Falar que um indivíduo se comunica com outros, é falar que emprega meios para transmitir e fazer aparecer em sua fala o que tem em sua mente. A linguagem verbal marca o homem enquanto indivíduo atuante na sociedade.

A linguagem serve para o exercício da sociabilidade, que condiciona todas as ações em sociedade. Essa linguagem se apresenta com um grande número de línguas, subdivididas geralmente em dialetos e falas, que se formam e evoluem em condições variadas. E diante da heterogeneidade cultural, social e econômica, o Brasil é a nação da diversidade em qualquer aspecto que se queira considerar.

Segundo Marcel Cohen (1974), a linguagem é adquirida em torno de um dado grupo social, que tem sua individualidade linguística. As línguas evoluem lentamente, se reafirmando, se modificando.

Como sabemos, a língua é intrinsecamente heterogênea, múltipla, variável, instável e está sempre se modificando. A língua é um processo, um fazer-se permanente e jamais concluído. É uma atividade social, um trabalho em equipe, empreendido por todos os seus falantes, cada vez que eles se propõem a interagir através da fala ou da escrita.

Pensamos que a todo trabalho subjaz uma teoria, portanto, ao trabalharmos com a variação da concordância verbal na região noroeste do Estado de São Paulo, devemos também trabalhar com uma teoria que dê suporte para a análise dos dados. 
Como já foi dito, a teoria que norteará nosso trabalho é a Teoria da Variação Linguística, selecionada a partir do nosso objeto de estudo.

O objetivo desta seção é apresentar algumas das principais idéias da Sociolinguística Laboviana por meio de considerações gerais sobre tal teoria, porém antes de iniciarmos tais considerações, acreditamos que uma singela exposição sobre as origens da Linguística e sobre o Funcionalismo possa auxiliar o esclarecimento de algumas questões teóricas, além de mostrarmos o percurso que a Linguística traçou até chegar na área da Sociolinguística.

\subsection{A LINGUÍSTICA}

Segundo Martelotta (2008), a linguística surge, como disciplina científica, no século XIX, porém o interesse pela linguagem data da Antiguidade. Em Aristóteles e Platão, encontramos rudimentos de uma teoria das partes de um discurso, construída com motivações lógico-filosóficas, mais tarde desenvolvidas pelos lógicos medievais.

Os gramáticos alexandrinos propuseram uma gramática do grego de caráter normativo-prescritivo. A gramática pode então ser considerada como elemento que se apresentava como um modo de ensinar a ler e a escrever corretamente.

Ainda referente à Antiguidade, o estudo das formas das palavras tinha a finalidade de estabelecer que som deveria ser produzido nos cânticos sagrados, isso porque o interesse religioso, na Índia, levou a estudos bastante rigorosos de aspectos fonológicos do sânscrito. Esses estudos descritivos do som podem ser encontrados na gramática de Panini, um precursor dos estudos estruturais do século XX.

Bréal, no século XIX, considerava que os estudos sobre a linguagem se caracterizavam por levar em conta os aspectos da significação, estudavam-se as 
formas das palavras, tal como na tradição dos hindus. Dessa forma, desenvolveu-se o método comparativo de estudo das línguas, que consistia em se comparar sistematicamente seus sistemas fonéticos, suas estruturas gramaticais e seu vocabulário, a fim de demonstrar características comuns, as quais poderiam atribuirIhes grau de parentesco.

Antecedida por tais estudos é assim que, no início do século XIX, se constitui a linguística, apresentando como objeto de estudo a comparação linguística. Para tratar desse objeto, a linguística adota o método comparativo, que consiste em encontrar conjuntos de formas cognatas ou supostamente cognatas, em línguas ou dialetos a serem comparados, e extrair conjuntos de correspondências fonéticas. É a partir desses conjuntos que se reconstrói uma série de fonemas da proto-língua, que formam as palavras reconstruídas e são posteriormente comparadas com as das línguas derivadas.

No entanto, algumas críticas ao método comparativo começaram a ocorrer, propiciando ainda mais o aparecimento de outras ciências da linguagem. O método comparativo pressupunha um total afastamento das comunidades de fala e, ainda, uma comunidade de fala totalmente uniforme, o que não ocorria, segundo os críticos.

Segundo Guimarães e Orlandi (2006), no decorrer do século XX, as ciências da linguagem tiveram desenvolvimentos particulares. Muitas vertentes se estabeleceram de modo consistente nos estudos linguísticos.

No século XX, observamos as novas maneiras de se pensar acerca da linguagem. Surge, por exemplo, Saussurre que considerava a língua como único e verdadeiro objeto da linguística. Para ele, tudo que estivesse fora da língua deveria ficar fora dos estudos da linguística, como, por exemplo, o aspecto social da linguagem. 
Segundo Costa (apud Martelotta 2008, p. 113), o estruturalismo apresentava algumas dicotomias, vejamos a principal: langue (sistema linguístico) em oposição à parole (comportamento linguístico) e forma em oposição à substância. Segundo Saussurre, ainda que um enunciado seja produzido de diversas maneiras, sua forma (estrutura) permanecerá a mesma. Para o linguista, a língua é um sistema de signos, em que esses elementos estão definidos pela oposição a outros signos do sistema. Ele considera a língua como um sistema fechado, que deve ser estudado em si mesmo, sem considerar nada que lhe seja exterior. Conforme suas idéias, tudo o que não fizesse parte do sistema, como, por exemplo, a fala, deveria ser excluído dos estudos linguísticos.

Saussurre também abordou a linguística sincrônica e a diacrônica, sustentando que a linguística sincrônica deveria lidar com a estrutura do sistema de uma língua em um dado momento, enquanto a linguística diacrônica deveria ser atomística, ou seja, deveria se preocupar com o desenvolvimento histórico de elementos isolados.

Após a difusão dos preceitos estruturalistas saussurreanos, importantes escolas de linguística surgiram na Europa, a Escola de Praga, com representantes como Nikolai Sergeievitch e Roman Jakobson, e a Escola de Copenhague (ou glossemática ou ainda conhecida também como Escola de Londres), com representantes como Louis Hjelmslev e John Rupert Firth.

Surge também, nesse mesmo século, a figura de Avram Noam Chomsky que publica, em 1957, o livro Syntatic Structures, que desencadeou a chamada Gramática Gerativa. O linguista levava em conta a diferença entre os níveis estruturais "superficial" e "profundo", privilegiando o nível subjacente das estruturas. 
Chomsky traçou uma distinção fundamental, assim como a dicotomia saussurreana, referindo-se à competência (conhecimento das regras de uma língua) e ao desempenho (uso efetivo da língua em situações reais). Para ele, era tarefa do linguista ocupar-se apenas da competência, pois nenhum corpus daria conta de todas as situações possíveis de uso.

O linguista propunha descobrir as realidades mentais subjacentes, ou seja, nossa capacidade psicológica. A linguística não deveria limitar-se somente à descrição da competência, mas também oferecer uma gramática capaz de abarcar toda a natureza da linguagem humana, os chamados "universais linguísticos".

Chomsky, como Saussurre, insiste na homogeneidade do objeto da linguística. Como Saussurre, ele busca a homogeneidade na noção de estrutura. Porém, diferentemente de Saussurre, Chomsky entende a estrutura como um conjunto de regras, dando um caráter dinâmico à noção de estrutura, em oposição ao caráter estático, sistêmico, da estrutura saussurreana.

Para Chomsky, as crianças possuem uma herança genética, uma teoria linguística que especifica a forma da gramática de uma língua humana possível, o que permite à criança superar a "pobreza dos dados linguísticos", já que há uma deficiência dos dados aos quais ela é exposta no processo de aprendizagem, o que também permite à criança selecionar dentre as gramáticas possíveis, aquela que seja mais adequada aos dados disponíveis que ela tem.

Chomsky escolhe a competência como objeto da linguística, excluindo do domínio da disciplina, consequentemente, todos os fatos do desempenho, agindo do mesmo modo que Saussurre; além do mais, a distinção competência/desempenho tem o mesmo papel homogeneizante que a distinção saussurreana langue/parole. 
E a partir dessas idéias, em oposição à vertente estruturalista e à gerativista, temos, mais recentemente, os funcionalistas, que veem na língua uma atividade social, sujeita à pressão da ideologia. Com o decorrer do tempo, alguns linguistas passaram a contestar alguns conceitos estruturalistas, pois o papel do sujeito não podia ser negligenciado em uma interação verbal. A linguagem é, antes de tudo, uma característica humana, e, para ser descrita, precisa fazer referência à fala e aos diferentes papéis assumidos pelos falantes no processo de interação verbal. Essa visão é, claramente, oposta à visão saussurreana que via a língua como um sistema fechado que se importava somente com a estrutura em si.

Ainda no século $X X$, houve um aumento da interdisciplinaridade, e assim uma intersecção dos estudos linguísticos com outras ciências como a filosofia, a sociologia, a antropologia, a psicologia, a neurociência, a semiologia, etc.

Traçando um panorama de tudo o que foi tratado, até o momento, chega-se à conclusão de que não há um objeto natural anteriormente definido para ser investigado. Pelo contrário, cada teoria recorta o mundo dos fenômenos de forma diferente e, dessa maneira, constitui o seu objeto de estudo.

Cada teoria delimita um objeto observacional, uma porção da realidade que constitui seu objeto de estudos. Essa porção poderá ser puramente linguística, ou poderá se constituir de elementos linguísticos acoplados a seu contexto de produção, situação histórica, conjunto de conhecimentos dos falantes que os empregam.

De todo modo, não devemos comparar uma teoria com outra teoria, ou até mesmo dizer qual seria a melhor perspectiva teórica a ser adotada, pois cada teoria tem objetos de estudo diferentes, e, por isso, diferentes pressupostos, objetivos e metodologia. Cada uma pode contribuir para o progresso da outra e ambas podem 
articular-se na explicação da interação entre representações mentais e processamento linguístico. A depender do fenômeno que se estuda, devem-se fazer recortes e, por isso, adotar um paradigma ou outro, por uma questão de pertinência entre o fenômeno a ser estudado e a teoria que melhor se adéqua a esse recorte.

É importante não perdermos de vista que não há um paradigma correto a ser seguido, não há como compará-lo para saber qual é melhor ou pior. Como já postulava Saussure "o ponto de vista cria o objeto". Assim, ao invés de tentar se excluir, uma teoria deveria complementar a outra.

Uma teoria linguística não é, de forma alguma, excludente da outra, ou seja, ao se assumir que um linguista faz a opção por um caminho, isso não quer dizer que ele não possa considerar algumas premissas de outra teoria, já que ambas focalizam a linguagem.

Após essa breve exposição, notamos que a maneira de olhar a linguagem se modificou ao longo da história da linguística, e uma das grandes mudanças foi a inclusão do aspecto social nos estudos linguísticos.

As implicações que essa inclusão da esfera social teve para os estudos linguísticos foram significativas, na medida em que quase todas as teorias consideram a relação língua e sociedade, mesmo não sendo seu objeto de estudo.

\subsection{A SOCIOLINGUÍSTICA}

Segundo Pagotto (2006), nos anos 60, novos movimentos teóricos inseriam o funcionamento social como parte do funcionamento linguístico, abalando os alicerces do estruturalismo. Várias abordagens linguísticas começaram então a relacionar o corpo da língua com seu exterior, a linguística com o social. 
A sociolinguística surgiu nos Estados Unidos em meados da década de 1960, quando muitos cientistas da linguagem observaram que não era mais possível estudar a língua sem considerar a sociedade em que ela era falada. William Labov foi o linguista que impulsionou o estudo da variação e da mudança na perspectiva sociolinguística, com sua pesquisa sobre o inglês falado na ilha Martha's Vineyard, no estado de Massachusetts, nos Estados Unidos. Ele demonstrou a possibilidade da variação linguística ser objeto plausível de sistematização. Pela primeira vez alguém conseguiu destacar o papel preponderante dos fatores sociais na explicação da variação linguística. Em 1964, após o término de sua pesquisa sobre a estratificação social do inglês em Nova York, ele estabeleceu um modelo de descrição e interpretação do fenômeno linguístico no contexto social de comunidades urbanas, e a esse modelo deu-se o nome de Sociolinguística Variacionista ou Teoria da Variação.

Labov (1972) desmistificou, também, a idéia da língua homogênea e de que a heterogeneidade era impossível de ser sistematizada. Passou a conceber a língua com suas singularidades e peculiaridades. Adotamos a maneira de falar conforme o local em que estamos, a localidade geográfica em que nos inserimos e a situação em que estamos, por exemplo, tensa/distensa.

Segundo Labov (1972), os fatos da língua são condicionados por fatores extralinguísticos, como classe social, idade, sexo/gênero, entre outros, em constante estado de mudança. Sendo a língua heterogênea, a relação social e a interação dos locutores dentro de situações específicas fixam-se como fatores de intensa relevância para determinarem as variantes linguísticas de certa comunidade linguística. 
A variedade padrão que define o modo "correto" de falar acaba, muitas vezes, por disseminar a idéia errônea de que as outras variedades linguísticas, destoantes da variedade padrão, são "inferiores”.

Compete à análise sociolinguística explicar a inserção ou encaixamento de uma variável no sistema de relações sociais e linguísticas de uma comunidade.

Conforme salienta Mollica (2003), uma das principais ideias da sociolinguística é a de que a língua possibilita, em vários lugares estruturais ou lexicais, a escolha da utilização de uma forma linguística ao invés de outra, resultando em inúmeros lugares no processo de variação, o que não significa que a língua seja assistemática, pois até mesmo na variação encontramos sistematicidade. A própria estrutura linguística nos mostra as possibilidades que podem ou não variar, por exemplo, o /S/ em final de sílaba pode aparecer ou não nos sintagmas nominais presentes em uma dada frase, mas não pode variar se estiver em início de palavra, ou seja, ele sempre será pronunciado.

No momento da enunciação, o falante escolhe, em função da relação entre falante/ouvinte, as formas linguísticas que vai usar, revelando quem ele é e o que deseja do seu interlocutor. Isso nos deixa claro que, no interior de uma determinada língua, há uma série de condições que determinam a opção por uma ou outra forma variante. É a partir da interação, por meio de uma variação que se faz presente em uma rede de comunicação, que gira em torno de um eixo sistêmico, que faz com que os falantes possam se comunicar e ser compreendidos, mesmo havendo variação linguística. Isso porque os falantes compartilham os mesmos valores com relação à língua, devido às regras linguísticas, que são impostas dentro da comunidade de fala.

Segundo Labov (1972), a variação pode ou não indiciar mudanças, mas não há mudança sem variação que a preceda. A análise da variação linguística pode, além de 
revelar uma regularidade sistemática, detectar a possibilidade de uma mudança linguística em curso.

O avanço da sociolinguística no Brasil, segundo Mattos e Silva (2004), orientouse para os estudos da variação social urbana e começou a revelar a complexidade da heterogeneidade social do português brasileiro.

A sociolinguística vê a variação não como um problema, mas sim como uma qualidade constitutiva do fenômeno linguístico. Sem variações, teríamos uma gramática normativa que daria conta de todas as construções e isso bastaria. Haveria uma redução do fenômeno, haveria um estudo apenas do formal e do estruturado.

Modos de dizer caracterizam uma determinada região, por exemplo, determinados traços linguísticos de natureza dialetal geográfica, tendem a marcar profundamente os falantes, como é o caso do ' $r$ ' retroflexo, mais conhecido como /R/ caipira, que é uma das marcas mais perceptíveis da nossa região.

O conjunto das regras sociais determina funcionamentos linguísticos específicos de cada região, de modo que os falantes adquirem as variedades típicas da sua região. A variação social se relaciona com um conjunto de fatores que têm a ver com a identidade dos falantes dentro da comunidade de fala, como, por exemplo, a idade, o sexo, a classe social, a religião, a profissão, o contexto social e a escolaridade.

Segundo Weinreich, Labov e Herzog (2006), o fato de que as línguas mudam, por exemplo, nos faz pensar que hoje convivemos com algumas estruturas que possivelmente daqui a algum tempo não serão mais usadas. Um fenômeno que caracteriza um dado dialeto pode ser alterado com o decorrer do tempo. Então a mudança deve ser vista como um dos resultados possíveis de um processo de variação. 
A mudança linguística pode inserir novas formas, anulando formas "antigas" ou, ainda, tais formas podem conviver lado a lado.

Em suma, toda língua é adequada à comunidade que a utiliza, é um sistema completo que permite a um povo exprimir o mundo físico e simbólico em que se vive. Não há línguas inferiores, nem variedades linguísticas inferiores. A língua é um dos componentes do sistema cultural de cada povo. Língua e sociedade estão indissoluvelmente emaranhadas, entremeadas, uma influenciando a outra, uma formando a outra.

Concluindo, a sociolinguística não aceita a visão da variabilidade como um fato aleatório, insiste na necessidade de um controle sistemático e empírico dos fatores estruturais, internos e sociais que motivam o uso de uma ou outra variante. Tal variação está intrinsecamente relacionada a fatores de ordem social e cultural. Assim sendo, a abordagem sociolinguística, assim como a abordagem funcionalista, se preocupa, principalmente, em descrever e explicar o uso da língua, tendo como ponto de partida as interações verbais dos indivíduos em circunstâncias reais.

\subsection{O FUNCIONALISMO}

De acordo com Cunha (apud Martelotta 2008, p. 159), o funcionalismo preocupase com as relações da língua em diversas modalidades de interação social. Os funcionalistas frisam a importância do papel do contexto (social) na compreensão linguística. Sendo assim, os funcionalistas veem a linguagem como um instrumento de interação social que estabelece um objeto de estudos baseado na interação verbal real.

A linguagem é uma ferramenta com formas que se adaptam às funções que são, predominantemente, comunicativas. Há uma busca em se explicar os fenômenos 
linguísticos por meio das relações sócio-interacionais entre falante e ouvinte e seus conhecimentos pragmáticos.

A teoria funcionalista busca meios e princípios por meio dos quais se possam desenvolver gramáticas funcionais de línguas particulares, especificando, mediante um conjunto de regras, todas as expressões linguísticas.

Segundo Neves (1997), a gramática funcional considera a capacidade que as pessoas têm de, além de codificar e decodificar expressões, usarem e interpretarem as expressões de maneira intencional. A linguagem serve para vários propósitos, além de ser uma atividade cooperativa entre falantes reais que pragmatizam o componente sintático-semântico, fato que explicita mais uma vez que os funcionalistas se preocupam com as relações entre a língua e a interação social.

Podemos afirmar, por exemplo, que quando estudamos a concordância verbal presente na fala dos usuários de determinada língua, estamos adotando os pontos de vista funcionalista e sociolinguístico na medida em que tencionamos perceber como agem os usuários de uma língua diante da variabilidade linguística, em outras palavras, como os falantes se entendem a partir de regras linguísticas institucionalizadas que perpassam o processo de interação verbal dotado de regras pragmáticas.

A gramática funcional, ao indicar a teoria da organização gramatical, busca, junto a dados oriundos da interação social, descrever e explicar a língua pragmaticamente.

A sintaxe não pode ser observada como um objeto autônomo em relação à organização da linguagem, mas, sim, como um componente vinculado à semântica e à pragmática que, por sua vez, também apresentam grau de dependência umas das outras. 
A gramática deve tentar explicar suas regras em termos de sua funcionalidade com relação ao modo como são usadas, para atingir o propósito desses usos.

\subsection{A NORMA LINGUÍSTICA}

Neste capítulo, discorreremos a respeito da norma linguística. Sabemos que uma língua é constituída por um conjunto de variedades, devido a esta heterogeneidade linguística surgiu a necessidade de se estipular uma norma que fosse comum a todos. No entanto, a situação era mais complexa, pois sabemos que uma comunidade linguística se caracteriza por um conjunto de normas e não apenas por uma única norma, isso porque essa diversidade correlaciona-se com a própria rede de relações sociais $^{3}$ que se estabelecem no interior de cada comunidade linguística, na qual, muitas vezes, o indivíduo adapta a sua fala à fala do seu interlocutor, pois sabemos que toda estrutura linguística caracteriza-se como um universo de variedades expressivas, de formas alternativas que podem e devem ser escolhidas pelo falante.

Segundo Faraco (2002), foi, na Antiguidade Clássica, que surgiu a mais importante consequência social da variação linguística, a noção de "erro" e, juntamente com ela, o preconceito contra as camadas sociais que falam de um modo diferente do previsto pela norma-padrão.

Coseriu (1980) afirmava que uma norma não corresponde ao que se pode dizer, mas ao que já se disse e tradicionalmente se diz na comunidade em questão. Sendo assim, norma é um determinado conjunto de fenômenos linguísticos costumeiros,

\footnotetext{
${ }^{3}$ As redes sociais são definidas por Milroy (2002) como os relacionamentos criados pelas pessoas para suprir as dificuldades da vida cotidiana. Tais redes podem variar de um indivíduo para outro e ser constituídas por ligações de diferentes tipos de intensidades. Chambers (1995) indica que os elementos que enriquecem as redes são basicamente os mesmos em todo lugar, sejam eles, o grau de parentesco, a ocupação (como o ambiente de trabalho) e a amizade.
} 
habituais em uma determinada comunidade de fala. Para o linguista, "a norma abrange fatos linguísticos efetivamente realizados e existentes na tradição" (Coseriu, 1980, p. 123).

Faraco (2008) distingue norma culta de norma-padrão, pois, para o linguista, norma culta é a variedade que os letrados usam em situação mais monitorada de fala e escrita. A norma culta é recorrente em dados segmentos sociais, em situações mais monitoradas, além de apresentar um grande prestígio perante a sociedade. As variedades cultas, tanto na modalidade falada quanto na escrita, são manifestações reais da língua. Em outras palavras, "a expressão norma culta designa o conjunto de fenômenos linguísticos que ocorrem habitualmente no uso dos falantes letrados em situações mais monitoradas de fala e escrita" (Faraco, 2008, p. 73).

A norma-padrão estimula um processo de uniformização linguística, uma tentativa de homogeneizar a sociedade, tornando-a unificada. É uma norma idealizada, uma vez que se trata de formas linguísticas tomadas como um modelo linguístico ideal, de modo que falar em norma-padrão é pensar em gramática da língua, pois é a única que concebe a língua como homogênea, visando um padrão absoluto de correção.

Segundo Bagno (2007), historicamente, a norma-padrão tem sido um instrumento político de dominação e de exclusão. Ela sempre fez parte de um projeto autoritário de manutenção do poder nas mãos de uma pequena elite, que fez do seu modo de falar o único "correto", "bonito". A norma-padrão foi mais um dos elementos de imposição de uma cultura, de uma língua e de uma religião a povos conquistados e escravizados pelas metrópoles europeias. Desse modo, a norma-padrão é muito mais um discurso sobre a língua, o suporte de uma ideologia linguística autoritária, do que propriamente um guia para os usos adequados e corretos da língua. 
A visão normativa de que a norma linguística é um conjunto de preceitos estabelecidos na seleção do que deve ou não ser usado numa certa língua, considerando fatores linguísticos e não-linguísticos, como tradição e valores socioculturais, como prestígio, elegância, estética, etc., conforme traz o dicionário Houaiss (2002), respalda-se na idéia de que a língua se impõe ao indivíduo. Vista desse modo, a norma linguística estaria imune às intervenções sociais. $O$ uso linguístico, a variação linguística estariam excluídos da língua. A norma-padrão não faz parte da língua, ou seja, não é uma das variedades linguísticas empiricamente observáveis nos uso dos falantes em comunidade. Ela é uma norma no sentido mais jurídico do termo, uma espécie de lei linguística. Porém sabemos que não existe língua, variedade e dialeto sem falantes reais e ninguém fala, todo o tempo, a norma-padrão.

Essa contradição entre a norma-padrão e a fala perpetuou-se ao longo do estruturalismo linguístico e, então, somente em meados dos anos 60, a área da Sociolinguística fez investigações sobre a atuação do indivíduo nessa estrutura, conforme sua inserção no contexto social.

Apresentamos algumas dentre as várias definições de norma linguística, por exemplo, Celso Cunha e Lindley Cintra (1985) dizem que se trata de uma tentativa de descrição do português atual na sua forma culta, isto é, a língua da forma como os escritores portugueses e os brasileiros a utilizavam. Já Rocha Lima (1972) a define como fundamentada nas regras da Gramática Normativa, nas obras dos grandes escritores, em cuja linguagem as classes mais altas põem o seu ideal de perfeição. Segundo Evanildo Bechara (2001), a norma recomenda como devemos falar e escrever segundo os escritores e segundo os gramáticos e dicionaristas esclarecidos. Todos esses gramáticos associam língua culta com escrita literária. Desprezam 
completamente a língua falada. Não distinguem língua escrita de língua falada. De modo que tudo o que não fosse literário, era visto como um "erro" na língua, principalmente na língua falada. Instauraram-se assim várias dicotomias como certo versus errado, bonito versus feio, elegante versus grosseiro, culto versus ignorante.

Assim, norma linguística vai se rotulando atrás de uma língua ideal, baseada no uso linguístico feito pelos grandes escritores, porém a um uso que não corresponde a nenhum conjunto real das regras que governam a atividade linguística por parte dos falantes reais. Desconsidera-se toda e qualquer manifestação falada e escrita da língua por parte de falantes nativos, para considerar esse ideal de língua certa.

Segundo Mattos e Silva (2004), as pessoas que defendem uma norma culta, padronizada, a ser transmitida e controlada pelas instituições sociais, só podem apoiarse em uma gramática ideal, baseada em modelos literários do passado, que se encontra codificada na tradição da gramática pedagógica transmitida no ensino da língua portuguesa. Assim, o português não deve estar voltado a um conjunto de regras e exceções que acabam em si mesmas, como propõe a gramática normativa, nem deve discriminar e desprestigiar os que não a conhecem.

Segundo Bagno (2005), o português não-padrão é inovador porque se deixa levar pelas forças vivas de mudança que estão sempre ativas na língua. Em contrapartida, o português padrão se apega a regras e a explicações para determinados conceitos a fim de jamais alterá-los, tornando-se, dessa forma, conservador.

Ainda, segundo Bagno (2007), a construção de uma norma-padrão, de um modelo idealizado de língua, representa um controle dos processos inerentes de variação e mudança, uma barreira artificial das forças que levam a língua a variar e a mudar. 
O ensino das variantes da Língua Portuguesa é de suma importância e não constitui o "empobreamento" da língua. O falante precisa perceber que sua variante não é a única nem a "errada", ela é apenas mais uma dentre as muitas que ele pode usar.

A norma deveria, então, ser entendida como um alicerce e como base para que os indivíduos se comuniquem, respeitando os limites de cada comunidade, bem como as diversidades que regem o fenômeno linguístico. Podemos ressaltar menos as regras, e nos preocupar mais com a boa comunicação, valorizando a nossa língua e nossa competência enquanto falantes nativos. É preciso reconhecer formas novas da língua e permitir seu convívio tranquilo com as formas consagradas pela tradição normativa.

Segundo Faraco (2008),

estudar, por exemplo, a concordância verbal tem sentido quando claramente articulado com o uso da norma culta (...). Isso pressupõe um trabalho de contraste entre a língua falada espontânea, a língua falada monitorada e a língua escrita (...). Mais ainda: como boa parte dos fatos de concordância envolve estruturas alternativas e não categóricas, seu estudo se justifica também como parte das atividades de reconhecimento da flexibilidade estrutural da língua, que abre amplas faixas de opções expressivas para o falante. Reduzir, contudo, o estudo da concordância a uma lista de regras, cobrando sua aplicação em exercícios insossos e descontextualizados, é atividade inócua (pag. 161).

\subsection{VARIAÇÃO E MUDANÇA}

Para Weinreich, Labov e Herzog (1968), a mudança linguística começa quando uma variante se generaliza num subgrupo de uma comunidade e adquire uma certa direção e significação social. As mudanças acontecem normalmente na estrutura social da comunidade. 
A mudança linguística não constitui um fato isolado, regulado por fatores mecânicos. As mudanças são fatos da estrutura linguística e devem ser explicadas pela lógica do sistema funcional, são, portanto, explicadas segundo sua funcionalidade e segundo a motivação que as realizou. A mudança era vista como sistemática e absoluta. Mas sabemos que toda língua muda com o tempo. E são os falantes, em sociedade, que mudam a língua o tempo todo.

Scherre (1988) considera a variação como advinda da junção de indivíduos com comportamentos linguísticos internamente homogêneos, mas diferenciados entre si. Assumindo assim que a variação existe no comportamento linguístico individual e que ela reflete, no nível grupal, o comportamento linguístico de indivíduos que variam da mesma forma. Além disso, as diferenças entre os agrupamentos de indivíduos são interpretadas como diferenças dialetais ou como indicadores de mudança linguística.

Segundo Weinreich, Labov e Herzog (2006), o estudo da mudança linguística está relacionado a cinco problemas, a saber: o das restrições, o da transição, o do encaixamento, o da avaliação e o da implementação.

Por exemplo, o problema das restrições diz respeito à questão de definir que condições favorecem ou restringem as mudanças linguísticas possíveis. Um possível objetivo para uma teoria da mudança é determinar o conjunto de mudanças e condições possíveis para a mudança. Essa questão conduz a teoria da mudança à idéia de que as mudanças seguem princípios gerais, ou mesmo universais.

Já o problema da transição coloca para a teoria da mudança a necessidade de definir e analisar o percurso através do qual cada mudança se realiza. Isso levanta uma questão fundamental: a mudança se processa por estágios discretos ou através de um continuum? Entre quaisquer dois estágios observados de uma mudança em progresso, 
normalmente se tentaria descobrir o estágio interveniente que define a trilha pela qual uma dada estrutura evolui para outra.

Cabe ressaltar que o sistema linguístico em que a mudança deve ser encaixada não se estabelece no indivíduo, e sim na comunidade de fala. As variáveis intrínsecas a esse sistema definem-se pela covariação com elementos linguísticos e extralinguísticos.

No entanto, sabemos que a mudança linguística não ocorre toda de uma vez dentro da comunidade de falantes, pois uma parte adota mais rapidamente a mudança, enquanto a outra parte conserva por algum tempo as formas antigas. Dessa maneira, o que ocorre é uma competição, uma concorrência entre a variante inovadora e a variante conservadora.

As mudanças linguísticas sob investigação devem ser vistas como encaixadas no sistema linguístico como um todo. O encaixamento se dá tanto na estrutura linguística quanto na estrutura social. Segundo Weinreich, Labov e Herzog (2006), as variantes das variáveis podem ser contínuas ou discretas, em ambos os casos, a variável apresenta um contínuo de valores, pois inclui a frequência de ocorrência de variantes individuais na fala estendida. Vale frisar também que a estrutura linguística está encaixada em um contexto mais amplo da comunidade de fala, de tal modo que variações sociais e geográficas são elementos intrínsecos da estrutura.

O problema da avaliação levanta uma importante discussão acerca do papel do indivíduo frente à mudança e frente à própria língua. O nível de consciência social é uma propriedade importante da mudança linguística que tem de ser determinada. Correlatos subjetivos da mudança são por natureza mais categóricos do que os padrões cambiantes do comportamento. Segundo Weinreich, Labov e Herzog (2006), a 
investigação destes correlatos aprofunda nosso entendimento dos modos como a categorização discreta é imposta ao processo contínuo de mudança.

Com relação ao problema da implementação, o processo global da mudança linguística pode envolver estímulos e restrições tanto da sociedade quanto da estrutura da língua. Se considerarmos o postulado de que a mudança linguística é mudança no comportamento social, sabemos então que as hipóteses preditivas não estarão disponíveis, já que este é um problema comum a todos os estudos do comportamento social. A mudança linguística é gradualmente generalizada a outros elementos do sistema. Novos grupos entram na comunidade de fala, de modo que uma das mudanças secundárias se torna primária. $\mathrm{O}$ alto grau de regularidade de uma certa variante a insere no sistema.

Alguns postulados se fazem presentes acerca do perfil dos indivíduos que terão acesso à norma-padrão, por exemplo, na maioria das mudanças linguísticas, as mulheres estão à frente dos homens. Os membros dos diferentes grupos sociais estigmatizam as formas de menor prestígio e se auto corrigem na fala espontânea na direção da variante mais prestigiosa. Nas etapas iniciais e intermediárias de uma mudança, em progresso, os falantes não parecem ter ainda consciência clara do traço em questão.

Segundo Scherre (1988), a concordância verbal encontra-se num processo de variação, caminhando em duas direções opostas: uma em direção a um sistema sem marcas; outra em direção a um sistema com marcas. A primeira direção envolve, portanto, um mecanismo de perda das marcas de concordância e a segunda envolve um mecanismo de aquisição destas mesmas marcas. Em outras palavras, a primeira direção se relaciona com o princípio da economia morfológica, que resulta em uma 
dependência maior no nível da organização sintática e das relações semânticas. Já a segunda se relaciona com o paralelismo formal. Por exemplo, as regras de concordância são consideradas redundantes, de modo que o excesso de marcas que definem a variante padrão tende a ser eliminado da língua, prevalecendo, pelo princípio da economia, a regra que implementa a variante não-padrão. Ou seja, o princípio da economia morfológica diz respeito ao fato de o falante marcar a pluralidade somente no primeiro elemento do sintagma, o que seria suficiente para indicar a pluralidade da frase, outras marcas seriam vistas como redundantes. Já o paralelismo formal mostra que os falantes são compelidos a usar formas semelhantes por algum princípio mental associativo, que pode estar ligado a uma das formas da mente humana operar, refletido no comportamento humano em geral, ou seja, a presença de marcas de plural no SNsujeito levaria o verbo a sua forma também plural, uma vez que marcas levam a marcas e zeros levam a zeros. 


\section{O FENÔMENO EM ESTUDO}

\subsection{CATEGORIA DE NÚMERO NO PORTUGUÊS}

Nesta seção, tratamos da concordância verbal sob a perspectiva da gramática normativa e da gramática funcional. Após uma breve introdução a respeito do termo "concordância", apresentaremos algumas das regras de concordância verbal encontradas nas gramáticas normativas de Celso Cunha \& Lindley Cintra (2001), Bechara (2000), Rocha Lima (1992), Sacconi (1990) e Said Ali (1969). Em seguida apresentamos a visão da gramática funcional no que tange à concordância verbal, trazendo algumas das considerações de Braga \& Scherre (1976), Lemle \& Naro (1977) e de Bybee (1985).

De acordo com Câmara Júnior (1988), o termo "concordância" é utilizado para designar a relação das categorias gramaticais entre palavras determinantes e palavras determinadas dentro de um sintagma nominal e/ou verbal. Dessa forma, na língua portuguesa, temos a concordância em gênero e número, do adjetivo com seu substantivo e do substantivo ou pronome com o verbo, daí a existência de dois tipos de concordância: a nominal (entre adjetivo e substantivo) e a verbal (entre substantivo e verbo).

Na visão linguística de Mattoso Câmara (1973), a flexão se encontra, em português, no nome, isto é, no substantivo e no adjetivo, para expressar o número e o gênero e, no verbo, para indicar o modo, o tempo, o número e a pessoa.

Existem, em português, mecanismos de pluralização que são estudados e analisados tanto por gramáticos como por linguistas, porém com focos diferentes. Por exemplo, na modalidade falada, temos que considerar a questão fonética do enfraquecimento das finais do português brasileiro, logo o enfraquecimento do $-s$ final, 
no caso de substantivos e/ou adjetivos, e o enfraquecimento do $-m$ final, no caso dos verbos. A desnasalização, como salienta Guy (2000), constitui um fator decisivo para o estabelecimento dos níveis de saliência fônica, uma vez que envolve formas verbais regulares em que a nasalidade é o único traço distintivo entre as formas singular e plural, do tipo ele canta/eles cantam.

Segundo Bagno (2007), o princípio básico da concordância verbal é o da eliminação das marcas redundantes de concordância. A indicação da pluralidade se faz de maneira suficiente por meio de uma única marca morfológica, que aparece no primeiro elemento do grupo a ser pluralizado. Fato que não impede qualquer falante de português compreender que se trata de um plural, o que prova que uma só marca seria perfeitamente suficiente.

Porém vários estudos sociolinguísticos mostraram que há um predomínio das marcas de concordância, prevalecendo o principio do paralelismo formal, onde marcas levam a marcas e zeros levam a zeros (Vieira 1995 e 2008, Gameiro 2005 e 2009, Scherre 1978, 1988, 1992, 1993, 1998; entre outros).

São justamente as marcas e/ou a ausência de marcas de plural presentes na relação entre sujeito e verbo, na modalidade falada e na modalidade escrita, que esse presente trabalho se propõe a investigar.

\subsection{A CONCORDÂNCIA VERBAL SEGUNDO A GRAMÁTICA TRADICIONAL}

Analisamos, neste capítulo, as gramáticas normativas de importantes gramáticos, como Celso Cunha e Lindley Cintra, Bechara, Rocha Lima, Sacconi e Said Ali, no que tange ao fenômeno da concordância verbal. 
Embora tais gramáticos utilizem uma nomenclatura diferente para agrupar os casos de concordância verbal, as regras são as mesmas, fato que atesta que a concordância de número entre sujeito(s) e verbo é considerada como uma regra categórica, já que o verbo concorda em pessoa e em número com seu sujeito.

Para Bechara (2001), concordância verbal é a adaptação do verbo à palavra determinada. Sabemos que há dois tipos de concordância: a nominal e a verbal. A nominal é a que se dá em gênero e número entre o adjetivo e o pronome (adjetivo), o artigo, o numeral ou o particípio (palavras determinantes) e o substantivo ou pronome (palavras determinadas) a que se referem. A verbal é a que se dá em número e pessoa entre substantivo e verbo, pronome pessoal e verbo, pronome indefinido e verbo, pronome demonstrativo e verbo, numeral e verbo a que se referem.

A concordância pode ocorrer de palavra para palavra ou de palavra para o sentido. A concordância de palavra para palavra será total ou parcial (também conhecida como atrativa), conforme se considere a idéia de totalidade ou o mais próximo das palavras determinadas numa série de coordenação.

(01) Honestidade e sabedoria fortalecem todos nós.

(02) Sandra com seu pai foi/foram à praia. (Paladino, 2006, p. 31).

A concordância de palavra para o sentido, também conhecida como concordância "ad sensum" ou silepse, consiste na possibilidade de o sintagma nominal, devido ao seu conteúdo semântico de pluralidade, poder levar o verbo ao plural, mesmo que este esteja mais afastado do substantivo em questão. 
(03) Caíram de joelhos aquele povo nordestino sofrido.

(04) Aquele povo todo participavam da procissão, fervorosos. (Paladino, 2006, p. 32).

De acordo com Gili Gaya (2000), a relação interna que une os elementos componentes de uma dada oração é a concordância existente entre estes componentes, ou seja, a equivalência de gênero e número entre substantivo e adjetivo, além da equivalência de número e pessoa entre um verbo e um sujeito, resultando na concordância nominal e verbal, respectivamente.

Dentre os gramáticos e suas respectivas gramáticas analisadas, Said Ali (1969) é o gramático mais sucinto, dividindo as regras da concordância verbal apenas em duas, a saber: regras gerais e regras especiais. Os demais gramáticos: Celso Cunha e Lindley Cintra (2001), Sacconi (1990), Bechara (2000) e Rocha Lima (1972) separam, de modo geral, em "blocos" as regras da concordância verbal, a saber: com um só sujeito; com mais de um sujeito; casos particulares; concordância do verbo ser.

Said Ali (1969) apresenta as regras divididas em casos gerais e em casos particulares. Inseridos, nos casos gerais, estão os casos de concordância com sujeito simples e com sujeito composto, já que, segundo tal gramático, a regra é clara: o verbo deve concordar com o sujeito, quer ele esteja no singular quer ele esteja no plural, quer ele seja simples, quer ele seja composto. Já, inseridas nos casos particulares, temos expressões como "um e outro", "nem um, nem outro", "um dos que", que não foram construções significativas em nosso corpus, ou seja, não obtivemos um número de ocorrências relevante, sendo assim, não consideraremos tais construções em nosso estudo. 
Os gramáticos, de modo geral, apresentam as regras da concordância, dividindoas em:

A. Com um só sujeito:

(07) O caçador persegue o veado.

(08) Os caçadores perseguem o veado. (Said Ali, 1969, p. 118);

(09) A vida tem uma só entrada: a saída é por cem portas. (Bechara, 2000, p. 554);

(10) A paisagem ficou espiritualizada. (Cunha \& Cintra, 2001, p. 486)

(11) me parece que eles estão casando... (AC 150, L. 423)

(12) alguns cursos que eles gostariam de fazê(r)... (AC 149, L. 312)

B. Com mais de um sujeito:

(13) "... os ódios civis, as ambições, a ousadia dos bandos e a corrupção dos costumes haviam feito incríveis progressos". (Bechara, 2001, p. 554)

(14) Só eu e Florêncio ficamos calados, à margem. (Cunha \& Cintra, 2001, p. 486)

(15) A gasolina e o álcool sobem hoje. (Sacconi, 1990, p. 353)

(16) O desalento e a tristeza abalaram-me. (Rocha Lima, 1972, p. 355) 
(17) A rosa e a camélia são flores lindíssimas. (Said Ali, 1969, p. 119)

(18) esse marido e esses filhos foram ruins pra ela (AC 110, L. 163)

(19) tem o irmão e uma irmã do meu pai que moram lá... mas aí o contato é menor:: (AC 046, L. 302)

Em termos gerais, todos os gramáticos, aqui analisados, apresentam as regras de concordância bastante estruturadas, separadas de acordo com a estrutura frasal, por exemplo, frases com o verbo ser têm uma seção separada das demais; sujeitos compostos também se encontram separados dos sujeitos simples. Parte dos exemplos foram retirados de importantes clássicos da nossa literatura e da literatura portuguesa.

Bechara foi o único linguista, dentre os analisados, a mencionar em sua gramática a linguagem coloquial, classificando-a em concordância de palavra para palavra e de palavra para sentido, onde aparece a intenção do falante/ouvinte, escritor/leitor. Tal linguista escreve também sobre a fala, local propício para o uso do verbo no singular ou no plural a depender do seu sujeito, principalmente, quando este é posposto ou composto.

B.1 Concordância facultativa com o sujeito mais próximo5:

\footnotetext{
${ }^{4}$ Estes exemplos foram retirados do nosso corpus de modalidade falada do banco de dados IBORUNA. ${ }^{5}$ Nesta seção, os gramáticos analisados não apresentam, em seções diferentes, os casos em que temos exemplos com mais de um sujeito e exemplos de sujeito posposto, esses dois casos foram dispostos nessa seção de concordância facultativa com o sujeito mais próximo quer ele esteja posposto ao verbo,
} 
(20) “Que me importava Carlota, o lar, a sociedade e seus códigos?" (Cyro dos Anjos, apud Rocha lima, 1972, p. 355)

(21) O fluxo e o refluxo das ondas nos encanta. (Bechara, 2000, p. 555)

(22) Que te seja propício o astro e a flor... (F. Espanca, apud Cunha \& Cintra, 2001, p. 497)

(23) Passará o céu e a terra, mas minhas palavras ficarão. (Sacconi, 1990, p. 353)

Para Câmara Júnior (1977), a concordância verbal é só o que assinala em português um substantivo como sendo o sujeito da oração, uma vez que a concordância verbal é frequentemente usada como critério para identificação do sujeito da sentença. Entretanto, a própria gramática tradicional considera a possibilidade de, em algumas estruturas, o verbo não concordar com o sujeito, mas com um sintagma que esteja mais próximo ao verbo, como vemos no exemplo abaixo:

(24) Saíram (ou saiu) Pedro e Antônio. (Said Ali, 1969, p. 119)

Vimos com esses exemplos que até mesmo a gramática normativa admite variação da regra, podendo o verbo ficar ora no singular, ora no plural, principalmente, quando temos casos de sujeitos pospostos. Os linguistas afirmam, que a regra da CV, quando o sujeito for composto ou quando ele estiver posposto ao verbo, poderá ser

quer seja um sujeito composto por mais de um núcleo. Por essa razão mantivemos esses exemplos em uma mesma seção. 
feita ou com o constituinte mais próximo ou o verbo poderá ir para o plural, normalmente, para a $3^{\underline{a}}$ pessoa do plural.

Muitas explicações e justificativas são dadas pelos gramáticos, na tentativa de explicar o porquê de tais construções serem aceitas, já que podem variar, ora o verbo pode vir em sua forma singular, ora em sua forma plural.

Não devemos nos esquecer que a Gramática Normativa tem seu foco de interesse restrito, uma vez que todo aparato de conceitos, definições e instrumentos de análise que ela oferece se limita ao estudo da frase, ou seja, o ponto final da oração escrita é o ponto final da análise gramatical. Temos assim a gramática de um discurso planejado, muitas vezes, diferente de um discurso oral espontâneo.

Não gostaríamos de causar a impressão de que estamos criticando a gramática normativa por tentar transmitir uma norma-padrão, sabemos que cada meio tem um fim, e o da gramática normativa é tentar manter um padrão ideal. Entretanto, no caso da concordância verbal, nem mesmo os escritores consagrados a utilizam sistematicamente devido ao grande número de regras facultativas, pois o fato de as regras de concordância verbal estarem entre as que apresentam traços variáveis na língua, até mesmo na visão da Gramática Normativa, nos permite afirmar que a concordância verbal é, de fato, uma regra variável.

\subsection{A CONCORDÂNCIA VERBAL SEGUNDO A GRAMÁTICA FUNCIONAL}

A modalidade falada, em alguns pontos, difere da modalidade escrita. A preocupação com o uso da língua acarreta preocupação com as práticas educacionais. 
Fala e escrita são práticas usadas em contextos diferentes. Estuda-se a língua falada pelo valor cultural que ela tem, pela sua dinamicidade e complexidade, tão igual à língua escrita.

Dik (1978) aponta que, num paradigma funcional, a língua é concebida, em primeiro lugar, como um instrumento de interação social entre seres humanos, usada com o objetivo principal de estabelecer relações comunicativas entre os usuários. Uma abordagem funcionalista de uma língua natural sempre tem como objetivo o interesse de verificar como os usuários dessa língua se comunicam de maneira eficiente.

Neves (2004) entende que a língua, bem como a gramática, não pode ser descrita como um sistema autônomo, já que a gramática não pode ser entendida sem parâmetros, como, por exemplo, cognição e comunicação, processamento mental, interação social e cultural, mudança e variação, aquisição e evolução.

A partir do contexto situacional, o falante seleciona o registro a ser utilizado em sua atuação linguística. Suas escolhas dependem da intenção do falante, da forma que ele considera adequada para emitir sua informação pragmática e de como ele deseja que o destinatário a receba e retorne a ele.

No que concerne à concordância verbal, podemos dizer que esse fenômeno tem sido amplamente estudado no Brasil sob o suporte teórico-metodológico da Teoria da Variação. Os estudos, em torno da concordância, iniciaram-se, no Brasil, com os trabalhos pioneiros sobre a concordância verbo/sujeito com Lemle e Naro em 1977. Esses estudos se desenvolveram de tal forma que diversos trabalhos e grupos de pesquisas multiplicaram-se no país, expandindo a pesquisa na área da Sociolinguística Quantitativa. Entre os diversos trabalhos desenvolvidos, destacamos o de Braga \& 
Scherre (1976) por se tratar de um estudo pioneiro acerca da concordância ${ }^{6}$ no português falado no Brasil. Além desse trabalho, diversos trabalhos em pontos geográficos distintos do país descrevem o padrão de uso da concordância tanto nominal quanto verbal. Esses estudos têm evidenciado que o fenômeno da variação entre os elementos pluralizáveis do $\mathrm{SN}$ e o verbo não se restringe a determinadas regiões do país; sendo, portanto, decorrente de contextos linguísticos e sociais semelhantes, isto é, há uma sistematicidade do fenômeno, fato que nos possibilita presumir em quais estruturas a aplicação da regra variável de concordância verbal será mais provável, o que, para Scherre \& Naro (1997), configura-se como um caso de variação linguística inerente.

Como dito acima, os estudos sociolinguísticos acerca da concordância verbal tiveram início, no Brasil, com os trabalhos pioneiros de Naro e Lemle. Em 1977, foi feita uma pesquisa, seguindo a metodologia laboviana, com 20 informantes integrantes do Movimento Brasileiro de Alfabetização (MOBRAL), que fazem parte do Projeto de pesquisa Competências Básicas do Português.

Segundo os linguistas, a alternância da regra da concordância por um mesmo informante, às vezes na mesma sentença e até com o mesmo verbo, permitiu-lhes tratar a concordância verbal como regra variável.

O corpus do trabalho compreendeu sete entrevistas de uma hora de gravação com cada um dos 20 informantes. Os fatores controlados foram: variável estilística, variável morfológica, variável sintática e variável semântica. A variável estilística consiste nos diferentes estilos de formalidade. A variável morfológica se relaciona à

\footnotetext{
${ }^{6}$ Embora seja um trabalho referente à concordância nominal, foi um dos trabalhos pioneiros acerca da concordância, por esse motivo o mencionamos em nossa pesquisa.
} 
saliência fônica. A variável sintática consiste na posição que o sujeito ocupa perante o verbo e a variável semântica caracteriza o sujeito como sendo determinado ou indeterminado.

Lemle e Naro (1977) estabelecem uma generalização sobre as variáveis linguísticas apresentadas: para eles, a concordância verbal tende a acontecer na medida em que a oposição entre as formas verbais singular/plural for mais perceptível para o falante. Eles defendem a idéia de que há alguns fatores condicionadores para a aplicação da regra de concordância verbal.

Toda língua impõe para o falante certas escolhas, o que acarreta alguns problemas devido à situação sociocultural e à situação da fala. Diferenças linguísticas, entre diferentes classes sociais, resultam em diferentes modos de fala. Porém, cabe frisar, que não há modo de fala melhor ou pior, há diferenças linguísticas, que são riquíssimas para nós, sociolinguistas.

Outra importante contribuição foi a da linguista Bybee (1985) que atribuiu diferentes graus de relevância para as categorias que afetam uma base de conteúdo significativo. Por exemplo, na modificação de uma base verbal, a categoria aspecto é muito mais relevante do que a categoria responsável pela concordância númeropessoal, já que a primeira descreve a temporalidade interna do estado-de-coisas codificado pelo próprio verbo, enquanto a segunda apenas se refere ao(s) argumento(s) verbal(is). Em outras palavras, categorias de concordância não se referem às situações descritas pelo verbo em si, mas sim, aos participantes envolvidos na situação. Iconicamente categorias que ocupam a posição mais à esquerda contribuem mais significativamente para a modificação do conteúdo da base verbal do que as categorias posicionadas mais à direita. É de interesse apontar que, nessa escala, categorias de 
concordância (número e pessoa) são as de menor relevância para o significado codificado na base verbal. Pois quanto mais próximo ao radical, mais relevante é o morfema. Exemplificando, o morfema modo-temporal é mais relevante que o morfema número-pessoal, isso porque o morfema modo-temporal diz respeito diretamente ao verbo, enquanto o morfema número-pessoal diz respeito ao sujeito, sendo exterior ao verbo, daí ele ser menos relevante.

Ao lado desse princípio de relevância para os morfemas modificadores de base verbal, a redundância no emprego das regras de concordância em contextos oracionais é outro ponto destacado por Bybee. Em algumas línguas, a concordância verbal é exigida, ainda que o número seja expresso pelo SN-sujeito, como é o caso da língua portuguesa. A redundância seria um dos fatores determinantes da não-marcação de plural nas formas verbais, de um modo geral.

No francês, por exemplo, ainda que na escrita os verbos recebam a marca de concordância de $3^{\text {a }}$ pessoa do plural, oralmente, na linguagem padrão, não há distinção entre a forma singular e a forma plural, já que a pronúncia das duas formas é exatamente a mesma para grande parte dos verbos. Esse apagamento da marcação de plural se estende também à concordância nominal de número, em que, na linguagem oral, o morfema "-s" característico do plural é apagado em inúmeros contextos. Esse aspecto típico da oralidade mostra seus efeitos na estrutura frasal da língua francesa, hoje caracterizada pelo preenchimento da posição do sujeito, assim como a língua inglesa. 


\subsection{CONCORDÂNCIA VERBAL: DA FALA PARA A ESCRITA ${ }^{7}$}

Não se pode observar satisfatoriamente as semelhanças e diferenças entre fala e escrita sem considerar a distribuição de seus usos na vida cotidiana.

Como salienta Marcuschi (2003), a escrita não pode ser vista como uma representação da fala. Isso porque a escrita não consegue reproduzir muitos dos fenômenos da oralidade, como, por exemplo, a prosódia, a gestualidade, os movimentos do corpo de um modo geral ou até mesmo o ritmo.

Oralidade e escrita são práticas e usos da língua com características próprias, mas não suficientemente opostas para caracterizar dois sistemas linguísticos nem uma dicotomia. As limitações e os alcances de cada uma estão dados pelo potencial do meio básico de sua realização: som de um lado e grafia de outro, embora elas não se limitem a som e grafia. Todos os povos têm ou tiveram uma tradição oral, mas relativamente poucos tiveram ou têm uma tradição escrita, isso, é claro, não torna a oralidade mais importante ou prestigiosa que a escrita. Trata-se, portanto, de perceber que a oralidade tem uma "primazia cronológica" indiscutível sobre a escrita. No entanto, os usos da escrita quando arraigados numa dada sociedade, impõem- se com uma violência inusitada e adquirem um valor social até superior à oralidade.

A fala, enquanto manifestação da prática oral, é adquirida naturalmente em contextos informais do dia-a-dia e nas relações sociais e dialógicas que se instauram desde o momento em que a mãe tem o seu bebê. A língua falada apresenta frequentemente variantes regionais que, embora apareçam também na língua escrita, nesta são menores e menos claras.

\footnotetext{
${ }^{7}$ Queremos deixar claro que nosso intuito, nesse trabalho, não é de comparar a modalidade falada com a escrita, mas sim de analisar o funcionamento da concordância verbal em ambas as modalidades.
} 
Segundo Borba (1970), sendo aquisição oral, a língua falada é propriedade coletiva enquanto a escrita, de aquisição mais ou menos longa, pressupõe contato com a escola e tem caráter individual.

O aprendizado e o uso de uma língua natural é uma forma de inserção cultural e de socialização. Por outro lado, a escrita enquanto manifestação formal do letramento, em sua faceta institucional, é adquirida em contextos formais como a escola.

A escrita seria um modo de produção textual-discursiva para fins comunicativos com certas especificidades materiais e se caracterizaria por sua constituição gráfica, embora envolva também recursos de ordem pictórica. Trata-se de uma modalidade de uso da língua complementar à fala. Segundo Borba (1970), a língua escrita é conservadora por causa da tradição escolar e literária, que põem obstáculos às modificações da escrita.

A modalidade falada e a modalidade escrita apresentam algumas características diferentes, a saber: a fala é contextualizada, dependente, implícita, redundante, nãoplanejada, imprecisa, não-normatizada e fragmentária. Já a escrita se caracteriza por ser descontextualizada, autônoma, explícita, condensada, planejada, precisa, normatizada e completa.

As línguas não são homogêneas nem uniformes sob o ponto de vista de seu uso. As relações fala e escrita dizem respeito a questões de uso da língua. É importante ressaltar que a variação se dá tanto na modalidade falada como na escrita, o que evita o equívoco de identificar uma modalidade como sendo superior à outra.

As diferenças entre fala e escrita se dão dentro de um continuum tipológico das práticas sociais de produção textual e não na relação dicotômica de dois polos opostos. 
De acordo com Marcuschi (2003), o continuum dos gêneros textuais distingue e correlaciona os textos de cada modalidade, falada e escrita, quanto às estratégicas de formulação que determinam o continuum das características que produzem as variações das estruturas textuais-discursivas, seleções lexicais, estilo, grau de formalidade, que se dão num continuum de variações, surgindo daí semelhanças e diferenças ao longo de continuuns sobrepostos. Isso equivale a dizer que tanto a fala como a escrita apresentam um continuum de variações, ou seja, a fala varia e a escrita varia.

Para constatar como a concordância verbal tem se mostrado tanto na modalidade falada quanto na escrita, analisaremos, além da fala de 24 informantes, mais de 600 redações escolares, feitas por alunos do $1^{\circ}$ ano do Ensino Fundamental I ao $3^{\circ}$ ano do Ensino Médio. Queremos, com isso, analisar como se dá a realização da regra variável de concordância verbal em ambas as modalidades. 


\section{PROCEDIMENTOS METODOLÓGICOS}

O caráter social dos fatos linguísticos e a percepção da variabilidade à qual a língua está submetida são pontos essenciais no que tange à reflexão sobre a natureza da linguagem humana. Deste modo, língua, sociedade e sujeito são realidades que se relacionam, a existência de uma está diretamente relacionada com a existência dos outros.

Reconhecer e estudar a variação linguística como um fenômeno presente em todas as línguas naturais, incluindo o português brasileiro, é um dos primeiros passos para contribuirmos com a descrição do português falado. Pensando em colaborar na caracterização do português falado no interior paulista e na caracterização da escrita escolar dessa mesma região, o presente trabalho tem como objetivo principal estudar em quais contextos a marca formal de plural do verbo apresenta uma tendência maior de ocorrer. Em outras palavras, queremos constatar quais variáveis linguísticas e extralinguísticas favorecem a presença ou a ausência da marca de plural no verbo.

Devemos ressaltar que os dados de fala analisados, neste trabalho, pertencem ao Departamento de Estudos Linguísticos e Literários do IBILCE/UNESP, sob a denominação "O português falado no interior paulista: constituição de um banco de dados anotado para o seu estudo" (Processo FAPESP 03/08058-6).

Utilizando 24 amostras de fala desse banco de dados, usaremos, como ferramenta principal, a Teoria da Variação Linguística (LABOV, 1972), investigaremos, por meio do controle de variáveis sociais e linguísticas, a concordância verbal. Para tanto, serão controladas as variáveis ${ }^{8}$ extralinguísticas gênero (masculino/feminino),

\footnotetext{
${ }^{8}$ Dá-se o nome de variável linguística ao conjunto constituído por formas linguísticas diferentes que realizam um mesmo significado referencial. Já variantes linguísticas são cada uma das maneiras de se dizer a mesma coisa em um
} 
faixa etária (7-15, 16-25, 26-35, 36 a 55 e mais de 55 anos), escolaridade (Ensino Fundamental I e II, Médio e Superior), renda sócio-econômica (de 6 a 10 salários mínimos e de 11 a 24 salários mínimos) e tipo de relato, já que cada informante contribuiu com cinco tipos de relato: narrativa de experiência pessoal, narrativa recontada, relato descritivo, relato de procedimento e relato de opinião. Como variáveis linguísticas consideramos: paralelismo formal (presença de marca formal de plural no primeiro e único elemento do SN; presença de marca formal de plural em dois ou mais elementos que compõem o SN; ausência de marca formal de plural no elemento que antecede o verbo); traço semântico do sujeito ([-humano, +animado], [+humano], [-animado]); saliência fônica (come/comem; está/estão; falou/falaram; trouxe/trouxeram; é/são; faz/fazem) estrutura do sujeito (nome substantivo no singular com um ou mais determinantes no plural; nome substantivo no plural; pronomes pessoais; numeral e pronome demonstrativo); distância e posição do sujeito (imediatamente posterior, imediatamente anterior; material interveniente com até quatro sílabas e mais de quatro sílabas) e valor semântico do verbo (ação, processo, açãoprocesso e estado). Almejamos constatar quais desses fatores propiciam a presença da marca formal de plural e quais a desfavorecem.

Analisamos redações escolares, para a composição do corpus de modalidade escrita, de alunos do Ensino Fundamental I, do Ensino Fundamental II e do Ensino Médio. Controlamos as seguintes variáveis linguísticas para nosso corpus da modalidade escrita: paralelismo formal (presença de plural na palavra que compõe o SN e ausência de plural na palavra que compõe o SN); saliência gráfica/fônica 
(come/comem; está/estão; falou/falaram; trouxe/trouxeram; é/são; faz/fazem); posição do sujeito (anteposto e posposto); classe gramatical do núcleo do sujeito (pronome pessoal do caso reto, pronome indefinido, numeral e substantivo) e presença versus ausência de pronome pessoal (eles ou elas). Como variável extralinguística, controlamos somente a escolaridade (ensino fundamental I, ensino fundamental II e ensino médio). Tanto na modalidade escrita como na modalidade falada, optamos por trabalhar com as variáveis que se revelaram significativas em outros estudos, a fim de verificarmos se tal relevância também acontecia em nossa região, em nosso corpus, por essa razão nem todas as variáveis abordadas na modalidade escrita são iguais as abordadas na modalidade falada.

A grande quantidade de trabalhos que envolvem a concordância verbal reflete sua importância para os estudos linguísticos e sua fecundidade de campos de análise. Compreender a variação e observar seus reais contextos de uso poderia ser útil até mesmo em explicações em sala de aula, que talvez fossem mais eficazes do que apenas listar os casos de exceções. O que observamos, nas gramáticas escolares, é uma distância cada vez maior entre o que elas prescrevem e o que efetivamente é utilizado pelos falantes.

\subsection{SOBRE A CIDADE DE SÃO JOSÉ DO RIO PRETO}

São José do Rio Preto é um município brasileiro do Estado de São Paulo. É a maior cidade do noroeste do estado, sua economia está baseada no comércio, prestação de serviços, indústrias diversas e agricultura. 
Foi fundada em 19 de Março de 1852, sua história inicia-se com o desbravamento e a ocupação do solo do sertão paulista em meados do século XIX. A partir de 1840, os mineiros, primeiros moradores de Rio Preto, fixaram-se e deram início à exploração agrícola e à criação de animais domésticos.

Em 1852, Luiz Antônio da Silveira doou parte de suas terras ao seu santo protetor, São José. Em 19 de março de 1852, João Bernardino de Seixas Ribeiro (fundador de São José do Rio Preto) já tinha construído uma casa de sapé nas terras do patrimônio.

Rio Preto era servido por trilhas por onde circulavam, com grandes dificuldades, carroças, carros de bois, tropas, que, com o passar do tempo, se transformaram em estradas de rodagem e caminhos de ferro.

A primeira fonte escrita sobre São José do Rio Preto data de1867, quando o Visconde de Taunay, ao retornar da Guerra do Paraguai, pernoitou no vilarejo e registrou em seu diário o estado precário em que o vilarejo se encontrava.

O município de São José do Rio Preto durante 27 anos pertenceu ao município de Jaboticabal, no período que vai de 1867 até 1894. Era até então um distrito. Bernardino de Campos, governador do Estado de São Paulo, na época, assinou a Lei no 294, no dia de 19 de julho de 1894, criando o Município de São José do Rio Preto, tendo como divisas os rios Tietê, Paraná, Grande e Turvo. O nome da rua principal era Bernardino de Campos em homenagem ao então presidente (governador) do Estado de São Paulo que criou o município.

A origem do nome do município veio, da junção do nome do padroeiro da cidade, São José, e do rio que corta o município, Rio Preto. 
A partir de 1906, a cidade tem seu nome reduzido para Rio Preto. Somente em 1945 retoma o nome original de São José do Rio Preto.

Com a chegada da Estrada de Ferro Araraquarense (EFA), em 1912, a cidade assume o seu destino de polo comercial de concentração de mercadorias produzidas no então conhecido "Sertão de Avanhandava" e de irradiação de materiais vindos da capital.

Destacaram-se três pessoas na criação do município: Pedro do Amaral Campos, próspero comerciante atacadista; João Bernardino de Seixas Ribeiro, capitão que construiu o primeiro casebre de pau-a-pique e Adolfo Guimarães Correia, vereador por muitos anos em São José do Rio Preto.

Em 1955, a Câmara Municipal de Rio Preto aprovou a criação de sua Universidade municipal. Dois anos depois, a Faculdade de Filosofia, Ciências e Letras começou a funcionar, e no ano seguinte foi estadualizada. Atualmente, a cidade tem faculdades mantidas pelo Estado: IBILCE/UNESP - Instituto de Biociências, Letras e Ciências Exatas da Universidade Estadual Paulista "Júlio de Mesquita Filho" - e a FAMERP - Faculdade de Medicina de Rio Preto. Rio Preto conta ainda com sete faculdades privadas.

A estimativa da população de São José do Rio Preto, no último censo, em 2007, foi de 402.770 habitantes. Atualmente, Rio Preto apresenta uma área territorial de 431 $\mathrm{km}^{2}$.

A cidade de São José do Rio Preto tem 141 escolas do ensino fundamental, distribuídas da seguinte maneira: 31 escolas públicas estaduais, 66 escolas públicas municipais e 44 escolas privadas. São 53 escolas de ensino médio, sendo 28 escolas públicas estaduais e 25 escolas privadas. 
Em 2008, tivemos um total de 49.739 de matrículas do ensino fundamental, sendo 17.531 em escolas públicas estaduais, 20.256 em escolas públicas municipais e 11.952 em escolas privadas. No ensino médio, foram feitas 16.267 matrículas, sendo 12.378 em escolas públicas estaduais e 3.889 em escolas privadas. Matricularam-se, no ensino superior, 23.369 alunos, sendo 2.673 em universidades públicas estaduais e 20.696 em universidades privadas. São José do Rio Preto transformou-se em um grande e importante centro de estudos.

A incidência de pobreza da região não atinge a margem de $10 \%$. Fato que atesta o grande desenvolvimento sócio-econômico da cidade.

\subsection{SOBRE A CONSTITUIÇÃO DO CORPUS DA MODALIDADE FALADA}

Já foi bastante explicitado que o objeto de estudo da sociolinguística é a língua falada, observada, descrita e analisada em seu contexto social, isto é, em situações reais de uso. Para tanto, cabe ao sociolinguista montar seu corpus de estudo, o que implica em algum tipo de registro; o observador, pesquisador, deve interferir pouco; o falante tem que estar consciente de que será gravado e que será objeto de análise e o anonimato dele deve ser mantido.

A presença do observador, o pesquisador, permite que ele tenha acesso a fatos linguísticos e discursivos que não poderia ter se não estivesse ali, porém sua presença pode gerar um desconforto para o informante, que, por sua vez, pode monitorar sua fala, não sendo espontâneo. Para evitar tal monitoramento, o documentador deve fazer perguntas que envolvam o informante, para que ele se esqueça da presença do gravador. 
O Projeto mais conhecido de estudo da língua falada no Brasil é o NURC, criado em 1970 e desenvolvido por um grupo de lingüistas e pesquisadores nas cidades de São Paulo, Recife, Salvador, Porto Alegre e Rio de Janeiro. O objetivo deste projeto constitui em documentar e descrever a norma objetiva do português culto falado do Brasil. Podemos destacar também o crescente número de Atlas que vêm sendo desenvolvidos em diferentes regiões do Brasil com o intuito de coletar dados de fala de diversas regiões. Há ainda, outros projetos coletivos como o Peul/RJ, o Varsul, o Projeto Gramática do Português Falado e o IBORUNA, banco de dados do qual procedem as amostras de fala que nos servirão de corpus, sendo assim, cabe-nos mencionar alguns procedimentos metodológicos seguidos na sua composição (cf. GONÇALVES, 2005).

A criação do banco de dados IBORUNA foi uma iniciativa inédita, uma vez que é o primeiro banco de dados composto com amostras de fala do Noroeste do Estado de São Paulo, o qual envolve as cidades de São José do Rio Preto, Bady Bassit, Mirassol, Guapiaçu, Onda Verde, Cedral e Ipiguá.

Os informantes foram definidos pelo cruzamento de quatro variáveis sociais, a saber: sexo/gênero (masculino e feminino); faixa etária (de 7 a 15 anos, de 16 a 25 anos, de 26 a 35 anos, de 36 a 55 anos e mais de 55 anos); nível de escolaridade (1ํㅜ ciclo do Ensino Fundamental, $2^{\circ}$ ciclo do Ensino Fundamental, Ensino Médio e Ensino Superior) e renda familiar (até 5 salários mínimos, de 6 a 10 salários mínimos, de 11 a 24 salários mínimos e mais de 25 salários mínimos). Tais informantes contribuíram com cinco tipos de textos orais diferentes, a saber: narrativa de experiência pessoal, narrativa recontada, relato de descrição, relato de procedimento e relato de opinião. A razão para obtenção desses tipos textuais deve-se, em grande parte, à dificuldade de 
delimitações de sequências tipológicas em textos orais, quando se deseja correlacionar determinadas manifestações linguísticas a gêneros textuais. Seria ingenuidade, entretanto, esperar a obtenção de textos genuinamente narrativos, opinativos, injuntivos e descritivos. Assim, por meio de roteiro de entrevista previamente definido, podíamos esperar sempre a predominância dos tipos textuais almejados.

Além de residir nas cidades abrangidas pelo projeto, era necessário que o informante nela residisse, desde pelo menos os seus cinco anos de idade, ou, ainda, que houvesse nascido na cidade.

Do cruzamento das quatro variáveis sociais constituíram-se os perfis da Amostra Censo (AC) com 160 células, que definiram os informantes contatados. Dessas 160 células, oito foram excluídas pela impossibilidade de serem preenchidas (por exemplo, faixa etária de 7 a 15 anos com escolaridade Ensino Superior), obtivemos, então, um total de 152 informantes (gravações com duração aproximada de 40 minutos), de acordo com a distribuição apresentada no quadro a seguir. 


\begin{tabular}{|c|c|c|c|c|c|c|c|c|c|c|c|}
\hline \multirow{2}{*}{\multicolumn{2}{|c|}{$\begin{array}{l}\text { RENDA/GÉNERO } \\
\text { FAIXA ETÁRIA/ } \\
\text { ESCOLARIDADE }\end{array}$}} & \multicolumn{2}{|c|}{ + DE $25 \mathrm{SM}$} & \multicolumn{2}{|c|}{ DE 11 A 24 SM } & \multicolumn{2}{|c|}{ DE 6 A 10 SM } & \multicolumn{2}{|c|}{ ATE 5 SM } & \multirow{2}{*}{$\begin{array}{l}\text { SUB } \\
\text { TOTAL } \\
\text { DE INF. }\end{array}$} & \multirow{2}{*}{$\begin{array}{l}\text { TOTAL } \\
\text { DE } \\
\text { INF. }\end{array}$} \\
\hline & & \multirow{2}{*}{$\frac{\text { MASC }}{001}$} & FEM & \multirow{2}{*}{$\frac{\text { MASC }}{003}$} & FEM & \multirow{2}{*}{$\frac{\text { MASC }}{005}$} & FEM & \multirow{2}{*}{$\frac{\text { MASC }}{007}$} & \multirow{2}{*}{ FEM } & & \\
\hline \multirow{3}{*}{$\begin{array}{l}7 \text { A } 15 \\
\text { ANOS }\end{array}$} & $11^{\circ} \mathrm{CEF}$ & & 002 & & 004 & & 006 & & & 8 & \multirow{3}{*}{24} \\
\hline & $2^{\circ} \mathrm{C} \mathrm{EF}$ & 009 & 010 & 011 & 012 & 013 & 014 & 015 & 016 & 8 & \\
\hline & ENSINO M & 017 & 018 & 019 & 020 & 021 & 022 & 023 & 024 & 8 & \\
\hline \multirow{4}{*}{$\begin{array}{l}16 \text { A } \\
25 \\
\text { ANOS }\end{array}$} & $1^{\circ} \mathrm{C} \mathrm{EF}$ & 025 & 026 & 027 & 028 & 029 & 030 & 031 & 032 & 8 & \multirow{4}{*}{32} \\
\hline & $2^{\circ} \mathrm{CEF}$ & 033 & 034 & 035 & 036 & 037 & 038 & 039 & 040 & 8 & \\
\hline & ENSINO M & 041 & 042 & 043 & 044 & 045 & 046 & 047 & 048 & 8 & \\
\hline & SUPERIOR & 049 & 050 & 051 & 052 & 053 & 054 & 055 & 056 & 8 & \\
\hline \multirow{4}{*}{$\begin{array}{l}26 \text { A } \\
35 \\
\text { ANOS }\end{array}$} & $1^{\circ} \mathrm{CEF}$ & 057 & 058 & 059 & 060 & 061 & 062 & 063 & 064 & 8 & \multirow{4}{*}{32} \\
\hline & $2^{\circ} \mathrm{C} \mathrm{EF}$ & 065 & 066 & 067 & 068 & 069 & 070 & 071 & 072 & 8 & \\
\hline & ENSINO M & 073 & 074 & 075 & 076 & 077 & 078 & 079 & 080 & 8 & \\
\hline & SUPERIOR & 081 & 082 & 083 & 084 & 085 & 086 & 087 & 088 & 8 & \\
\hline \multirow{4}{*}{$\begin{array}{l}36 \text { A } \\
55 \\
\text { ANOS }\end{array}$} & $1^{\circ} \mathrm{C} \mathrm{EF}$ & 089 & 090 & 091 & 092 & 093 & 094 & 095 & 096 & 8 & \multirow{4}{*}{32} \\
\hline & $2^{\circ} \mathrm{CEF}$ & 097 & 098 & 099 & 100 & 101 & 102 & 103 & 104 & 8 & \\
\hline & ENSINO M & 105 & 106 & 107 & 108 & 109 & 110 & 111 & 112 & 8 & \\
\hline & SUPERIOR & 113 & 114 & 115 & 116 & 117 & 118 & 119 & 120 & 8 & \\
\hline \multirow{4}{*}{$\begin{array}{l}+ \text { DE } \\
55 \\
\text { ANOS }\end{array}$} & $1^{\circ} \mathrm{C} \mathrm{EF}$ & 121 & 122 & 123 & 124 & 125 & 126 & 127 & 128 & 8 & \multirow{4}{*}{32} \\
\hline & 20 C EF & 129 & 130 & 131 & 132 & 133 & 134 & 135 & 136 & 8 & \\
\hline & ENSINO M & 137 & 138 & 139 & 140 & 141 & 142 & 143 & 144 & 8 & \\
\hline & SUPERIOR & 145 & 146 & 147 & 148 & 149 & 150 & 151 & 152 & 8 & \\
\hline \multirow{4}{*}{$\begin{array}{l}\text { SUBTO } \\
\text { TAL DE } \\
\text { INF. }\end{array}$} & $1^{\circ} \mathrm{CEF}$ & 5 & 5 & 5 & 5 & 5 & 5 & 5 & 5 & 40 & \multirow{7}{*}{152} \\
\hline & $2^{\circ} \mathrm{CEF}$ & 5 & 5 & 5 & 5 & 5 & 5 & 5 & 5 & 40 & \\
\hline & ENSINO M & 5 & 5 & 5 & 5 & 5 & 5 & 5 & 5 & 40 & \\
\hline & SUPERIOR & 4 & 4 & 4 & 4 & 4 & 4 & 4 & 4 & 32 & \\
\hline \multirow{3}{*}{\multicolumn{2}{|c|}{$\begin{array}{l}\text { TOTAL DE } \\
\text { INFORMANTES }\end{array}$}} & 19 & 19 & 19 & 19 & 19 & 19 & 19 & 19 & & \\
\hline & & 3 & & \multicolumn{2}{|c|}{38} & 3 & & 3 & & & \\
\hline & & & & & & & & & & & \\
\hline
\end{tabular}

O número em cada célula indica o perfil social de cada informante.

Quadro 1: Distribuição e identificação dos informantes da Amostra Censo por variáveis sociais

Se a variável origem geográfica do informante tivesse sido incluída e se atendida a recomendação de $5^{9}$ informantes por célula, a amostragem final seria de 5320 informantes, o que dificultaria a exequibilidade do projeto. Sendo assim, a definição da AC pautou-se pelos seguintes critérios: (a) preenchimento de apenas um informante por

\footnotetext{
${ }^{9}$ Segundo Tarallo (2003), a quantidade mínima de cinco informantes por célula garante a representatividade da amostra. De acordo com o linguista, a medida de cinco informantes para cada combinação dos fatores extralinguísticos pode ser útil no momento de definir e caracterizar o universo da amostra.
} 
célula; (b) distribuição proporcional dos 152 informantes ao número de habitantes das áreas geográficas consideradas, conforme mostra o gráfico abaixo:

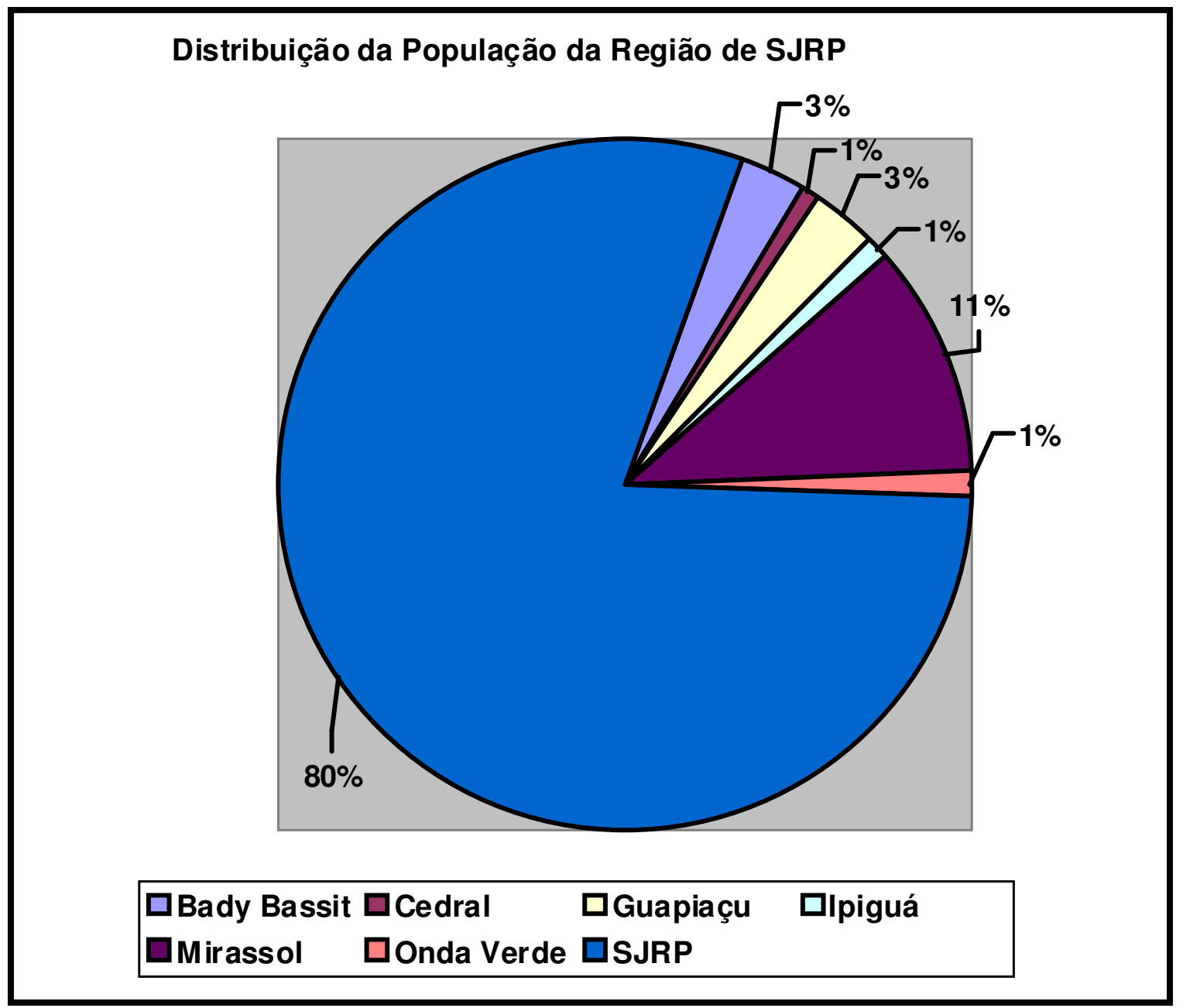

Gráfico 1: Distribuição da população da região de SJRP

Como já mencionado, as cidades selecionadas possuem número de habitantes diferentes umas das outras, o que faz com que a quantidade de informantes requerida seja proporcional a esse número; assim, no gráfico acima, temos a distribuição da população da Região de São José do Rio Preto em percentuais. Já no gráfico abaixo, temos o número de informantes da amostra censo por cidade. 


\section{Número de informantes da Amostra Censo por cidade}

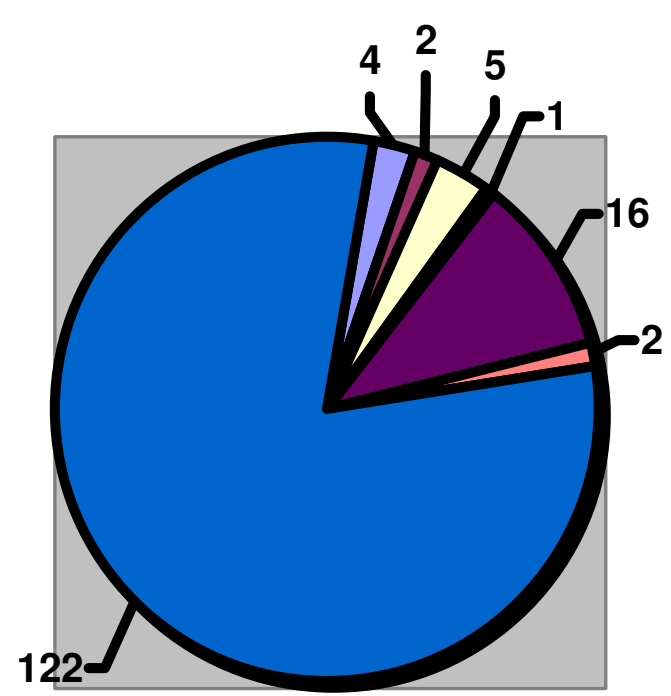

\begin{tabular}{|l|}
\hline Bady Bassit \\
$\square$ Cedral \\
$\square$ Guapiaçu \\
$\square$ Ipiguá \\
$\square$ Mirassol \\
$\square$ Onda Verde \\
GJRP \\
\hline
\end{tabular}

Gráfico 2: Número de informantes da AC por cidade

A manutenção do número de 152 informantes não compromete a representatividade da amostra, pois como já demonstrava Labov (1972), ao considerar que a variação é bastante padronizada e, mesmo não havendo um imenso número de falantes para sua comprovação, a regularidade linguística emerge, o que autoriza generalizações acerca da língua usada na comunidade como um todo. Como adverte Paiva (1999), o fato de termos somente um informante para cada célula não pode ser ignorado, embora saibamos que tal fato não compromete o estudo sociolinguístico, desde que se atente para duas questões relevantes: a necessidade de usar técnicas estatisticamente válidas de amostragem e o conhecimento prévio das dimensões importantes da estratificação, de forma a poder planejar corretamente a amostragem.

O projeto ALIP foi uma iniciativa concebida no interior do Grupo de Pesquisa em Gramática Funcional, (GPGE) da UNESP de São José do Rio Preto, entre os anos de 
2002 e 2003, em razão do interesse dos membros do grupo "Descrição Funcional do Português Oral e Escrito" e "Variação e Mudança Linguística", como linhas de pesquisa que têm como principal diretriz o enfoque da língua usada no seu contexto social.

No que se refere aos aspectos éticos da pesquisa, todos os informantes cederam de livre e espontânea vontade suas amostras de fala, expressando, por meio do termo de declaração, sua adesão livre e consentida ao projeto, cujos objetivos Ihes foram claramente explicitados.

O banco de dados Iboruna é hoje uma realidade, comportando amostras de fala que servem a propósitos investigativos diversificados da pesquisa linguística realizada no interior do Estado de São Paulo.

\subsection{COMPOSIÇÃO DA SUBAMOSTRA DA MODALIDADE FALADA}

Os estudos, no Brasil, acerca da concordância verbal, sobre a ótica da sociolinguística, foram iniciados por Braga \& Scherre em 1976, que analisaram a fala de informantes residentes no Rio de Janeiro. Em 1977, Braga deu prosseguimento à pesquisa sobre o mesmo fenômeno linguístico, considerado como regra variável no português falado no Brasil.

Scherre, em 1976, utilizou como amostra de fala 10 informantes. Pontes, em 1979, utilizou 20 informantes. Carvalho Nina, em 1980, também analisou a fala de 20 informantes. Coelho de Carvalho, em 1997, utilizou 30 informantes. Como observamos a amostra de fala desses linguistas varia de 10 a 30 informantes. Sendo assim, devido à recorrência de tal quantidade de informantes optamos por trabalhar com 24 informantes do banco de dados IBORUNA, para analisar a manifestação do fenômeno da concordância verbal na fala de tais informantes. Os informantes foram selecionados 
mediante a análise de seus respectivos perfis sociais, a fim de que fosse selecionado o maior número de perfis sociais possível, garantindo a homogeneidade da amostra. Dessa forma, foram selecionados 12 homens e 12 mulheres, ambos riopretenses, estratificados socialmente como mostra o quadro abaixo:

\begin{tabular}{|c|c|c|c|c|}
\hline $\mathbf{N}^{\circ}$ do Informante & Sexo/Gênero & Escolaridade & Faixa Etária & Renda Familiar \\
\hline 012 & Feminino & Ensino Fund. & 7 a 15 anos & 11 a 24 SM \\
\hline 013 & Masculino & Ensino Fund. & 7 a 15 anos & 6 a 10 SM \\
\hline 020 & Feminino & Ensino Médio & 7 a 15 anos & 11 a 24 SM \\
\hline 021 & Masculino & Ensino Médio & 7 a 15 anos & 6 a 10 SM \\
\hline 043 & Masculino & Ensino Médio & 16 a 25 anos & 11 a 24 SM \\
\hline 044 & Feminino & Ensino Médio & 16 a 25 anos & 11 a 24 SM \\
\hline 045 & Masculino & Ensino Médio & 16 a 25 anos & 6 a $10 \mathrm{SM}$ \\
\hline 046 & Feminino & Ensino Médio & 16 a 25 anos & 6 a 10 SM \\
\hline 047 & Masculino & Ensino Médio & 16 a 25 anos & Até $5 \mathrm{SM}$ \\
\hline 048 & Feminino & Ensino Médio & 16 a 25 anos & Até $5 \mathrm{SM}$ \\
\hline 053 & Masculino & Superior & 16 a 25 anos & 6 a 10 SM \\
\hline 054 & Feminino & Superior & 16 a 25 anos & Até 5 SM \\
\hline 068 & Feminino & Ensino Fund. & 26 a 35 anos & 11 a 24 SM \\
\hline 069 & Masculino & Ensino Fund. & 26 a 35 anos & 6 a 10 SM \\
\hline 084 & Feminino & Superior & 26 a 35 anos & 11 a 24 SM \\
\hline 085 & Masculino & Superior & 26 a 35 anos & 6 a $10 \mathrm{SM}$ \\
\hline 091 & Masculino & Ensino Fund. & 36 a 55 anos & 11 a 24 SM \\
\hline 092 & Feminino & Ensino Fund. & 36 a 55 anos & 11 a 24 SM \\
\hline 109 & Masculino & Ensino Médio & 36 a 55 anos & 6 a 10 SM \\
\hline 110 & Feminino & Ensino Médio & 36 a 55 anos & 6 a $10 \mathrm{SM}$ \\
\hline 133 & Masculino & Ensino Fund. & + de 55 anos & 6 a 10 SM \\
\hline 134 & Feminino & Ensino Fund. & + de 55 anos & 6 a 10 SM \\
\hline 149 & Masculino & Superior & + de 55 anos & 6 a 10 SM \\
\hline 150 & Feminino & Superior & + de 55 anos & 6 a 10 SM \\
\hline
\end{tabular}

Quadro 2: Composição da subamostra da pesquisa 
Como vários estudos atestam que a concordância aparece mais em falantes que tiveram ou têm mais contato com a escola, optamos por estudar três níveis de escolaridade (Ensino Fundamental I e II, Ensino Médio e Ensino Superior) para verificarmos como a concordância ocorre em tais informantes. Excluímos renda familiar acima de 25 salários mínimos pelo fato de muitos trabalhos já terem atestado que quanto mais alta a classe econômica do informante mais concordância ele fará. Um dos nossos intuitos, nesse trabalho, é analisar grupos sociais intermediários para verificarmos como tal fenômeno se comporta, justamente, na camada propícia à mudança e à variação linguística.

A partir da seleção desses 24 informantes, a pesquisa foi feita procedendo-se ao levantamento de todas as ocorrências, nas quais haja, pelo menos, um dos elementos do SN no plural somado a um ou mais verbos. Para tanto serão excluídos os SNs com função predicativa e/ou outros SNs que não acompanharem verbo algum.

\subsection{COMPOSIÇÃO DO CORPUS DA MODALIDADE ESCRITA}

Nosso corpus da modalidade escrita está composto por mais de 600 redações escolares de alunos do ensino fundamental I, do ensino fundamental II e do ensino médio.

As redações escolares foram cedidas pelas escolas: Profo Oscar Arantes Pires, escola municipal de $1^{\circ}$ ao $5^{\circ}$ ano (ensino fundamental I) e pela escola estadual Prof ${ }^{\circ}$ Justino Jerry Faria, escola de $6^{\circ}$ ano ao $3^{\circ}$ colegial (ensino fundamental II e ensino médio). Ambas são escolas da cidade de São José do Rio Preto.

A Escola Municipal Prof. Oscar Arantes Pires está localizada à rua Imperial, bairro Ipiranga, muito próxima ao centro comercial da cidade de São José do Rio Preto. 
A escola foi fundada em 01/01/1998, estando capacitada para atender alunos do $1^{\circ}$ ao $5^{\circ}$ ano do ensino fundamental I (antigo ensino primário).

A Escola Estadual Prof. Justino Jerry Faria está localizada à rua Ipiranga, bairro Santos Dumont, muito próxima ao aeroporto da cidade de São José do Rio Preto. A escola está capacitada para ensinar alunos do $6^{\circ}$ ao $9^{\circ}$ ano (antigo ginásio) e alunos do $1^{\circ}$ ao $3^{\circ}$ ano do ensino médio. Ambas as escolas se encontram localizadas em bairros de classe média.

Tais escolas desenvolvem com seus alunos importantes projetos educacionais, por exemplo: Projeto Criança Leitora que tem acompanhamento da coordenação e da professora de língua portuguesa. Esse projeto vem sendo desenvolvido com sucesso há muitos anos. Projeto Jornal na Educação em parceria com o Diário da Região (Jornal da região de São José do Rio Preto), as professoras envolvidas recebem treinamento e instruções para depois fazerem a socialização de informações e o trabalho em classe com os jornais. Vemos que são projetos que estimulam o bom comportamento, bem como a leitura e produção textual. De modo que os alunos recebem um grande incentivo por parte de seus professores.

Mesmo sendo escolas da rede pública, vemos que são escolas preocupadas com a boa formação do seu aluno. Acreditamos que estes fatores extralinguísticos podem influenciar a aplicação da regra padrão da concordância verbal em textos escritos de tais alunos. Acreditamos que expor esse contexto situacional vivenciado pelos alunos possa ser importante para entendermos que um bom trabalho do professor vai além dos livros didáticos, pois, muitas vezes, é necessário vivenciar outras realidades linguísticas com o aluno, como, por exemplo, a leitura do jornal. Mostrar para o aluno como a concordância verbal se dá na escrita pode ser um bom exercício, talvez 
até melhor do que deixar o aluno decorando as regras e as exceções que envolvem o fenômeno da concordância verbal.

Os alunos do ensino fundamental I produziram duas narrativas, que apresentaram como tema a reescrita da história da "Branca de Neve e os Sete Anões" e o tema "Meus amigos". Já os alunos do ensino fundamental II produziram narrativas com os seguintes temas: "Uma viagem inesquecível" e "Minha festa de 15 anos". Os alunos do ensino médio produziram textos com os temas: "Consumo consciente de água" e "Porte de armas".

Os professores responsáveis pela disciplina de Língua Portuguesa nos cederam tais redações para analisarmos. Desse modo, os temas não foram propostos por nós, e sim pelos seus próprios professores de língua portuguesa. Acreditamos que, com isso, os alunos tenham se sentido menos constrangidos no momento da produção textual, uma vez que eles não sabiam que teriam suas redações analisadas.

Gostaríamos de lembrar que a escola cedeu de livre e espontânea vontade suas redações, expressando, por meio de um termo de declaração, sua adesão livre e consentida ao corpus de minha dissertação, cujos objetivos Ihes foram claramente explicitados. No final desta pesquisa, levaremos às escolas os resultados encontrados para a modalidade escrita, a fim de discutirmos como se encontra o processo de concordância verbal em tal modalidade, além de trabalharmos possíveis atividades acerca da concordância verbal.

Só nos resta agradecer a essas duas escolas e aos professores que foram muito prestativos conosco. Nosso muito obrigada. 


\subsection{VARIÁVEIS LINGUISTICAS E EXTRALINGUISTICAS}

A variação linguística é uma característica intrínseca das línguas naturais. $O$ suposto "caos" linguístico pode ser apenas aparente, tornando-se passível de sistematização. Isso porque os usos da língua estão ligados a fatores estruturais, internos à língua, e sociais, externos à língua, que agem conjuntamente no favorecimento ou até mesmo na supressão do uso de certas variantes. Está claro para todo pesquisador que inicia um estudo sociolinguístico que a língua muda com o tempo.

Um dos princípios mais claros da Teoria da Variação é o de que as línguas naturais estão em constante variação. Assim, a Sociolinguística Variacionista postula que as mudanças são apreendidas em seu curso de implementação, através do que se denominou análise em tempo aparente.

A partir do perfil de cada variante poderemos explorar os contextos mais favoráveis à aplicação da regra de concordância verbal. Dá-se o nome de envelope da variação à descrição detalhada das variantes em questão. Portanto, descreveremos, analisaremos e sistematizaremos o envelope de variação na realização da concordância verbal.

A presente pesquisa contempla o estudo com sujeitos simples (de um só núcleo) de estrutura simples de $3^{\text {a }}$ pessoa do plural representados por:

1. Nome substantivo no singular com um ou mais determinantes no plural: Doc.: os músico éØ melhor ${ }^{10}$ ? (AC 043, L. 187);

\footnotetext{
${ }^{10}$ Todos os exemplos, dessas variáveis linguísticas, foram retirados do corpus do banco de dados IBORUNA, da modalidade falada.
} 
2. Nome substantivo no plural acompanhado ou não de determinante no plural: que as meninas são bem próximas da dona N.(AC 047, L. 54-55);

3. Pronomes pessoais com referência determinada: aí eles foram tudo começô(u) dançá(r) (AC 054, L. 144);

4. Numeral com determinante no plural: agora os dois tão com raiva assim... (AC 043, L. 57);

5. Pronome demonstrativo com referência determinada: aqueles são meus ami::gos... (AC 012, L. 67).

Nossa variável dependente é binária, tanto para a modalidade falada quanto para a modalidade escrita, e constitui-se das seguintes variantes:

1. aplicação da regra de concordância verbal: ah eles são excelentes... professores... (AC 133, L. 420);

2. não aplicação da regra de concordância verbal: porque os filhos viaø o comportamento de::le... (AC 110, L. 107).

Nossa pesquisa tem por objetivo testar algumas das mais relevantes variáveis linguísticas e extralinguísticas encontradas em outros trabalhos que também se propuseram a estudar a concordância verbal na fala. Como nosso corpus é composto por um banco de dados da modalidade falada (IBORUNA) e por um banco de dados da modalidade escrita (redações escolares), queremos analisar quais variáveis são válidas tanto para a fala quanto para a escrita. 
Optamos por trabalhar com as seguintes variáveis linguísticas: paralelismo formal; traço semântico do sujeito; saliência fônica; a estrutura do sujeito; a posição que o sujeito ocupa com relação ao verbo; distância entre sujeito e verbo; o papel semântico do verbo e tipo de relato. E com as seguintes variáveis extralinguísticas: gênero/sexo; faixa etária; escolaridade e renda sócio-econômica.

Os SNs com função predicativa e os SNs que não se relacionam a verbo algum, não alterando, assim, a marca formal de plural de nenhum verbo, serão desconsiderados.

\subsubsection{PARALELISMO FORMAL ORACIONAL}

"Marcas levam a marcas e zeros levam a zeros" (Scherre, 1988), essa frase explicaria a tendência de formas gramaticais semelhantes ocorrerem juntas, já que há uma tendência de sujeito com marcas explícitas de plural se correlacionar a um verbo com tais marcas. Inversamente, um sujeito com marca zero de plural se correlacionará com um verbo com marca zero de plural. De modo que esperamos mais concordância verbal quando os SN-sujeitos também apresentarem marcas de plural explícitas.

Exemplificando, temos:

1. Presença de marca formal de plural no $1^{\circ}$ e único elemento do SN: No Andaló Chopp... eles foram lá:: deram um tempo (AC 043, L. 33);

2. Presença de marca formal de plural em dois ou mais constituintes do SN: tem ídolo do rock... atualmente... ou os ídolos já... ficaram pa trás? (AC 043, L. 216-217);

3. Ausência de marca formal de plural no elemento imediatamente anterior ao verbo: os:: paramédicoØ colocô(u) Ø a gente dentro do resga::te né? (AC 044, L. 19-20). 
Para esse fator, consideramos o último elemento do SN sujeito e analisamos se esse elemento traz ou não a marca explícita de plural.

\subsubsection{TRAÇO SEMÂNTICO DO SUJEITO}

O princípio básico que rege a frequência relativa do uso das variantes verbais formalmente marcadas para o plural no contexto de sujeitos plurais é sempre o mesmo: usam-se mais marcas em contextos em que a relação entre sujeito e verbo é mais saliente. Há três dimensões para a saliência: saliência da posição, saliência fônica da oposição singular/plural dos verbos e saliência do traço semântico do sujeito.

A hipótese sugerida é a de que sujeito humano leve o verbo para o plural em maior porcentagem do que os não-humanos.

Exemplificando, temos:

1. [-humano, +animado]: então... os cachorrinho tava chorando né?... então meu marido pegô eles (AC 110, L. 104);

2. [-animado]: e éh:: esses teatros... anTlgos de época... que apareceØ em televisão (AC 045, L. 224);

3. [+humano]: agora tem o(u)tras pessoas que éØ mais sossegada... (AC 047, L. 63);

4. [+humano]: No Andaló Chopp... eles foram lá:: deram um tempo (AC 043, L. 33).

\subsubsection{SALIÊNCIA FÔNICA}

Saliência fônica é a oposição entre as formas verbais do singular e do plural, especificamente as de terceira pessoa. A hierarquia da saliência fônica na relação 
singular/plural é estabelecida em função de dois critérios: presença ou ausência de acento na desinência e quantidade de material fônico que diferencia a forma singular da forma plural.

Considerando-se não somente a nasalidade, mas também outros traços fonéticos de diferenciação entre as formas singular e plural dos verbos em português, Lemle \& Naro (1977), em estudo sobre a concordância verbal, experimentaram três categorizações no estabelecimento dos níveis gradativos da escala de saliência fônica. Posteriormente, Naro (1981), em estudo minucioso dessa variável, propôs dois níveis básicos para o controle da variável, a saber: (1) diferenciação não-acentuada, isto é, pares em que os segmentos fonéticos que estabelecem a oposição, ou seja, não são acentuados nos dois membros e (2) diferenciação acentuada, ou seja, pares em que esses segmentos são acentuados em pelo menos um membro da oposição (NARO, 1981:74).

No entanto, ressaltamos que adotamos a mesma divisão feita por Rodrigues $(1988)^{11}$, segundo a qual o primeiro nível corresponde aos pares cujos segmentos fonéticos que realizam a oposição são inacentuados em ambos os membros, pois o acento recai no radical. Distinguem-se, nesse nível, duas classes ordenadas de acordo com a crescente diferenciação de material da oposição singular/plural. Pertencem a esse nível, os verbos regulares, cuja diferença entre singular e plural reside na nasalidade, por exemplo, come/comem; fala/falam. E os verbos cuja diferença entre singular e plural reside na presença de uma vogal final átona, possivelmente nasalada, por exemplo: faz/fazem; quer/querem. 
Já o segundo nível corresponde aos pares em que os segmentos fonéticos com valor mórfico são acentuados em pelo menos um membro da oposição. Todas as oposições do primeiro nível são menos salientes que qualquer uma do segundo nível. Distinguem-se, no nível dois, quatro classes que também se ordenam em função da diferenciação de material crescente da oposição singular/plural.

Inseridas no segundo nível, temos as classes dos elementos vocálicos tônicos orais no singular, em contraste com ditongo tônico nasal no plural, por exemplo, está/estão; vai/vão e dá/dão. A classe dos pretéritos perfeitos regulares onde, independentemente da conjugação, o acento recai na vogal temática: falou/falaram; vendeu/venderam; partiu/partiram. A dos pretéritos perfeitos irregulares, com variação do grau de abertura da vogal tônica, por exemplo, trouxe/trouxeram; fez/fizeram. E a classe em que os membros são totalmente distintos entre o singular e o plural: é/são (caso único).

Baseadas em tal hierarquia, vamos observar se em nosso corpus a presença da concordância verbal aumenta conforme o nível de saliência fônica se torna mais perceptível. Outros trabalhos atestaram que a concordância se realiza menos quando a diferença entre as formas de singular e plural se restringe à nasalidade, acompanhada ou não de mudança de qualidade da vogal átona final. Já, por outro lado, as categorias do segundo nível tendem a favorecer a concordância.

Da mesma forma como Lemle e Naro em 1977, Rodrigues em 1987, Scherre em 1988 e Cardoso em 2005, supomos que quanto mais saliente for a diferença fônica entre singular e plural, mais provável será a concordância, ou seja, a falta de

\footnotetext{
${ }^{11}$ Diferentes linguistas adotaram diferentes critérios para agrupar determinados verbos em classes distintas. Adotamos a mesma divisão da linguista Rodrigues por nos parecer uma das divisões mais
} 
concordância ocorre tanto mais quanto menos ela se faz sentir, o que nos evidencia que o uso das formas padrão depende diretamente do grau de perceptibilidade dos efeitos fonéticos que ela acarreta.

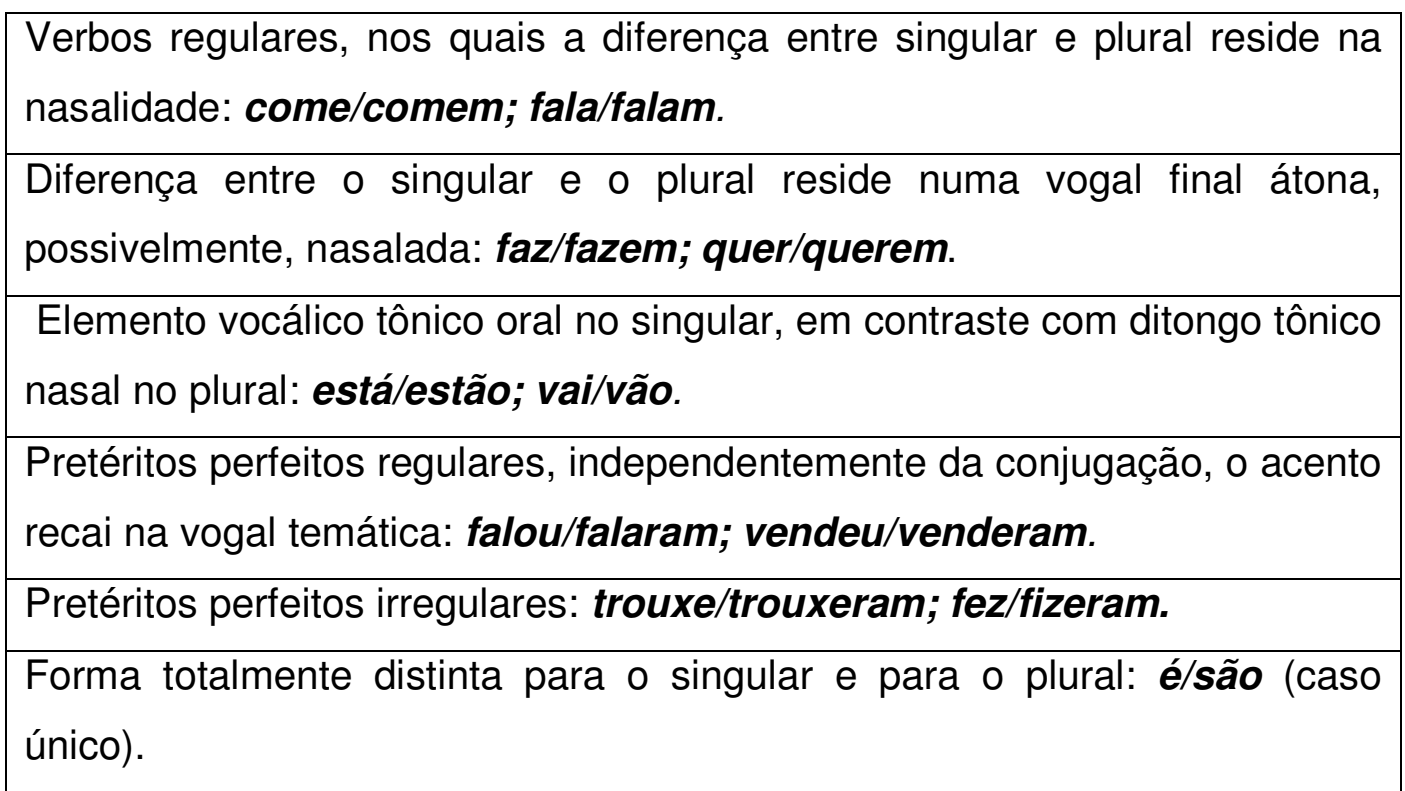

Quadro 3: Variável saliência fônica verbal

\subsubsection{ESTRUTURA DO SUJEITO}

Consideramos a possibilidade de se estabelecer uma relação entre a aplicação da regra padrão e a constituição do sujeito. Decidimos elaborar este grupo de fatores a partir das ocorrências encontradas em nosso corpus, pois dessa maneira poderíamos observar como se manifesta a concordância verbal a depender da estrutura do sujeito.

Segundo Scherre (1988), a estrutura sintagmática composta desfavorece a presença de SNs totalmente marcados, desfavorecendo assim o uso das marcas verbais. E, segundo Rodrigues (1988), o sujeito apagado tende a se relacionar, na 
maioria das vezes, com a forma verbal marcada em número e pessoa, ao contrário do sujeito explícito, que tende a favorecer a não aplicação da regra da concordância verbal.

Exemplificando, temos:

1. Nome substantivo no singular com um ou mais determinantes no plural: Doc.: os músico éø melhor ${ }^{12}$ ? (AC 043, L. 187);

2. Nome substantivo no plural acompanhado ou não de determinante no plural: que as meninas são bem próximas da dona N.(AC 047, L. 54-55);

3. Pronomes pessoais com referência determinada: aí eles foram tudo começô(u) dançá(r) (AC 054, L. 144);

4. Numeral com determinante no plural: agora os dois tão com raiva assim... (AC 043, L. 57);

5. Pronome demonstrativo com referência determinada: aqueles são meus ami::gos... (AC 012, L. 67).

\subsubsection{DISTÂNCIA E POSIÇÃO DO SUJEITO COM RELAÇÃO AO VERBO}

Com esta variável, medimos, em número de sílabas, a distância entre sujeito e verbo. Nossa hipótese é a de que quanto mais óbvia ou mais saliente for a relação sujeito/verbo, maior será o percentual de concordância verbal. Dessa forma, quanto mais perto estiver o sujeito do verbo a que se refere, esperamos encontrar um favorecimento à aplicação da regra. Inversamente, quanto mais distante o sujeito

\footnotetext{
12 Todos os exemplos, dessas variáveis linguísticas, foram retirados do corpus do banco de dados IBORUNA, da modalidade falada.
} 
estiver do seu respectivo verbo, esperamos encontrar um percentual menor de concordância.

Exemplificando, temos:

1. Imediatamente anterior ao verbo: e:: eles viviam viajando... (AC 045, L. 185);

2. Imediatamente posterior ao verbo: chegouØ os médicos:: (AC 021, L. 141);

3. Material interveniente com até quatro sílabas: as pessoas sempre estavam tristes... agora não (AC 085, L. 109);

4. Mais de quatro sílabas: as mesas:.... mais ou menos... prontas pra... serem separadas (AC 013, L. 180).

Sabemos que os vínculos sintáticos entre sujeito e verbo ficam mais salientes quando o sujeito determinante antecede imediatamente o verbo determinado. Quando o sujeito sucede o verbo, sua relação fica menos saliente, tornando a concordância menos óbvia e, portanto, apresentando menor probabilidade de aplicação da regra, porque quando o sujeito está posposto ao verbo, ele, muitas vezes, não se identifica como sujeito, mas sim como objeto direto do verbo.

Outros trabalhos já realizados sobre a concordância verbal atestaram que quando o sujeito é posposto ao verbo, independentemente da sua classe gramatical, a concordância praticamente não se realiza; a não concordância, nesses casos, é regra quase categórica. 


\subsubsection{PAPEL SEMÂNTICO DO VERBO}

Antes de discorrermos sobre o papel semântico do verbo, vamos defini-lo, utilizando a acepção de Borba (1991) que o caracteriza como unidade léxico-semântica. O verbo é o suporte das categorias de tempo, modo, número e pessoa.

Sabemos ainda que diferentes tipos verbais selecionam diferentes argumentos para figurarem como sujeitos da sentença e para determinar a posição que este sujeito irá ocupar. Os verbos que apresentam tendência a selecionar argumentos com o traço mais humano, para figurarem como sujeito na sentença, tenderiam a uma maior marcação da concordância. O mesmo acontece com a cópula que, ao selecionar um argumento diretamente relacionado ao sujeito, o predicativo do sujeito, também favoreceria a presença da concordância verbal.

Certamente, já é sabido que a questão do funcionamento verbal é objeto para um grande e longo projeto de pesquisa. Por esta razão, limitamos a pesquisa realizada, para este trabalho, aos fatos devidos à construção e estruturação do discurso.

Segundo Borba (1996), da associação entre um verbo e um nome resulta um caso para o nome e uma classe para o verbo, de modo que há quatro classes sintáticosemânticas de verbos, a saber: verbos de ação, de processo, de ação-processo e de estado.

Os verbos de ação expressam uma atividade realizada por um sujeito agente, ou seja, indicam um "fazer" por parte do sujeito:

1. tem as mesinhas onde os alunos lan::cham... e a... (AC 013, L. 71-72);

2. assim eles pulam das árvores (AC 045, L. 243). 
Os verbos de processo expressam um evento ou sucessão de eventos que afetam um sujeito paciente ou experimentador, de modo que sempre traduzem algo que se passa com o sujeito ou algo que o sujeito experimenta:

3. daí as brigas pararam não? (AC 053, L. 359);

4. mas de noite:: eles acordaram e tudo acabou (AC 092, L. 67);

5. eles ouvem bem:: mas já são velhinhos... (AC 109, L. 470).

Os verbos de processo admitem especificadores como na seguinte frase: [6: ouvem bem.].

Segundo Decat (1983), para identificarmos um verbo de ação, devemos perguntar "o que fez N?" Já para identificarmos um verbo de processo, perguntamos "o que aconteceu a N?"

Já os verbos de ação-processo expressam uma ação realizada por um sujeito agente, aquele que pratica uma ação, porém tal ação recairá sobre o complemento verbal, modificando um estado, uma condição ou uma posição que antes não existia. Isto é, as entidades envolvidas em uma descrição sofrem uma transformação, alteração, uma passagem de um estado para outro. Por isso, os verbos de açãoprocesso são também chamados de mudança de estado ou causativos. Por exemplo:

6. daí eles quebraram tudo lá:: (AC 013, L. 102);

7. ma::s eles escreveram um livro... você sabe não? (AC 109, L. 286);

8. mas as empregadas estragaram as crian:::ças... ( AC 013, L. 177). 
Os verbos de estado expressam uma propriedade, isto é, um estado, uma condição ou uma situação localizada no sujeito que é apenas um suporte de tal propriedade. Tais verbos têm obrigatoriamente um argumento que não é agentivo, nem causativo, nem paciente. Suas entidades envolvidas numa descrição não sofrem qualquer alteração ou transição durante um intervalo de tempo. Segundo Travaglia (1991), o estado é sempre um predicativo. Também são denominados verbos copulativos, predicativos ou de ligação já que são verbos que unem o núcleo do predicado, o predicativo ao sujeito. Exempilicando, temos:

9. as pessoas sempre estavam tristes... agora não (AC 085, L. 109);

10. nessa sala... as mesas são todas padronizadas (AC 091, L. 170-171);

11. muito organiZAda... as/ os/ avenidas as avenidas são largas sabe bem:: (AC 045, L. 251-252)

Com o auxílio do programa estatístico GOLDVARB-X, saberemos qual é o comportamento dessa variável e até que ponto ela influencia na aplicação da regra da concordância verbal.

\subsubsection{TIPO DE RELATO}

Para esta variável não temos nenhuma hipótese, uma vez que outros bancos de fala não apresentam tais tipos de relato (narrativa de experiência pessoal, narrativa recontada, relato descritivo, relato de procedimento e relato de opinião). Como o banco de dados IBORUNA está composto por cinco tipos de relatos diferentes, optamos por 
explorar tal divisão. Queremos com o estudo de tal variável, averiguar se algum tipo de relato propicia a aplicação da concordância verbal.

\subsubsection{SEXO/GÊNERO}

Inúmeros estudos mostraram que há uma tendência de as mulheres usarem a variedade linguística de prestígio ou dela se aproximarem, com mais frequência do que os homens. Talvez pelo fato de as mulheres se mostrarem mais receptivas à atuação normatizadora da escola e também por serem mais afeitas ao uso das formas mais conservadoras. Ou também pela pressão que sofrem em ter um comportamento mais correto do que os homens.

No corpus estudado por Rodrigues (1987), o gênero não constitui fator social relevante no condicionamento da concordância verbal de $3^{\underline{a}}$ pessoa do plural. Nossa hipótese é a de que o gênero não é uma variável relevante para o fenômeno em questão, também na comunidade por nós estudada. Mesmo assim, consideramos importante averiguar essa tendência para nos posicionarmos melhor diante da hipótese formulada.

\subsubsection{FAIXA ETÁRIA}

Como outros trabalhos, como, por exemplo, os de Monguilhott (2001 e 2009) e de Vieira (1995), já mostraram que os jovens têm aplicado mais a regra de concordância verbal, acreditamos que estamos diante de um momento de aplicação da regra, já que a variável 7-15 anos tem se mostrado mais propícia ao uso da regra padrão. Teríamos então uma mudança em favor do uso da regra, talvez pelo fato de a 
escola evidenciar o estigma que uma frase sem concordância traz consigo, já que os falantes nessa faixa etária ainda estudam.

Portanto, queremos analisar, em nossa pesquisa, como tal variável se comporta. Será que a faixa etária mais jovem é também, em nossa região, a que mais concordância faz? Para tanto serão controladas as seguintes variáveis:

\begin{tabular}{|c|}
\hline 7-15 anos. \\
\hline 16-25 anos. \\
\hline $26-35$ anos. \\
\hline 36-55 anos. \\
\hline Mais de 55 anos. \\
Quadro 4: Variável faixa etária
\end{tabular}

\subsubsection{ESCOLARIDADE}

Em que medida a escolaridade dos informantes influencia na aplicação da regra de concordância verbal? Sabemos que a escola transmite a norma padrão, preconizando a flexão verbal. Segundo Scherre (1988), está comprovado que a escola é a principal instituição que preza pelo ensino da norma culta ou de maior prestígio social e, por isso, quanto maior for o grau de escolarização do falante, mais probabilidade ele terá de aplicar a regra plural no $\mathrm{SN}$ e no verbo.

Essa variável sociolinguística pode estar correlacionada à variável classe socioeconômica, já que se espera que a classe média-alta apresente níveis de escolaridade mais elevados, de tal forma que os mais escolarizados tenderão a usar a variante de prestígio, e, consequentemente, haverá uma frequência menor de uso da 
variante estigmatizada. Já os informantes menos escolarizados tenderiam a usar a variante desprestigiada ou estigmatizada com maior frequência do que os segmentos escolarizados.

Portanto, acreditamos que quanto menos escolarizado for o falante, menores serão suas chances de aplicar a regra padrão de concordância verbal. Na modalidade falada, dividimos esse grupo de fatores em:

\begin{tabular}{|l|}
\hline Ensino fundamental I e II. \\
\hline Ensino médio. \\
\hline Ensino superior. \\
\hline
\end{tabular}

Quadro 5: Variável escolaridade na modalidade falada

Já na modalidade escrita, não trabalhamos com a escolaridade ensino superior, já que a produção de redações, nesse nível, não acontece com frequência. Para essa modalidade dividimos esse grupo de fatores em:

\begin{tabular}{|l|}
\hline Ensino fundamental I. \\
\cline { 2 - 2 } \\
\hline Ensino fundamental II. \\
\hline Ensino médio. \\
\hline Quadro 6: Variável escolaridade na modalidade escrita
\end{tabular}

\subsubsection{RENDA SÓCIO-ECONÔMICA}

Sabemos que a posição que o sujeito ocupa na sociedade influencia muito a sua maneira de falar. Pessoas mais humildes tendem a aplicar menos a regra padrão da 
concordância. Já um indivíduo de uma classe social mais alta, tende a utilizar a variante padrão, de prestígio. O que nos comprova que as forças sociais estão no comando do fenômeno analisado. Estudos na área têm salientado que os grupos socioeconômicos intermediários frequentemente adiantam o processo, uma vez que eles têm maior consciência da variação estilística, bem como da importância socialmente atribuída a cada uma das variantes em questão.

Segundo Scherre (1988), a aplicação da regra é diretamente proporcional ao nível social e de escolarização dos informantes, ou seja, quanto mais altos forem o nível social e de escolarização dos informantes, mais a regra se aplica, quanto mais baixos, menos ela se aplica. Nosso grupo de fatores está dividido da seguinte maneira:

$$
\begin{array}{|l|}
\hline \text { Até } 5 \text { salários mínimos. } \\
\hline \text { De } 6 \text { a } 10 \text { salários mínimos. } \\
\hline \text { De } 11 \text { a } 24 \text { salários mínimos. } \\
\text { Quadro 7: Variável renda sócio-econômica }
\end{array}
$$

Através de uma decodificação, na qual analisamos todas as ocorrências encontradas de acordo com os grupos de fatores elencados por nós, os dados foram inseridos no pacote de programas computacional GOLDVARB-X que realizou os cálculos estatísticos. A partir desses cálculos, elaboramos as tabelas e gráficos que dão suporte para a análise quantitativa e qualitativa dos nossos dados.

O programa computacional Goldvarb-x é uma nova versão da ferramenta metodológica fundamental da Sociolinguística Variacionista - o programa de regra variável. Esse programa foi desenvolvido para ajudar a análise quantitativa de fenômenos linguísticos variáveis. 
O nível de significância utilizado pelo programa é de 0,05 , o que quer dizer que a probabilidade que o resultado apresentado seja verdadeiro é de $95 \%$. Outras informações dadas em cada rodada são o input, que é a medida global corrigida, isto é, a probabilidade de ocorrência da variável selecionada sem levar em conta o efeito dos fatores; a verossimilhança ou log likelihood, que é uma medida de quanto um resultado em particular é adequado ao comportamento real da variável. Na análise que fizemos, analisamos os percentuais e os pesos relativos gerados pelo programa.

O Goldvarb-x ainda nos mostra os pesos relativos de cada variável linguística e extralinguística. Os pesos relativos inferiores a 0.5 são interpretados como desfavorecedores em relação ao uso da variável, os pesos relativos maiores que 0.5 são favorecedores. $E$ os que se encontram próximos à margem de 0.5 são considerados como neutros, ou seja, não influenciam muito em relação ao uso da variável.

Qual o elemento, na estrutura da frase, que é o responsável pela aplicação da regra de concordância verbal: o SN sujeito? O SN imediatamente antes do verbo? A Saliência fônica? O paralelismo formal oracional? Para responder estas perguntas contamos com o auxílio do programa estatístico computacional GOLDVARB-X, cujos resultados serão expostos na seção seguinte. A partir destes cálculos, elaboramos as tabelas e gráficos que dão suporte para a análise quantitativa dos dados. Cabe a nós interpretar os resultados e formular hipóteses diante da sensibilidade do fenômeno investigado à luz da teoria Sociolinguística. 


\section{ANÁLISE DOS DADOS DA MODALIDADE FALADA}

Neste capítulo, apresentamos os resultados dos cálculos estatísticos realizados pelo programa computacional GOLDVARB-X.

Os gráficos e as tabelas apresentados a seguir exibem o percentual de aplicação da regra padrão de concordância verbal de acordo com os fatores elencados no capítulo que trata dos procedimentos metodológicos.

Vale frisar ainda que a disposição destes gráficos e tabelas segue a ordem de relevância estatística estabelecida pelo programa GOLDVARB-X.

Analisamos, para a modalidade falada, um total de 1397 ocorrências de concordância verbal, sendo 1183 ocorrências de aplicação da regra, o que resulta em $85 \%$ de presença de CV no corpus analisado.

O gráfico apresentado a seguir exibe o percentual de aplicação da regra padrão de concordância verbal de acordo com os grupos de fatores elencados no capítulo anterior.

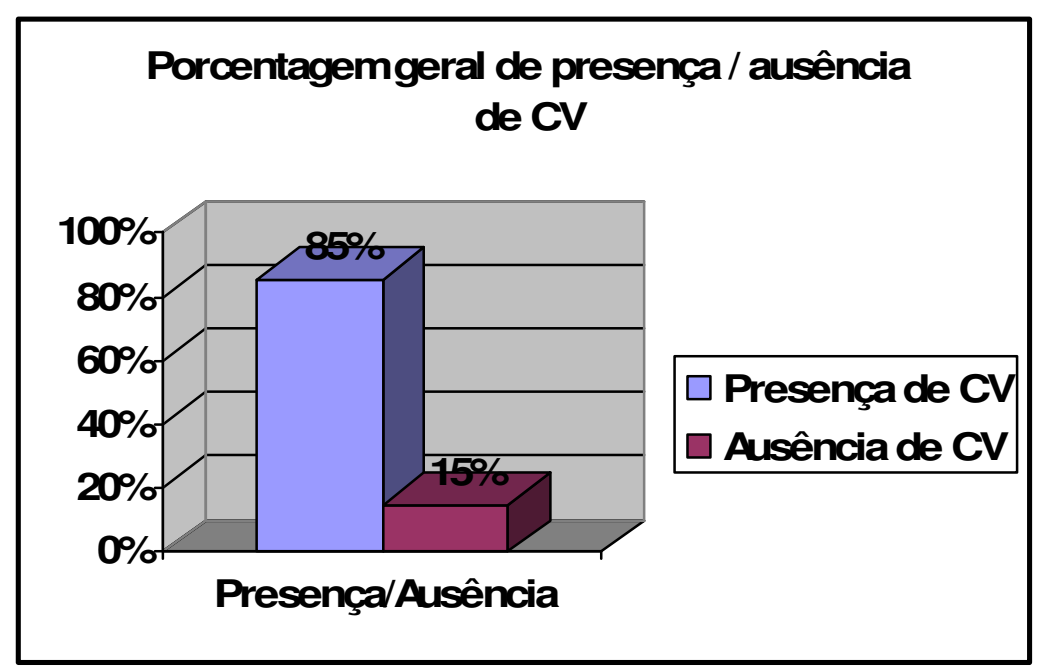

Gráfico 3: Porcentagem total de aplicação da regra de CV na modalidade falada 
Os resultados dos cálculos estatísticos evidenciam que a concordância verbal na modalidade falada na região noroeste do Estado de São Paulo encontra-se em variação e que está havendo um predomínio do uso da regra padrão.

Os grupos de fatores selecionados pelo programa GOLDVARB-X em ordem de significância foram:

1) paralelismo formal;

2) distância e posição do sujeito;

3) faixa etária;

4) escolaridade;

5) saliência fônica;

6) estrutura do sujeito.

Os grupos de fatores excluídos pelo programa foram:

1) traço semântico do sujeito;

2) tipo de relato;

3) renda sócio-econômica;

4) gênero/sexo;

5) papel semântico do verbo.

Não só em nosso trabalho encontramos um percentual favorável ao uso da regra padrão de concordância verbal como também em outros trabalhos como em Scherre e Naro (1993) que apresentam resultados de um estudo da concordância verbo/sujeito em uma amostra constituída pela fala de 64 falantes residentes no Rio de Janeiro, com diferentes graus de escolaridade: primário, ginásio e colegial; homens e mulheres; adultos e crianças, além de três faixas etárias diferentes, a saber: 15-25 anos, 26-49 
anos e 50-71 anos. Tal amostra pertence ao corpus PEUL, Programa de Estudos sobre o Uso da Língua.

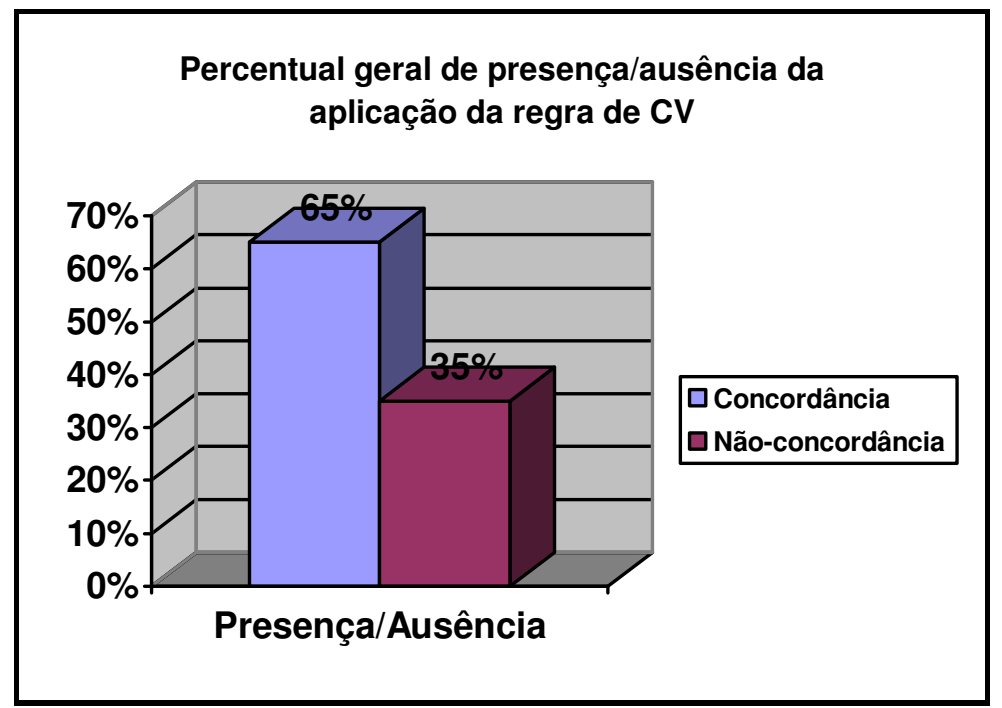

Gráfico 4: Porcentagem geral de presença/ausência de CV (resultados de Scherre e Naro, 1993)

O percentual de $65 \%$ de concordância nos revela que há um predomínio das devidas marcas de plural.

Vieira (1995), em sua dissertação de mestrado, estudou a concordância verbal da $3^{\mathrm{a}}$ pessoa do plural na fala de pescadores norte-fluminenses, com dados do Projeto APERJ - Atlas Etnolinguístico dos Pescadores do Estado do Rio de Janeiro. 


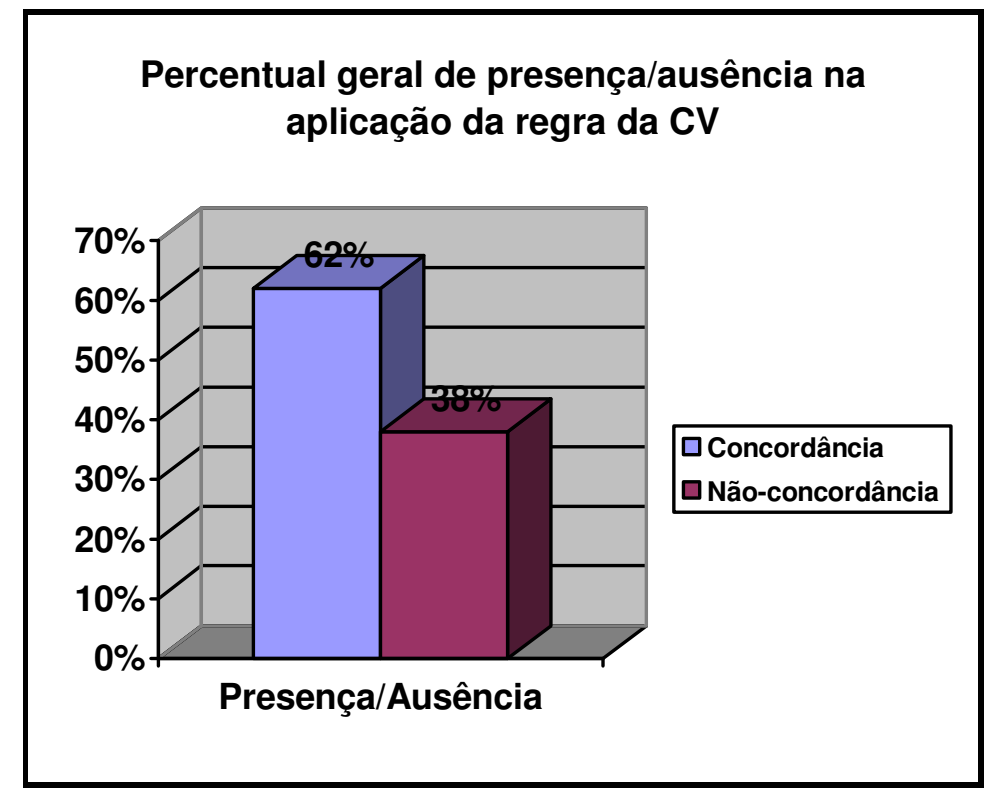

Gráfico 5: Porcentagem geral de presença/ausência de CV (resultados Vieira, 1995)

Não podemos ignorar o fato de que há um predomínio da norma-padrão, mesmo apresentando uma diferença menor entre a presença ou ausência da concordância verbal (apenas 24\%) que a dos nossos resultados, vale a pena frisar que Vieira estudou a fala de pescadores homens norte-fluminenses com pouca escolaridade, já que os informantes cursaram,no máximo, até a $4^{\text {a }}$ série/5ํㅡㅁ ano do primeiro grau. Acreditamos que este seja um dos motivos que faz com que a diferença entre presença/ausência de concordância verbal seja menor que a dos nossos resultados.

Comparando os resultados de Scherre e Naro (1993) e Vieira (1995), encontramos uma diferença de apenas 3\% de aplicação da regra, uma vez que Scherre e Naro (1993) encontraram um percentual de 65\% de aplicação da CV e Vieira (1995), $62 \%$. Acreditávamos que a baixa escolaridade dos informantes de Vieira era um dos "agentes" que inibia a ocorrência da CV em 38\%. No entanto, ao nos depararmos com 
os resultados de Scherre e Naro, que estudaram a fala de informantes com diferentes níveis de escolaridade, nossa hipótese inicial perde suas forças.

Entretanto não podemos deixar de mencionar a idéia de fluxo e contrafluxo de Naro e Scherre (1991), a qual versa a respeito da recorrência de um mesmo fenômeno linguístico em uma mesma época, ou seja, ambas as pesquisas aconteceram na década de 90 e apresentam um percentual, tanto de aplicação quanto de não-aplicação da regra de $\mathrm{CV}$, muito próximo, indicando, talvez, o começo de um fluxo que segue em direção à presença das marcas de plural. Esse fluxo seguiu e, no ano de 2009, com nossa pesquisa e com a pesquisa de Monguilhott, apresentada abaixo, vemos que 0 uso da norma-padrão está se instalando cada vez mais na fala das pessoas.

Monguilhot (2009), em sua tese de doutorado, investigou a variação na concordância verbal de terceira pessoa do plural sincrônica e diacronicamente, a partir de amostras do PB e do PE. A amostra sincrônica constitui-se de 32 entrevistas, sendo 16 realizadas com informantes de Florianópolis (representando a fala do Português Brasileiro) e 16 de Lisboa (representando a fala do Português Europeu). A amostra diacrônica compõe-se de 10 peças de teatro do século XIX e 18 do século XX, sendo a metade escrita por autores catarinenses (PB) e a outra metade escrita por autores portugueses (PE). 


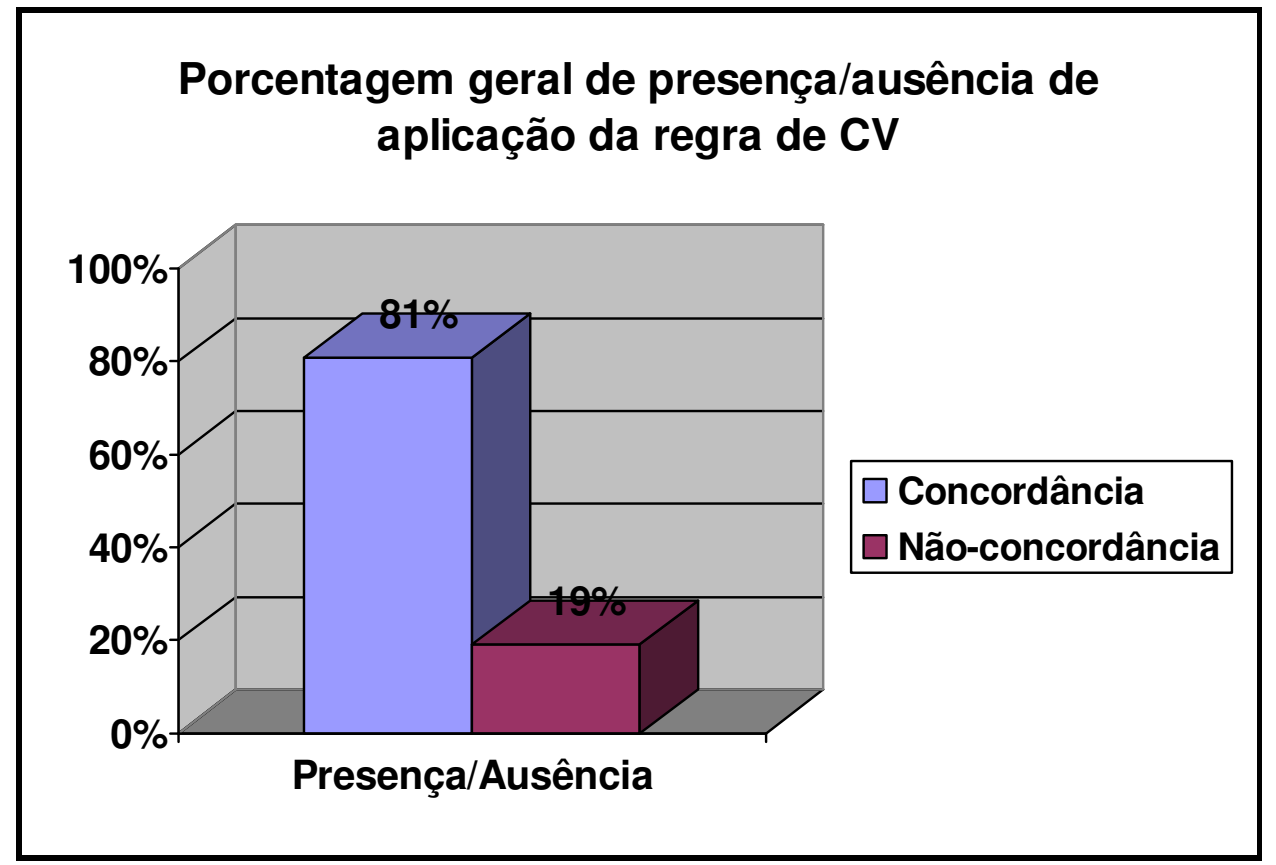

Gráfico 6: Porcentagem geral de presença/ausência de CV (resultados de Monguilhott para a amostra sincrônica do PB, 2009)

O percentual geral de presença de concordância verbal levanta uma questão interessante, que poderia ser formulada da seguinte maneira: os fatores externos, como o estigma social que a ausência de concordância verbal carrega e a pressão da escolaridade, seriam fatores sociais influenciando a conservação da regra padrão?

A ênfase da nossa análise recairá nos fatores selecionados, mas não deixaremos de discutir os não-selecionados, pois os cruzamentos desses fatores com os considerados estatisticamente mais relevantes nos revelam fatos importantes.

Antes de iniciarmos, julgamos importante comentar que a variável renda econômica de até 5 salários mínimos apresentou 20 ocorrências em nosso corpus, tendo $100 \%$ de aplicação da regra de concordância verbal. Como os programas que geram o cálculo do peso relativo não trabalham com fatores sem variação, ou seja, quando temos um knockout, foi necessário "eliminar" tal ocorrência. 
Vejamos os resultados de cada grupo de fatores selecionado em ordem de relevância.

\subsection{PARALELISMO FORMAL ORACIONAL}

A variável paralelismo formal se comportou de maneira esperada: marcas levam a marcas e zeros levam a zeros, pois a presença de $-s$ no $\mathrm{SN}$ antecedente ao verbo favoreceu o uso da concordância verbal. O fator marca de plural antecedente no primeiro e único elemento do $S N$ apresentou um percentual de aplicação da regra de 91\%. Ilustrando esse fator, temos:

1. aí eles foram na casa do M. (AC 043, L. 36-37);

2. faz tem::po... que eles separaram... (AC 012, L. 219);

3. então eles armaram né? (AC 69, L. 79).

O fator marca de plural antecedente em dois ou mais elementos do SN apresentou um percentual de aplicação de CV de 94\%. Exemplificando:

1. as cordas são contadas de ba(i)xo pra cima assim:: (AC 043, L. 115);

2. porque... as crianças dormem:: lá (AC 046, L. 298);

3. a::i... meus aMIgos falam das viagens de::les (AC 012, L. 67).

A ausência de plural antes do verbo apresentou um percentual de, apenas, $52 \%$ de aplicação da regra e 0.07 de peso relativo. 
1. os músico é melhor? (AC 043, L. 187);

2. os:: paramédico colocô(u) a gente dentro do resga::te né? (AC 044, L.19-20);

3. vira e mexe assim os cara ia lá... (AC 044, L.105).

\begin{tabular}{|c|c|c|}
\hline PARALELISMO FORMAL & FREQUÊNCIA & PESO RELATIVO \\
\hline $\begin{array}{c}\text { MARCA DE PLURAL } \\
\text { ANTECEDENTE NO 1ㅇ E } \\
\text { ÚNICO ELEMENTO DO SN }\end{array}$ & $912 / 1003=91 \%$ & $0.60^{13}$ \\
\hline $\begin{array}{c}\text { MARCA DE PLURAL } \\
\text { ANTECEDENTE EM DOIS } \\
\text { OU MAIS ELEMENTOS DO } \\
\text { SN }\end{array}$ & $150 / 160=94 \%$ & 0.75 \\
\hline MARCA ZERO & $121 / 234=52 \%$ & 0.07 \\
\hline ANTECEDENTE & & \\
\hline
\end{tabular}

TABELA 1: APLICAÇÃO DA REGRA - PARALELISMO FORMAL

Essa probabilidade de ausência de concordância vai diminuindo conforme vão aumentando as marcas de plural nos SNs.

Do que se observa, foi confirmada a hipótese de que a ausência da marca de plural no último elemento do SN sujeito favorece a não-concordância de modo considerável 0.07. Já a presença da marca de plural em SNs constituídos de um só vocábulo ou mais de um vocábulo favorece a presença da marca de número em 0.60 e 0.75, respectivamente. O efeito do paralelismo revela-se, portanto, ainda maior nos casos que contêm mais de uma marca de plural.

\footnotetext{
${ }^{13}$ A probabilidade ou o peso relativo abaixo de 0.5 favorece a não-aplicação da regra de concordância verbal, já quando o peso relativo se encontra acima de 0.5 favorece a aplicação da regra. Pelo fato de termos encontrado em nossa pesquisa um percentual maior de aplicação da regra, trabalharemos com os percentuais de presença de concordância verbal.
} 
Sendo assim, a tabela 1 nos evidencia que a concordância é controlada pelo princípio do paralelismo, uma vez que a ausência de plural no último constituinte do SN favorece a ausência de plural no verbo, resultando na não-aplicação da regra padrão.

No princípio do paralelismo, as formas gramaticais tendem a ocorrer juntas, assim, se há marcas de plural no sintagma nominal também haverá no verbo. Ao contrário, se não houver tais marcas no sintagma nominal, também haverá uma tendência de elas não ocorrerem no sintagma verbal. Segundo Scherre (1988), tal repetição das marcas gramaticais parece ter um caráter mecânico, as pessoas fazemna automaticamente, seria, portanto, uma força interna na língua.

Monguilhot (2001) analisou a concordância verbal em uma amostra de língua falada pertencente ao Projeto Varsul (Variação Linguística Urbana na Região Sul), composta de 24 florianopolitanos estratificados de acordo com idade, sexo e escolaridade.

Cardoso (2005), em sua dissertação, estudou a fala de uma mulher de 40 anos, branca, católica, casada, mãe de dois filhos e empregada doméstica. A informante frequentou a escola rural por três anos, é natural de Baixão das Porteiras, zona rural do interior do Maranhão. Atualmente, ela vive em um bairro da periferia do Distrito Federal, perto de Planaltina - Góias. Tal estudo constatou que a concordância verbal se comportou como uma regra variável.

Trago abaixo os resultados de Vieira (1995), Monguilhott (2001) e Cardoso (2005) acerca do grupo de fatores paralelismo formal oracional. 


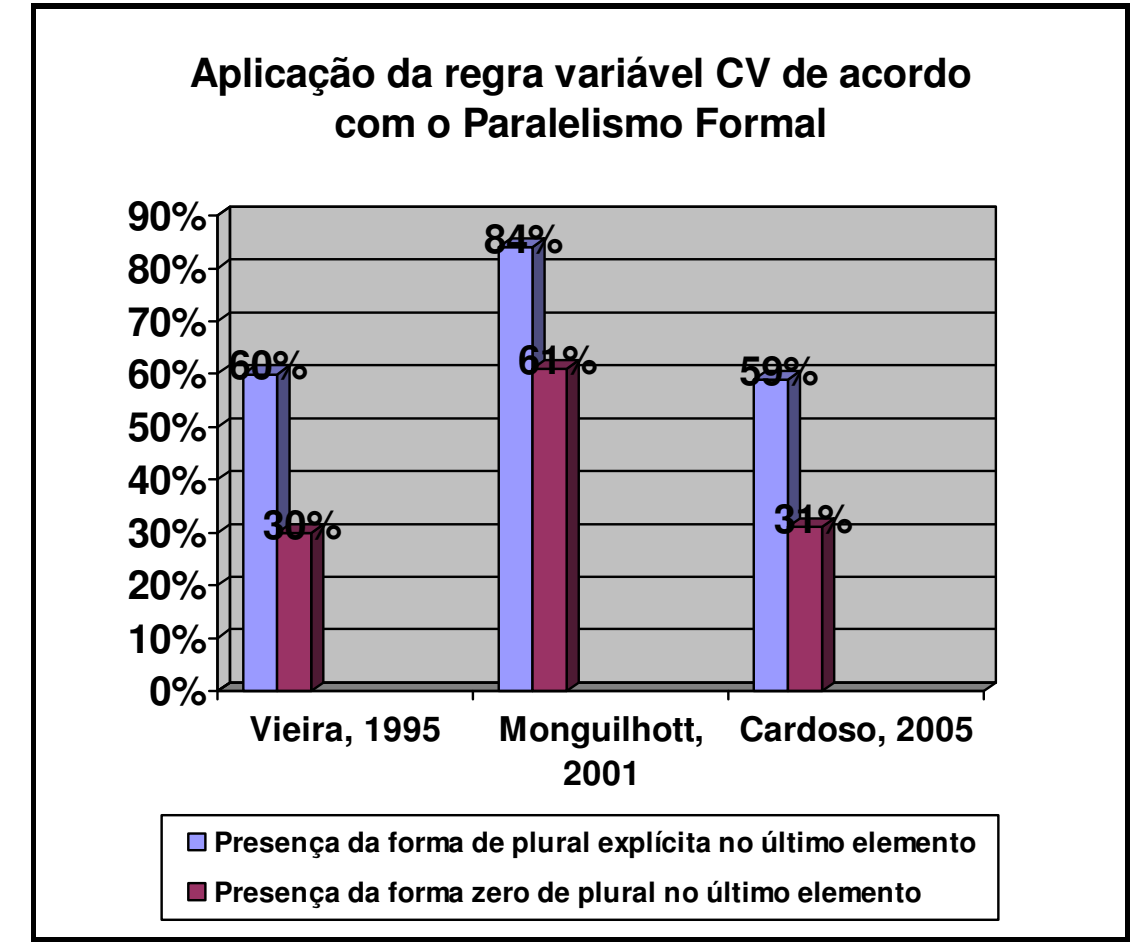

Gráfico 7: Aplicação de CV segundo a variável paralelismo formal: comparação entre os resultados de Monguilhott, 2001; de Cardoso, 2005 e de Vieira, 1995.

Mesmo Cardoso (2005) tendo estudado a fala de apenas uma informante, vemos que a variação também, neste caso, se fez presente. Nosso intuito ao comparar os resultados de Cardoso com os de outros linguistas, inclusive com os nossos resultados, está na intenção de verificar como a variação linguística acerca do fenômeno da CV se manifesta em estudos que envolvem vários informantes e em estudo que envolve apenas um informante. E, como podemos observar, no gráfico acima, a variação em um único indivíduo se manifesta de maneira semelhante aos demais estudos, nos quais há um predomínio de plural quando temos presença da forma plural explícita no último elemento do SN.

Com a visualização oferecida pelo gráfico 7, verifica-se, claramente, que as hipóteses levantadas neste trabalho foram confirmadas. A probabilidade de aplicação 
da regra de concordância aumenta à proporção que os SNs sujeitos apresentam marcas formais de plural.

Para o grupo de fatores paralelismo formal, a hipótese inicial foi confirmada, já que a presença de marcas de plural no último ou único elemento do SN-sujeito levou a uma maior frequência de preservação das marcas de concordância nos verbos. Tal resultado confirma a tendência de que marcas levam a marcas.

Este grupo de fatores confirmou a expectativa de que, por um lado, quando o último ou único elemento do SN apresentasse marca explícita de plural, o verbo também apresentaria tendência à pluralização, assim como a presença de plural também influenciaria na marcação do plural e de que, por outro lado, quando houvesse presença de zero no último elemento, haveria o desfavorecimento da forma de plural no verbo. Tais resultados confirmaram o princípio do paralelismo de "formas gramaticais particulares ocorrerem juntas" (Scherre, 1998, p. 42).

A variável paralelismo formal foi o primeiro grupo de fatores selecionado pelo Goldvarb-x. Portanto, estatisticamente, é o grupo de fatores mais importante dentre os demais grupos analisados. De modo que realizamos o cruzamento dos demais grupos de fatores com o paralelismo formal, a fim de verificar como se comportam as demais variáveis com a variável estatisticamente mais relevante.

\subsection{VARIÁVEL DISTÂNCIA E POSIÇÃO ENTRE SUJEITO E VERBO}

Considerando que o português é uma língua do tipo SVO (sujeito + verbo + objeto), que admite variação nesse padrão de ordenação, admitimos para este grupo de fator distância do sujeito a possibilidade de ele ser imediatamente anterior ou posterior ao verbo. 
Esta variável mostrou-se importante, em nosso trabalho, para a aplicação/nãoaplicação da regra de concordância verbal. Vejamos os resultados obtidos com os cálculos extraídos do programa GOLDVARB-X.

\begin{tabular}{|c|c|c|}
\hline DISTÂNCIA DO SUJEITO & FREQUÊNCIA & PESO RELATIVO \\
\hline $\begin{array}{c}\text { IMEDIATAMENTE } \\
\text { ANTERIOR }\end{array}$ & $351 / 407=86 \%$ & 0.38 \\
\hline $\begin{array}{c}\text { IMEDIATAMENTE } \\
\text { POSTERIOR }\end{array}$ & $25 / 38=66 \%$ & 0.19 \\
\hline $\begin{array}{c}\text { MATERIAL } \\
\text { INTERVENIENTE ATÉ 4 } \\
\text { SÍLABAS }\end{array}$ & $167 / 206=81 \%$ & 0.51 \\
\hline MAIS DE 4 SÍLABAS & $121 / 125=97 \%$ & \\
\hline
\end{tabular}

TABELA 2: APLICAÇẤO DA REGRA - DISTÂNCIA E POSIÇÃO DO SUJEITO

Esse grupo de fatores se comportou de maneira contrária à esperada por nós, pois esperávamos que houvesse um favorecimento de aplicação da regra quando o sujeito estivesse imediatamente anterior ao verbo, o que não aconteceu, uma vez que essa variável foi justamente uma das variáveis mais propícias para a não-aplicação da regra de CV. Abaixo trazemos alguns exemplos extraídos de nosso corpus.

1. e:: eles tiveram aí Olto filhos (AC 045 , L. 185);

2. fácil né?... se eles quisé::(r)... sei lá... (AC 053, L. 364);

3. e elas via aquela luzinha andá(r)... (AC 092, L. 122).

\footnotetext{
${ }^{14}$ Queremos esclarecer que para as variáveis material interveniente até quatro sílabas e mais de quatro sílabas, em nosso corpus, não tivemos tais variáveis com sujeitos pospostos, por esse motivo não as separamos em sujeitos pospostos ou antepostos.
} 
Quando o sujeito estava imediatamente posterior ao verbo, obtivemos um peso relativo baixo, indicando a não-aplicação da regra padrão de CV, 0.19 . Vejamos alguns exemplos:

1. na garagem... cabe dois ca::rros... (AC 021, L. 141);

2. chegou os médicos:: (AC 021, L. 141);

3. porque é as origens da minha família né? (AC 084, L. 231-232).

Decat (1983) postulou algumas hipóteses para tentar justificar a ausência de concordância em contextos em que o sujeito se encontra posposto ao verbo, a saber: desconhecimento da regra por parte do falante; variação linguística causada pela diferença fônica entre as formas verbais de terceira pessoa do singular e do plural; a perda da característica principal do sujeito, que seria a anteposição ao verbo; a responsabilidade que a posição do sujeito assume com relação à aplicação da regra da concordância verbal.

Parece-nos mais concreta a justificativa da ausência de concordância verbal que se baseia no fato dos SNs pospostos estarem deixando de desempenhar a função de sujeito porque estão perdendo, entre outras, a propriedade sintática de sujeito, já que o esperado seria o sujeito ocupar a posição no início da sentença. O sujeito posposto, portanto, seria sentido pelo falante como objeto e não como sujeito, pois ocupa, na sentença, o lugar reservado ao objeto direto e/ou indireto e, em razão disso, absorve, muitas vezes, as características desse objeto. 
$\mathrm{Na}$ maioria das vezes, como nos mostra o gráfico abaixo, sujeitos antepostos favorecem a aplicação da regra de CV.

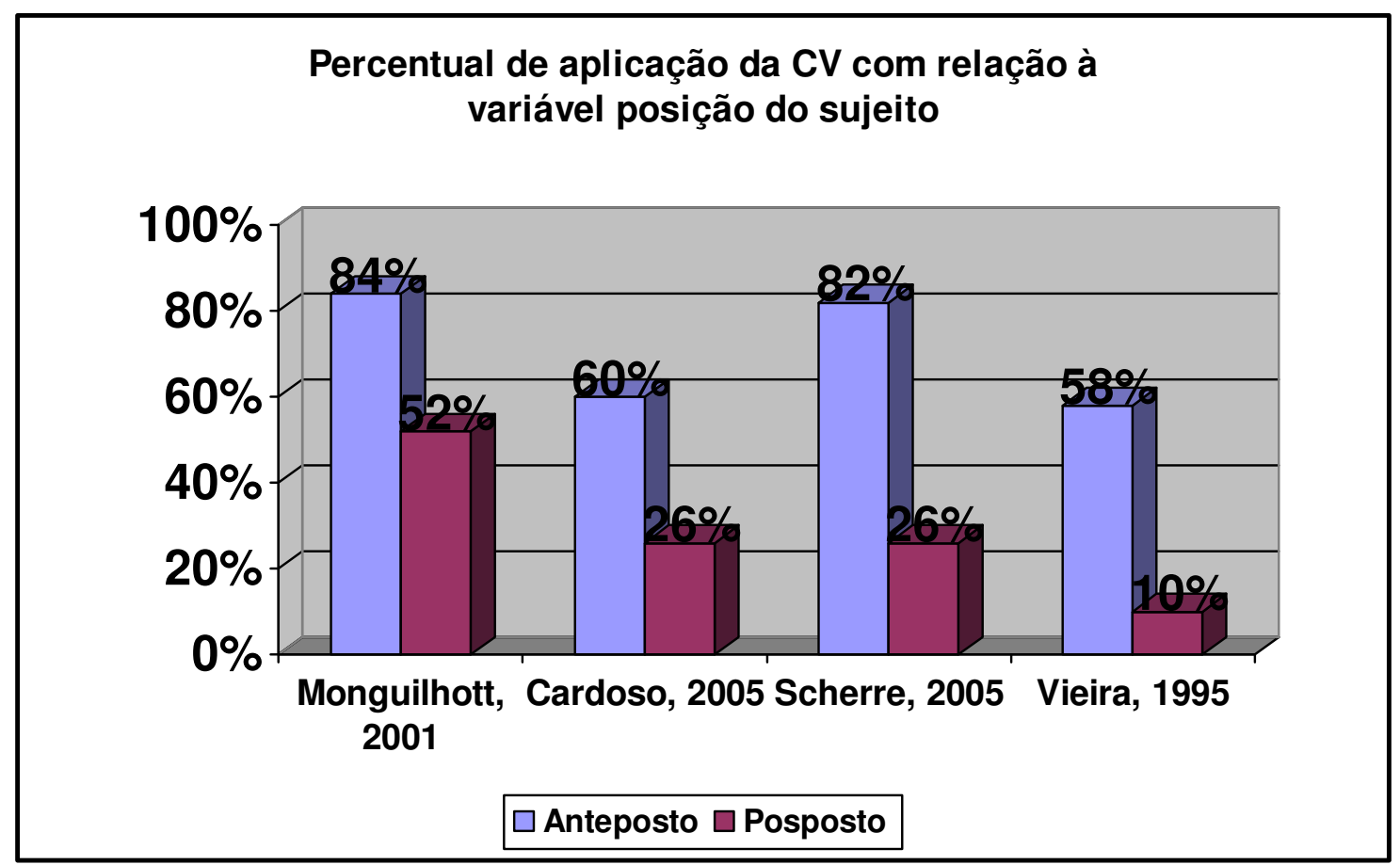

Gráfico 8: Aplicação de CV segundo a variável posição do sujeito: comparação entre os resultados de Monguilhott (2001), de Cardoso (2005), de Vieira (1995) e de Scherre (2005) ${ }^{15}$

Todos esses estudos indicam que o sujeito quando posposto ao verbo passa a ser encarado como objeto pelo falante, que não aplica a regra de concordância, já que não o considera como sujeito da sentença.

Em outro estudo, Scherre e Naro (1997) analisam a concordância verbo/sujeito, dentre outros fenômenos de concordância de número, focalizando as variáveis linguísticas saliência fônica e posição do sujeito e como variáveis extralinguísticas sexo,

\footnotetext{
${ }^{15}$ Em seu livro "Doa-se lindos filhotes de poodle", Scherre (2005) apresenta diversas reflexões acerca da concordância verbal de $3^{\text {a }}$ pessoa do plural. Neste seu trabalho, seu corpus principal são textos da mídia brasileira e portuguesa.
} 
idade e escolaridade, em dados de fala do PEUL, com 4632 construções de concordância verbal.

A amostra constitui-se de 64 informantes, sendo 32, masculino e 32, feminino, divididos de acordo com os seguintes anos de escolarização: 1 a 4; 5 a 8 e 9 a 11 anos.

Para o grupo de fatores posição, assim como nossos resultados e os resultados de outros linguistas expostos acima, os resultados de Scherre e Naro apontam para o fato de que, quando o sujeito está em uma posição à esquerda, existe maior probabilidade de favorecimento da ocorrência da regra de $\mathrm{CV}$, enquanto a posição à direita ao verbo a desfavorece.

Já a presença de até quatro sílabas entre sujeito e verbo se mostrou neutra, já que seu peso relativo (0.51) está próximo do 0.5 , considerado como ponto neutro, ou seja, não interfere na aplicação da regra de concordância verbal.

1. mas às vezes elas nem comentava com a minha mãe... (AC 092, L. 122-123);

2. aí os meus sobrinhos também estavam em Guaru::Ihos e foi super legal (AC 134, L. 16-17);

3. dois cachorrinho que me atrapalha mui::to (AC 091, L. 101-102).

A presença de mais de quatro sílabas entre o sujeito e o verbo ilustra a influência dessa variável na aplicação da regra em 0.93. Tal índice contraria a nossa expectativa, pois acreditávamos que o fator que mais influenciaria a presença da concordância verbal seria o sujeito imediatamente anterior.

Diante de tais resultados, julgamos que tal influência se relaciona ao fato de que quanto maior a distância entre sujeito e verbo, maior a necessidade de se marcar o 
plural no verbo, para que assim haja uma correlação entre sujeito e verbo justamente pelo fato de o sujeito se encontrar muito distante do verbo.

1. as mesas::... mais ou menos... prontas pra... serem separadas (AC 013, L. 180); 2. às vezes os sofrimentos e o/... os espinhos do casamento que fazem a família crescê(r)... (AC 091, L. 173-174);

3. os bandidos que eu não conhecia até cobriram a cabeça... (AC 092, L. 132-133);

4. meus parentes mais ou menos de sanque não vive aqui... né? ( $\mathrm{AC}$ 134, L. 25-26).

Abaixo, trago o resultado de Rocha Mattos (2003), que, em sua dissertação de mestrado, avaliou duas amostras de fala, uma de Fortaleza e outra do Rio de Janeiro, com o propósito de captar a sistematicidade da variação da concordância verbal. Foram analisados 793 dados coletados das amostras de Fortaleza e do Rio de Janeiro.

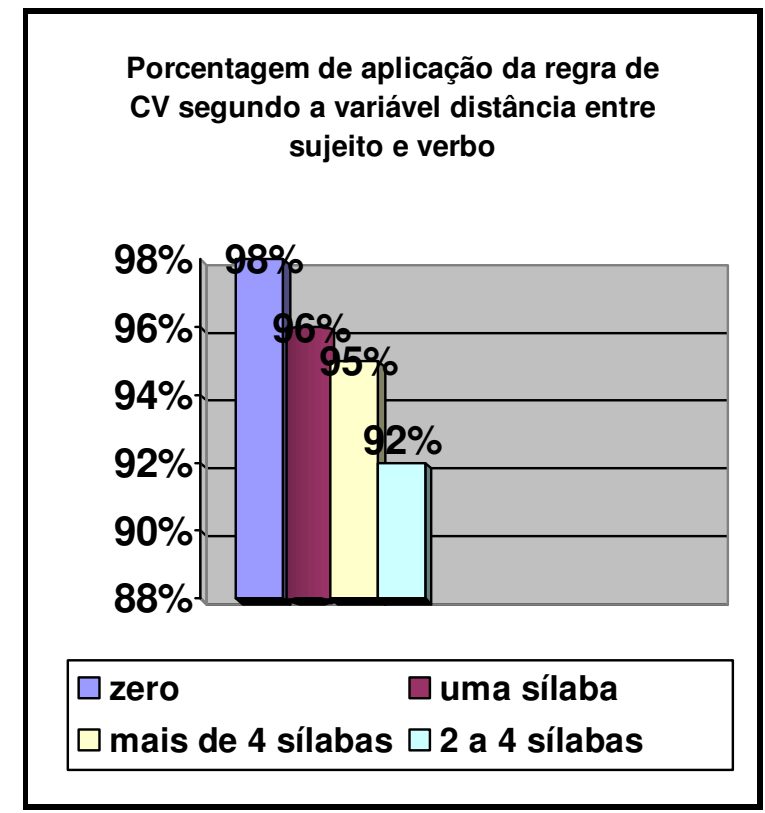

Gráfico 9: Percentual de aplicação da regra de CV nos dados de Rocha Mattos, 2003 
Os dados de Rocha Mattos (2003) demonstraram que, quando o sujeito está próximo do verbo, as chances de concordância aumentam em 98\%. E quando está distante entre duas a quatro sílabas favorece o uso do plural em $92 \%$. No entanto, a distância mais de quatro sílabas entre sujeito e verbo, como já salientava Rodrigues (1987), tende a se relacionar, na maioria das vezes, com a forma verbal marcada em número e pessoa, por estar distante do sujeito, o verbo precisa concordar com ele para que as ambiguidades sejam evitadas. Ao contrário do sujeito muito próximo ao verbo que, por estar imediatamente anterior a ele, pode favorecer a não aplicação da regra da concordância verbal, visto não alterar a compreensão do enunciado, já que não geraria nenhum tipo de ambiguidade.

Acreditamos que o cruzamento dos grupos de fatores nos permitirá verificar com maior precisão o efeito de um grupo sobre o outro no uso da regra de concordância verbal. Cruzaremos a variável paralelismo formal, primeira variável selecionada pelo programa Goldvarb-x em termos de relevância, com as demais variáveis, a fim de verificarmos como duas variantes se comportam juntas. Além desses cruzamentos, apresentamos também outros cruzamentos de fatores que consideramos significativos de acordo com a análise realizada. Sendo assim, abaixo trazemos o resultado do cruzamento entre as variáveis paralelismo formal e a variável distância e posição do sujeito. 


\section{ANÁLISE UNIDIMENSIONAL - APLICAÇÃO DA REGRA}

\begin{tabular}{|c|c|c|c|}
\hline $\begin{array}{c}\text { Paralelismo } \\
\text { formal }\end{array}$ & $\begin{array}{c}\text { Marca de plural } \\
\text { antecedente no 10 } \\
\text { e único elemento } \\
\text { do SN }\end{array}$ & $\begin{array}{c}\text { Marca de plural } \\
\text { antecedente em } \\
\text { e posição } \\
\text { do sujeito ou mais } \\
\text { elementos do } \\
\text { SN }\end{array}$ & $\begin{array}{c}\text { Marca zero } \\
\text { antecedente }\end{array}$ \\
\hline $\begin{array}{c}\text { Imediatamente } \\
\text { anterior }\end{array}$ & $291 / 327=89 \%$ & $53 / 55=96 \%$ & $7 / 25=28 \%$ \\
\hline $\begin{array}{c}\text { Imediatamente } \\
\text { posterior }\end{array}$ & $16 / 21=76 \%$ & $6 / 7=86 \%$ & $3 / 10=30 \%$ \\
\hline $\begin{array}{c}\text { Até 4 sílabas } \\
\text { Mais de 4 sílabas }\end{array}$ & $66 / 66=100 \%$ & $5 / 5=100 \%$ & $50 / 54=93 \%$ \\
\hline
\end{tabular}

Tabela 3: Cruzamento entre paralelismo formal oracional e distância e posição do sujeito

Observamos, com este cruzamento, que as marcas antecedentes de plural tendem a motivar a concordância verbal.

O índice de concordância aumenta à medida que aumenta a distância entre sujeito e verbo, quando há marca de plural no $1^{\circ}$ e único elemento do $S N$. Então temos para a distância imediatamente anterior entre sujeito e verbo, o percentual de aplicação da regra de $89 \%$. Para a distância imediatamente posterior temos um percentual de 76\% de aplicação da regra de CV. Quando há uma distância de até 4 sílabas, o percentual de aplicação da regra sobe para $94 \%$ e, nos casos em que a distância é superior a 4 sílabas, a aplicação da regra é de $100 \%$. 
Quando temos marca de plural antecedente em dois ou mais elementos do SN, o percentual para sujeitos que se encontram imediatamente anterior ao verbo é de $96 \%$. Tal fato evidencia que marcas levam a marcas, principalmente, quando já há uma sequência de marcas de plural. Isso nos leva a crer que quanto mais saliente for a relação verbo/sujeito, maior é a probabilidade de o verbo concordar com seu sujeito, quer este esteja no singular ou no plural.

Quando temos a combinação da variável marca zero no elemento antecedente ao verbo com a distância superior a 4 sílabas entre sujeito e verbo, o índice de aplicação da regra sobe para 93\%. Supomos que a porcentagem é maior, nesses casos, pelo fato de o sujeito estar distante do verbo, de modo que o "zero" antecedente ao verbo já não está tanto em evidência, como quando o sujeito com marca zero de plural imediatamente anterior, com $28 \%$ de aplicação da regra, ou posterior, com $30 \%$ de realização da concordância verbal. Fica claro compreendermos o alto índice de aplicação da regra de concordância para sujeitos que se encontram distantes do verbo mais de 4 sílabas, já que o percentual obtido com o cruzamento entre todas as variáveis do grupo de fator paralelismo formal com a variável mais de 4 sílabas de distância entre sujeito e verbo foi alto, analisando a tabela horizontalmente, superior à $90 \%$ de aplicação da regra.

Com o cruzamento destas duas variáveis, vemos que o percentual de aplicação da regra para sujeitos antepostos é superior a sujeitos pospostos. Isso porque como nossa língua apresenta a estrutura SVO, espera-se que os sujeitos ocupem a posição pré-verbal. Temos aqui mais uma evidência de que quanto mais saliente for a relação entre sujeito e verbo, maior será a probabilidade de haver uma correspondência entre a forma do sujeito, quer singular, quer plural, com o seu verbo. 


\subsection{FAIXA ETÁRIA}

A faixa etária 7-15 anos favoreceu a aplicação da regra em 95\%, fato que nos sugere o papel decisivo que a escola exerce na realização da regra da concordância verbal, uma vez que as faixas etárias 7-15 anos e 16-25 anos são as que apresentaram um maior percentual de aplicação da regra, $95 \%$ e 90\% respectivamente. Como nos mostra a tabela abaixo:

\begin{tabular}{|c|c|c|}
\hline FAIXA ETÁRIA & FREQUÊNCIA & PESO RELATIVO \\
\hline 7-15 ANOS & $128 / 134=95 \%$ & 0.86 \\
\hline 16-25 ANOS & $290 / 322=90 \%$ & 0.67 \\
\hline 26-35 ANOS & $275 / 324=85 \%$ & 0.40 \\
\hline 36-55 ANOS & $305 / 371=82 \%$ & 0.55 \\
\hline + DE 55 ANOS & $185 / 246=75 \%$ & 0.16 \\
\hline
\end{tabular}

TABELA 4: APLICAÇÃO DA REGRA SEGUNDO À FAIXA ETÁRIA

A não-aplicação da regra se encontra mais propícia na faixa etária mais de 55 anos, onde temos um percentual de $25 \%$ de falta de concordância. Podemos atribuir tal resultado ao fato de não estarem no mercado de trabalho.

Temos uma gradação do uso da regra de CV, visto que conforme a idade aumenta, aumenta também a ausência de concordância, como podemos observar no gráfico abaixo: 


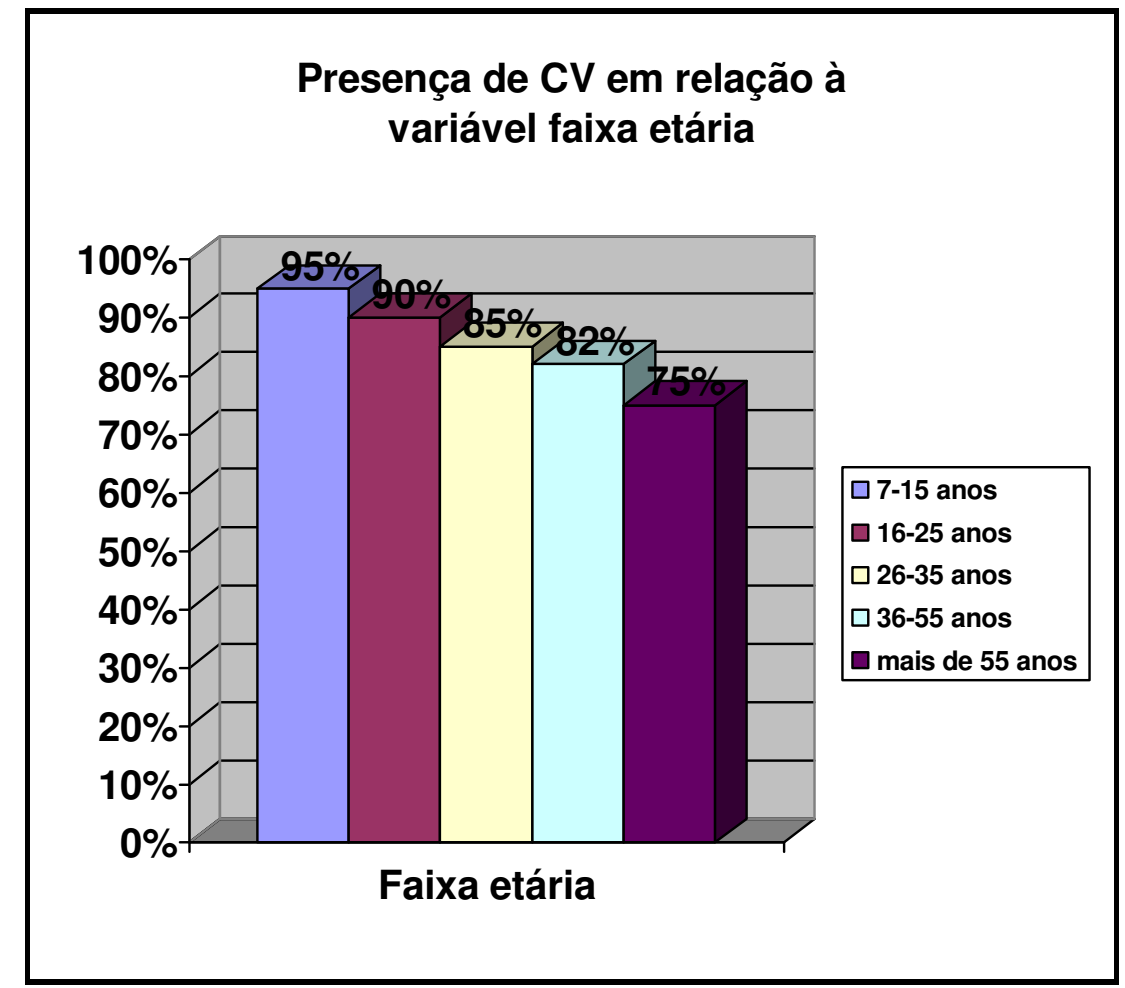

Gráfico 10: Aplicação da regra de CV com relação à faixa etária

Os resultados da pesquisa atestam que os informantes mais jovens apresentam maior probabilidade de concordarem sujeitos e verbos, ao passo que os mais velhos apresentam maior tendência à não-concordância.

Fator indicativo de que, na linguagem dos riopretenses, está havendo uma tendência a um sistema com concordância. Isso pode ser explicado pela influência que a escola exerce, já que entre os 7 e 25 anos o informante certamente frequenta a escola. E por ter consciência de que a ausência de concordância é estigmatizada, o uso da regra se faz mais presente. Ou até mesmo a necessidade de um emprego, de uma posição social faz com que tais informantes se policiem no momento em que falam. Ou ainda pelo fato de estas pessoas serem mais pressionadas pela idade profissionalmente produtiva e, dessa forma, usarem mais as formas prestigiadas. 
Os pesos relativos de tal grupo de fatores só confirmam os percentuais, ou seja, a faixa etária que se mostrou mais propícia ao uso da variante padrão é a de 7-15 anos, com 0.86. E a faixa etária menos propícia é a de + de 55 anos, com 0.16.

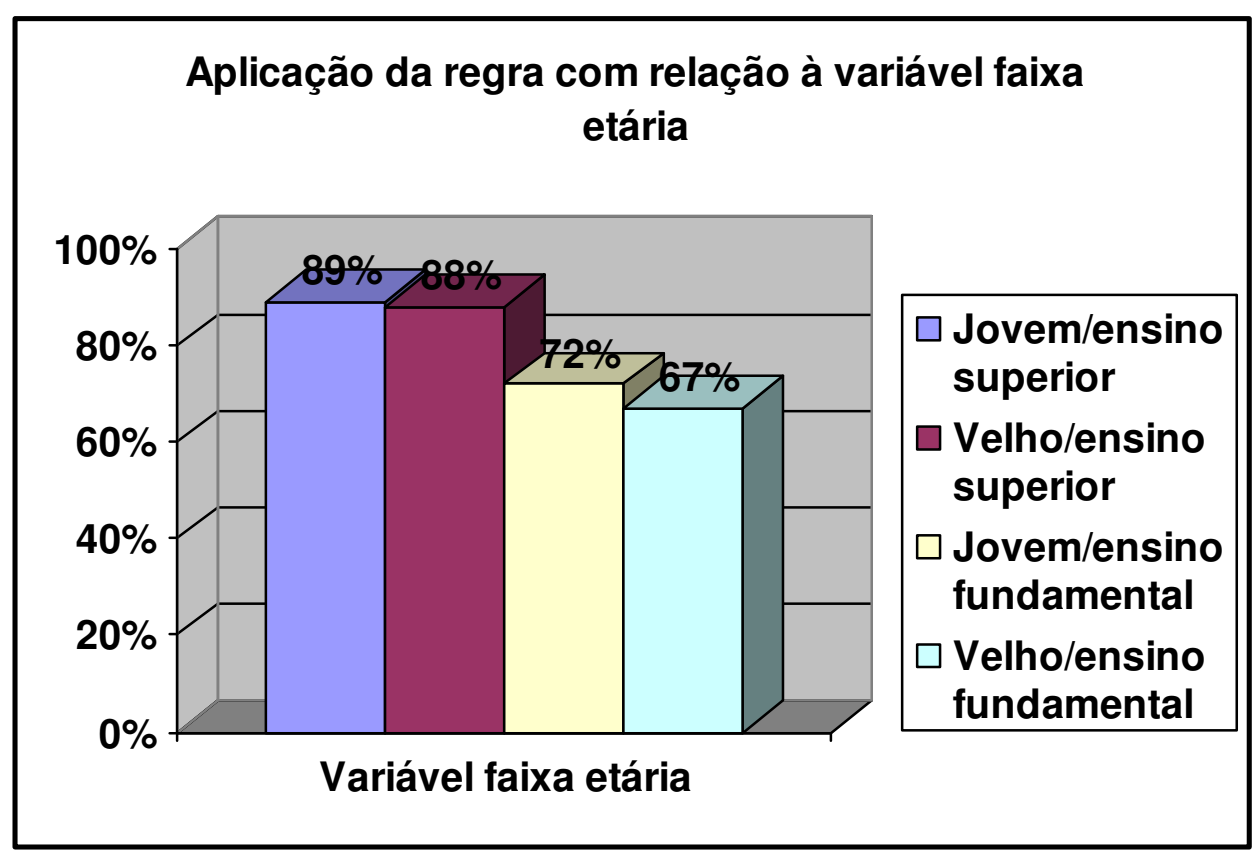

Gráfico 11: Aplicação de CV segundo a variável faixa etária (Monguilhott, 2009)

Monguilhott controlou conjuntamente os grupos de fatores idade e escolaridade. Monguilhott estudou 4 falantes com idade entre 15 e 36 anos com ensino fundamental; 4 falantes com idade entre 22 e 33 anos com ensino superior; 4 falantes com idade entre 48 e 74 anos com ensino fundamental e 4 falantes com idade entre 45 e 76 anos com ensino superior. Os resultados de Monguilhott (2009) também comprovam que há um uso da regra da CV maior em falantes jovens. Em sua tese, a linguista trabalha com o cruzamento entre as variáveis escolaridade e faixa etária, por isso temos: jovem/ensino superior; velho/ensino superior; jovem/ensino fundamental e velho/ensino fundamental. Tanto os jovens com ensino superior (89\%) quanto os jovens com ensino 
fundamental (72\%) aplicam mais a regra de CV do que os velhos com ensino superior (88\%) e com ensino fundamental (67\%). Isto nos revela uma tendência de uso da regra padrão pela camada mais jovem.

Além de a camada mais jovem ser a mais propícia para a realização da regra da concordância verbal, a escolaridade ensino superior também se mostrou atuante na aplicação da regra de concordância verbal, com $89 \%$ para os jovens e $88 \%$ para os velhos, percentuais muito próximos, o que nos leva a pensar que possivelmente a escolaridade exerça uma força atuante superior à faixa etária.

Gameiro (2005) estudou a concordância verbal na modalidade falada de indivíduos da região central do Estado de São Paulo. Foram utilizadas, como corpus, 25 entrevistas entre informante e documentador e 15 diálogos entre dois ou mais informantes, totalizando 40 gravações. Foram analisadas 1399 ocorrências de $3^{a}$ pessoa do plural. Ela observou que as faixas etárias mais jovens apresentam um percentual mais alto de presença de CV do que as faixas etárias mais velhas.

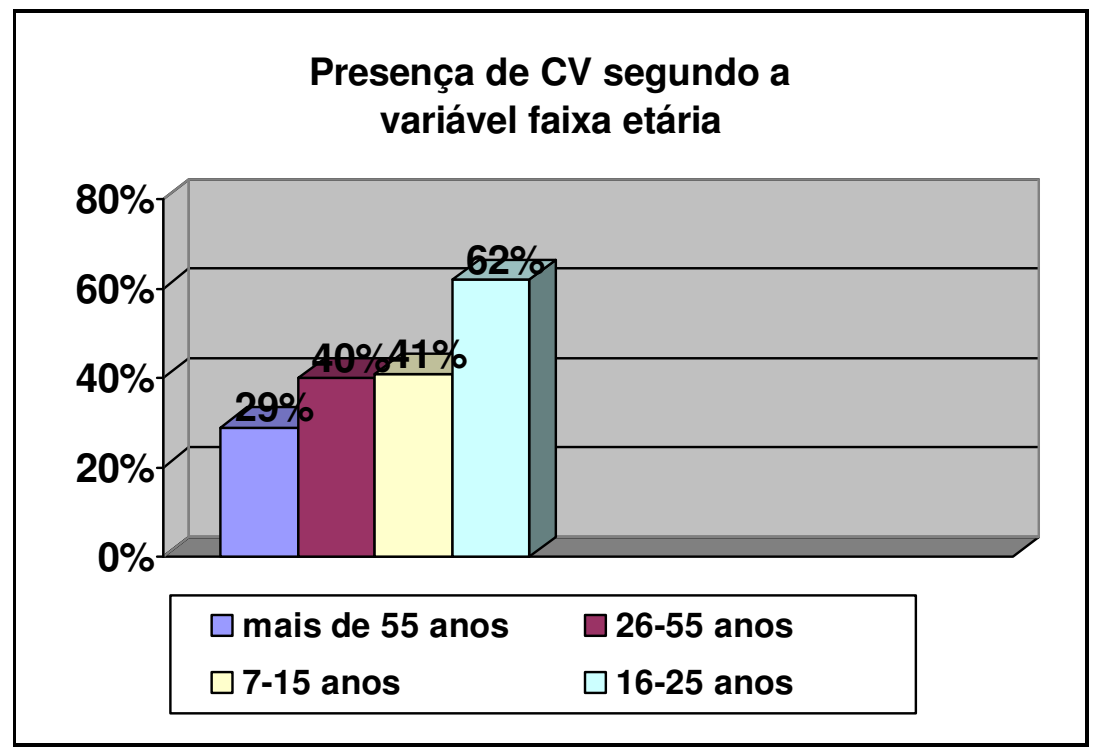

Gráfico 12: Aplicação de CV segundo a variável faixa etária (Gameiro, 2005) 
Apresentamos abaixo o cruzamento entre o paralelismo formal, variável mais relevante, segundo o programa computacional GOLDVARB-X, e a variável faixa etária, com o intuito de verificarmos como tais variáveis se comportam juntas.

\section{ANÁLISE UNIDIMENSIONAL - APLICAÇÃO DA REGRA}

\begin{tabular}{|c|c|c|c|}
\hline $\begin{array}{c}\text { Paralelismo } \\
\text { formal/ }\end{array}$ & $\begin{array}{c}\text { Marca de plural } \\
\text { antecedente no 10 } \\
\text { e único elemento } \\
\text { do SN }\end{array}$ & $\begin{array}{c}\text { Marca de plural } \\
\text { antecedente em } \\
\text { dois ou mais } \\
\text { elementos do } \\
\text { Faixa etária }\end{array}$ & $\begin{array}{c}\text { Marca zero } \\
\text { antecedente }\end{array}$ \\
\hline $7-15$ anos & $112 / 112=100 \%$ & $5 / 7=71 \%$ & $11 / 15=73 \%$ \\
\hline $16-25$ anos & $264 / 270=98 \%$ & $4 / 6=67 \%$ & $22 / 46=48 \%$ \\
\hline $26-35$ anos & $171 / 199=86 \%$ & $14 / 16=88 \%$ & $0 / 31=0 \%$ \\
\hline $36-55$ anos & $149 / 177=84 \%$ & $98 / 102=96 \%$ & $58 / 92=63 \%$ \\
\hline Mais de 55 anos & $216 / 245=88 \%$ & $29 / 29=100 \%$ & $30 / 50=60 \%$ \\
\hline Total & $912 / 1003=91 \%$ & $150 / 160=94 \%$ & $121 / 234=52 \%$ \\
\hline
\end{tabular}

Tabela 5: Cruzamento entre paralelismo formal oracional e faixa etária

Com o cruzamento das variáveis paralelismo formal e faixa etária, percebemos que as faixas etárias mais jovens, as que realizaram mais concordância, 7-15 anos e 16-25 anos, apresentam um alto percentual de concordância quando há marca de plural antecedente no 1ำ e único elemento do SN, 100\% e 98\% respectivamente.

As faixas etárias 26-35 anos, 36-55 anos e mais de 55 anos apresentaram um alto percentual de aplicação da regra de concordância nos casos em que havia marca de plural antecedente em dois ou mais elementos do SN, o índice foi de $88 \%$, $96 \%$ e $100 \%$ respectivamente. 
Os índices mais baixos de concordância pertencem às variáveis cruzadas 16-25 anos e marca zero antecedente com 48\% de aplicação da regra e 26-35 anos e marca zero antecedente com $0 \%$ de concordância, ou seja, não houve para este cruzamento, das 31 ocorrências, nenhum caso de concordância verbal.

Acreditamos que o cruzamento com a escolaridade poderá nos evidenciar se, nesta faixa etária (26-35 anos), os informantes são menos escolarizados e aí estaria uma possível explicação para o resultado obtido.

\subsection{VARIÁVEL ESCOLARIDADE}

Como era esperado, os resultados mostram que o ensino superior favorece a aplicação da regra de concordância verbal (93\% de frequência e 0,77 de peso relativo), como podemos verificar na tabela 6 abaixo:

\begin{tabular}{|c|c|c|}
\hline ESCOLARIDADE & FREQUÊNCIA & PESO RELATIVO \\
\hline ENS. FUNDAMENTAL I E II & $424 / 532=80 \%$ & 0.31 \\
\hline ENSINO MÉDIO & $380 / 456=83 \%$ & 0.44 \\
\hline ENSINO SUPERIOR & $379 / 409=93 \%$ & 0.77 \\
\hline TOTAL & \multicolumn{2}{|c|}{$1183 / 1397=85 \%$} \\
\hline
\end{tabular}

TABELA 6: APLICAÇÃO DA REGRA - VARIÁVEL ESCOLARIDADE

Os resultados apontam que os informantes mais escolarizados preservam mais as marcas de concordância verbal, enquanto os menos escolarizados tendem a empregar menos a regra de CV. Observamos que conforme a escolaridade aumenta mais se dá a aplicação da regra. 
Como Monguilhott (2009), cruzamos também o grupo de fator escolaridade com o grupo de fator faixa etária, com o intuito de averiguar se há uma relação entre faixa etária e escolaridade.

\section{ANÁLISE UNIDIMENSIONAL - APLICAÇÃO DA REGRA}

\begin{tabular}{|l|c|c|c|c|c|}
\hline $\begin{array}{l}\text { FAIXA ETÁRIA/ } \\
\text { ESCOLARIDADE }\end{array}$ & $\begin{array}{c}\mathbf{7 - 1 5} \\
\text { ANOS }\end{array}$ & $\begin{array}{c}\mathbf{1 6 - 2 5} \\
\text { ANOS }\end{array}$ & $\mathbf{2 6 - 3 5}$ ANOS & $\mathbf{3 6 - 5 5}$ ANOS & $\begin{array}{c}\text { + DE 55 } \\
\text { ANOS }\end{array}$ \\
\hline ENS. & $74 / 78=95 \%$ & ------ & $58 / 99=59 \%$ & $149 / 195=76 \%$ & $136 / 179=76 \%$ \\
\hline FUNDAMENTAL & & & & & \\
\hline ENSINO MÉDIO & $54 / 56=96 \%$ & $\begin{array}{c}177 / 205= \\
86 \%\end{array}$ & ------ & $156 / 176=89 \%$ & ---- \\
& & $86 \%$ & & ----- & $139 / 145=96 \%$ \\
\hline
\end{tabular}

Tabela 7: Cruzamento entre faixa etária e escolaridade

O cruzamento feito entre essas variáveis comprova que a faixa etária mais jovem aplica mais a regra de CV e que a variável escolaridade que apresenta mais marca de concordância verbal é o ensino médio e o ensino superior. Fato que ratifica a importância que a escolaridade exerce sobre a aplicação da regra de CV.

Tais dados indicam que a rápida passagem pela escola não garante o aprendizado das regras de concordância verbal, é necessário um contato maior para que o uso da variedade padrão se instaure na fala de falantes menos escolarizados, uma vez que o ensino fundamental apresentou os menores índices de aplicação da regra, com exceção da faixa etária de 7-15 anos, com 95\% de aplicação da regra. 
A faixa etária entre 7 a 15 anos apresentou um alto índice de aplicação da regra: 95\% para o ensino fundamental e $96 \%$ para o ensino médio. Supomos que tal índice tenha sido alto pelo fato de o informante estar em contato com as regras gramaticais, devido à influência que a escola exerce na vida do aluno.

Para as faixas etárias 26-35 anos, 36-55 anos e mais de 55 anos, o percentual de aplicação da regra é mais baixo no ensino fundamental, supomos que o fato de eles estarem há certo tempo distantes da escola, além de terem tido uma passagem curta por ela, gera a ausência de concordância verbal.

Pelo cruzamento, observamos que os informantes de 26 a 35 anos cancelam a concordância em maiores proporções do que as demais faixas etárias. Há apenas 59\% de aplicação da regra para informantes nessa faixa etária com ensino fundamental e $86 \%$ com ensino superior. Para tais níveis de escolaridade foram os menores percentuais encontrados.

Os percentuais aumentam à medida que a escolaridade aumenta. $\mathrm{O}$ ensino superior atinge um percentual de $97 \%$ de aplicação da regra de CV na faixa etária 1625 anos e 96\% na faixa etária mais de 55 anos.

Vários estudos realizados têm comprovado que a escolaridade dos informantes exerce forte influencia no uso de traços linguísticos pertencentes ao português padrão, isto é, há correlação entre o uso de formas da norma padrão e o grau de escolaridade dos informantes. Isso porque ao longo dos anos a escola tenta transmitir aos alunos a variedade padrão ou a norma de prestígio social.

Como apresentado na seção 5.3, ficou em aberto o porquê da fala de informantes na faixa etária de 26-35 anos não concordarem em nenhum dos 31 casos onde havia marca zero antecedente. E de fato, com o cruzamento entre os grupos de 
fatores faixa etária e escolaridade observamos que é, realmente, mais baixo o percentual de concordância em tal faixa etária. A aplicação da regra para os informantes com ensino fundamental foi de $59 \%$ e a aplicação da regra de concordância verbal para o ensino superior foi de $86 \%$. Não podemos deixar de mencionar o fato de não termos tido nenhum informante entre $26-35$ anos no ensino médio. Supomos que o alto índice de realização da regra de CV para o ensino superior, $86 \%$, acontece pelo fato de que muitos informantes, nessa faixa etária, ainda estão cursando o ensino superior ou o deixaram há pouco tempo. Em contrapartida, aqueles que cursaram somente o ensino fundamental já estão há bastante tempo longe das escolas.

Apresentamos abaixo outros gráficos de outras linguistas (Monguilhott, 2001 e Rocha Mattos, 2003) que comprovam que a variável escolaridade realmente influencia a presença de CV.

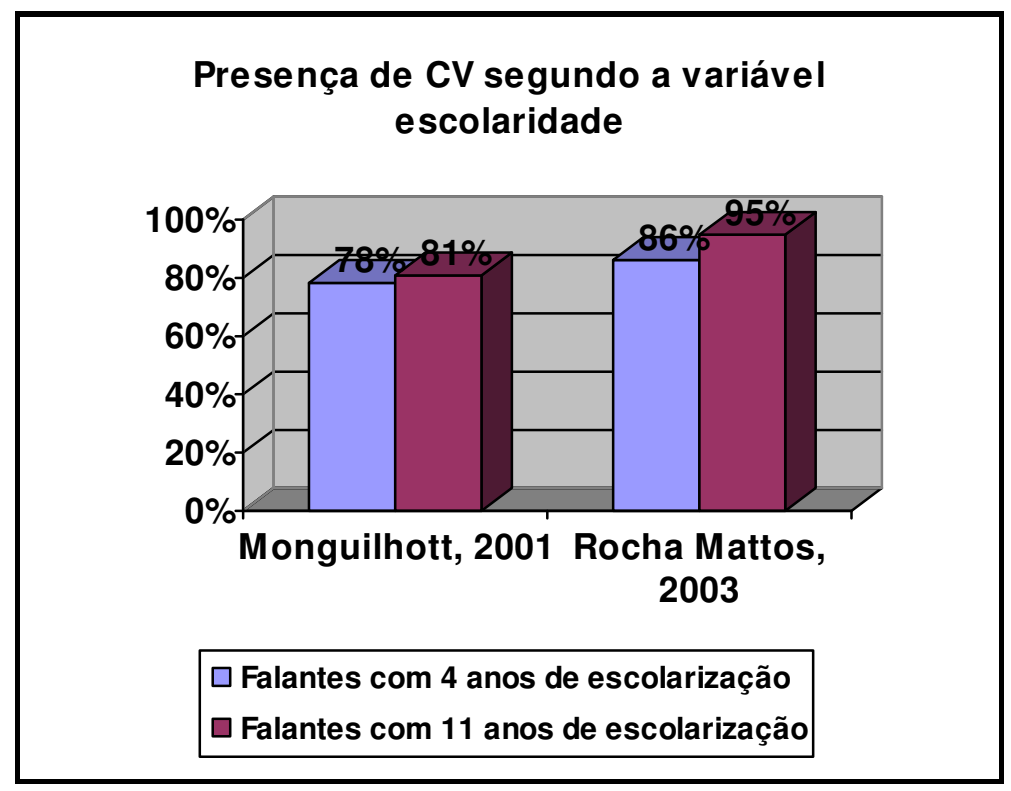

Gráfico 13: Aplicação de CV segundo a variável escolaridade: contraste entre os resultados de Monguilhott, 2001 e de Rocha Mattos, 2003 
Os resultados confirmam, ainda, que os informantes mais escolarizados, independentemente da idade, preservam as marcas de concordância verbal, correspondendo, desta forma, aos resultados de outros estudos, como os de Monguilhott (2001) e Rocha Mattos (2003) que controlaram a escolaridade em amostras do PB. Vale ressaltar que a diferença percentual entre os diferentes níveis de escolarização não é grande como, por exemplo, em Monguilhott (2001), temos 78\% de manutenção da regra de CV para falantes com quatro anos de escolarização e $81 \%$ para falantes com 11 anos de escolarização e, em Rocha Mattos (2003), temos 86\% e 95\%, respectivamente. Assim também acontece aos nossos resultados, já que temos $80 \%$ de manutenção da regra de concordância verbal para ensino fundamental I e II, 83\% para ensino médio e 93\% para ensino superior. Os altos índices de aplicação da regra, mesmo quando se tem um grau de escolaridade mais baixo, nos parece mais uma evidência de que a escolaridade apresenta-se como um fator de peso nas diversas amostras, independentemente da região analisada.

\subsection{SALIÊNCIA FÔNICA}

Este é um dos grupos de fatores mais analisados por estudiosos acerca da concordância verbal, o que mostra a sua relevância e influência na aplicação ou inibição da regra.

Nossos dados comprovam a tendência geral, segundo a qual quanto mais saliente for a diferença fônica entre o singular e o plural dos verbos, maior a probabilidade de o verbo apresentar marcas formais de plural para concordar com seu respectivo sujeito. 


\begin{tabular}{|c|c|c|}
\hline SALIÉNCIA FÔNICA & FREQUÊNCIA & PESO RELATIVO \\
\hline FALAVA/FALAVAM & $266 / 331=80 \%$ & 0.41 \\
\hline FAZ/FAZEM & $37 / 53=70 \%$ & 0.24 \\
\hline ESTÁ/ESTÃO & $57 / 61=93 \%$ & 0.64 \\
\hline FALOU/FALARAM & $181 / 194=93 \%$ & 0.65 \\
\hline TROUXE/TROUXERAM & $55 / 59=93 \%$ & 0.81 \\
\hline É/SÃO & $70 / 78=90 \%$ & 0.75 \\
\hline
\end{tabular}

TABELA 8: APLICAÇÃO DA REGRA - SALIÊNCIA FÔNICA

Do que se observa, foi confirmada a hipótese de que o nível de saliência fônica na oposição singular/plural dos verbos atua no condicionamento da concordância verbal.

As formas verbais que mais deixam de concordar, isso é, que apresentam o maior percentual de ausência de concordância verbal, 30\% (37/ 53), são as formas verbais que se diferenciam em geral pela adição de uma vogal ou ditongo nasalizados à forma do singular, como em faz/fazem, uma vez que a oposição singular/plural também é inacentuada, o que favorece a ausência de concordância verbal. O peso relativo, 0.24, vem confirmar que tais formas verbais contribuem para o desfavorecimento do uso da regra padrão.

Outras formas verbais que também deixam de concordar são as formas que se diferenciam pela nasalização da vogal átona final, como em come/ comem, que apresentam o segundo maior percentual de ausência de concordância verbal, 20\% (266/331). Nesses verbos, a diferença entre o plural e o singular não é muito perceptível ou saliente e tal característica se configura como forte fator condicionante para a não-aplicação da regra de concordância verbal. 
A classe dos pretéritos perfeitos regulares (falou/falaram; aprendeu/ aprenderam; dormiu/dormiram) e a classe dos verbos cujo elemento vocálico tônico oral no singular contrasta com ditongo tônico nasal no plural (estál estão; vai/vão; dá/dão) apresentaram como peso relativo 0,65 e 0,64, respectivamente. Notamos que o uso da regra padrão foi aumentando de acordo com a oposição fônica entre singular/plural, haja vista que quanto mais perceptível era a oposição entre singular/plural mais concordância o informante realizou.

O verbo ser (é/são), caso único, no presente do indicativo, apresentou grande predomínio de aplicação da regra de concordância verbal, já que em $90 \%$ dos casos com o verbo ser houve concordância. Isso nos leva a crer que o verbo ser condiciona a aplicação da regra de CV devido à sua saliente oposição entre singular/plural e também pelo fato de ser de grande uso na língua, talvez até mesmo o mais usado, o que cristaliza a diferença entre sua forma do singular e do plural (é/são).

Verbos no pretérito perfeito irregular, com variação do grau de abertura da vogal tônica, em ambas as formas do singular e do plural como em trouxe/ trouxeram; fez/fizeram apresentaram o maior peso relativo $0,81(93 \%-55 / 59)$, indicando um favorecimento à presença da concordância verbal. A alta saliência de tais verbos inibe o uso da variante não-padrão.

Naro (1981), em seu artigo "The social and structural dimensions of a syntactic change", discutiu a influência exercida pela saliência fônica na realização da concordância verbal. O trabalho de Naro (1981) retoma os mesmos dados do Projeto Competências Básicas do Português e reanalisa a variação da regra de concordância verbal no português. Naro argumenta que, na perda da concordância verbal, a força linguística atuante é a de uma regra de desnasalização das vogais finais que atua sobre 
as formas verbais do tipo come/comem. Tal perda de oposição fônica entre singular/plural causa uma confusão na estrutura de superfície da língua. Para Naro (1981), a difusão do sistema sem concordância se dá de acordo com o princípio da saliência, que se estende mais fortemente em contextos onde a mudança é menos perceptível e consiste no princípio de que as formas mais salientes são mais favoráveis a presença da marca de concordância, enquanto as menos salientes são desfavoráveis.

Abaixo apresento os resultados de Cardoso (2005), de Vieira (1995) e de Naro (1981), com relação à saliência fônica.

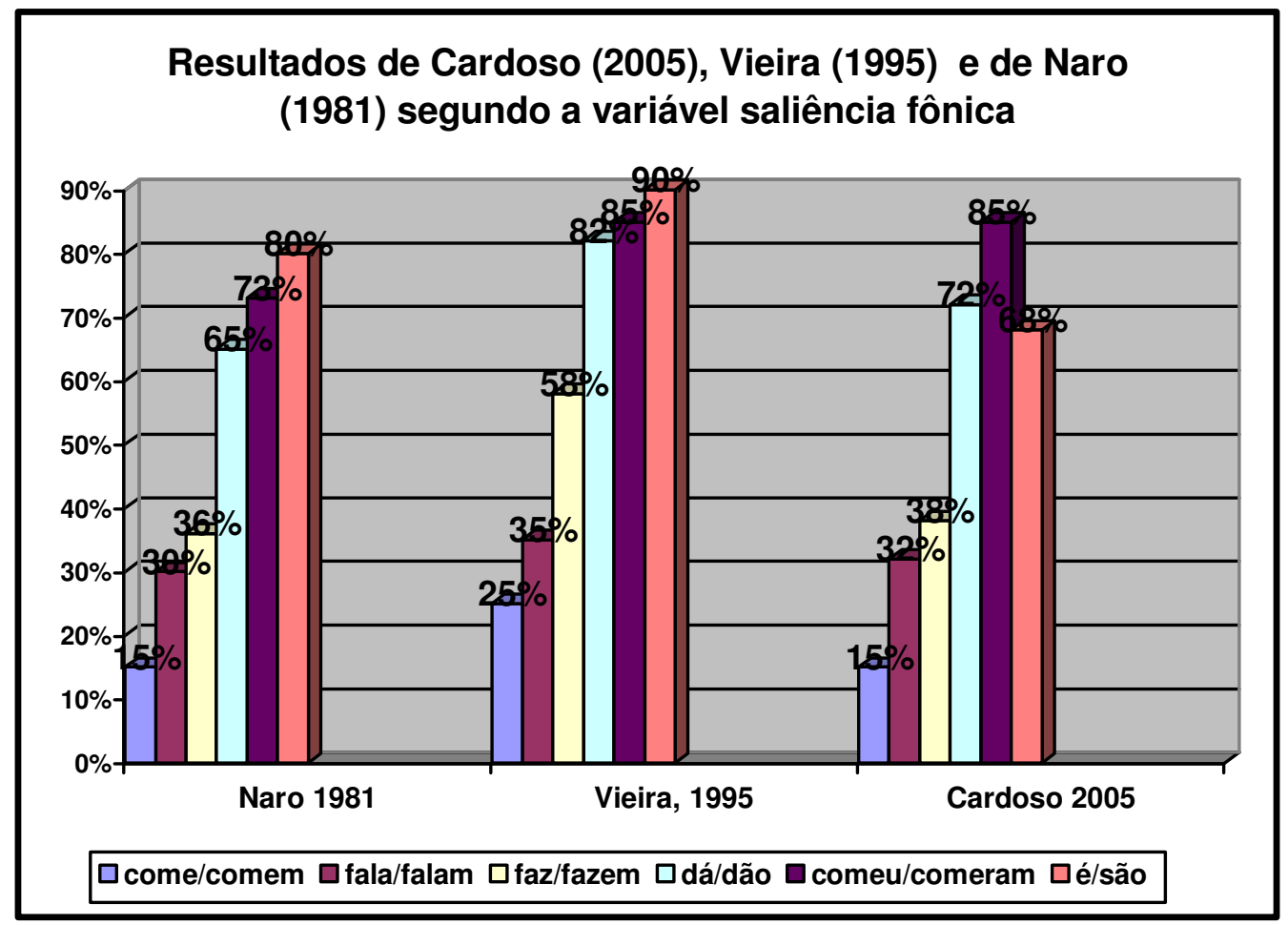

Gráfico 14: Contraste entre os resultados encontrados por Cardoso (2005), Vieira (1995) e Naro (1981) segundo a variável saliência fônica - aplicação da regra de CV 
Observamos, nos resultados de Vieira (1995), que o nível mais baixo de saliência fônica - come/comem - favorece o cancelamento da marca de número de modo acentuado (somente $25 \%$ de aplicação da regra), seguido do segundo nível de saliência fônica - fala/falam - (35\% de aplicação da regra) que, por sua vez, vem seguido do terceiro nível - faz/fazem; quer/querem (58\% de aplicação da regra). A próxima classe dá/dão e vai/vão - apresenta maior índice de concordância (82\%). As formas verbais comeu/comeram e é/são são as que mais favoreceram o uso da concordância verbal, em $85 \%$ e $90 \%$, respectivamente. Cardoso (2005) encontra resultados diferentes para a forma verbal é/são com, apenas, 68\% de aplicação da regra de CV. Essa forma verbal apresentou, nos outros dois estudos, um percentual maior de aplicação da regra; padrão que não ocorreu em Cardoso (2005). Supomos que tal padrão não tenha se cumprido em Cardoso, pelo fato de sua pesquisa estar centralizada na fala de uma mesma informante. Talvez se houvesse um número maior de informantes o resultado seria outro.

Diante do exposto, podemos observar que as formas verbais em que a oposição singular/plural ocorre apenas nas terminações átonas (fala/falam; come/comem; faz/fazem) formam uma classe que favoreceu a não-aplicação da regra.

O restante das formas verbais (estálestão; foi/foram; é/são; falou/ falaram) formam o grupo em que a oposição singular/plural é mais perceptível, mais saliente, fazendo com que a correlação entre o sujeito de $3^{\text {a }}$ pessoa do plural e o verbo seja mais perceptível. Além de ser, é claro, mais estigmatizado socialmente dizer "eles é" do que "eles ama”.

Do que se expôs, foi confirmado o princípio de que a tendência à concordância aumenta à medida que se intensifica a diferença material fônica entre as formas 
singular e plural dos verbos.

Abaixo trazemos o cruzamento entre as variáveis paralelismo formal e saliência fônica.

\section{ANÁLISE UNIDIMENSIONAL - APLICAÇÃO DA REGRA}

\begin{tabular}{|c|c|c|c|}
\hline $\begin{array}{c}\text { Paralelismo } \\
\text { formal/ }\end{array}$ & $\begin{array}{c}\text { Marca de plural } \\
\text { antecedente no 1o } \\
\text { e único elemento } \\
\text { do SN }\end{array}$ & $\begin{array}{c}\text { Marca de plural } \\
\text { antecedente em } \\
\text { dois ou mais } \\
\text { elementos do } \\
\text { fônica }\end{array}$ & $\begin{array}{c}\text { Marca zero } \\
\text { antecedente }\end{array}$ \\
\hline Falava/falavam & $206 / 240=86 \%$ & $33 / 35=94 \%$ & $27 / 56=48 \%$ \\
\hline Faz/fazem & $35 / 41=85 \%$ & $0 / 1=0 \%$ & $2 / 11=18 \%$ \\
\hline Está/estão & $45 / 47=96 \%$ & $8 / 8=100 \%$ & $4 / 6=67 \%$ \\
\hline Falou/falaram & $120 / 125=96 \%$ & $24 / 26=92 \%$ & $37 / 43=86 \%$ \\
\hline Trouxe/trouxeram & $36 / 36=100 \%$ & $11 / 11=100 \%$ & $8 / 12=67 \%$ \\
\hline É/são & $59 / 59=100 \%$ & $3 / 3=100 \%$ & $8 / 16=50 \%$ \\
\hline
\end{tabular}

Tabela 9: Cruzamento entre paralelismo formal oracional e saliência fônica

Com esse cruzamento, observamos que, quando temos ausência de marca de plural no elemento antecedente ao verbo, o índice de frequência de concordância diminui sensivelmente em todas as classes verbais. Os percentuais gerados pelo Goldvarb-x nos mostram que as marcas antecedentes ao verbo atuam de maneira significativa no uso do plural. Porém a ausência de marca de plural no termo antecedente ao verbo inibe, em todas as classes verbais da saliência fônica, o uso da concordância. 
Com o cruzamento entre esses dois grupos de fatores, percebemos que a classe dos verbos de oposição inacentuada do tipo falava/falavam que comumente apresenta um percentual baixo de realização da regra de concordância verbal, muda esta frequência conforme as marcas de plural no SN que o antecede. Quando há marca de plural no $1^{\circ}$ e único elemento do SN, a porcentagem de aplicação da regra é de $86 \%$.

Quando há marca de plural antecedente em dois ou mais elementos do $\mathrm{SN}$, a porcentagem de aplicação da regra é de $94 \%$, enquanto que quando há marca zero antecedente ao verbo é de $48 \%$ de aplicação da regra de concordância. Tais resultados evidenciam que o princípio do paralelismo é fortemente atuante no uso da regra de concordância verbal e que pode influenciar, até mesmo, a força da saliência fônica verbal, que também é outro fator atuante na aplicação da regra de concordância verbal.

Com os verbos cuja oposição entre singular e plural se dá numa vogal final átona, possivelmente, nasalada como faz/fazem temos que a marca de plural antecedente ao verbo propiciou a realização da concordância verbal em 85\%, enquanto que marca zero antecedente propiciou a realização da concordância em apenas $18 \%$.

Com as demais classes verbais mais salientes temos também altos índices de aplicação da regra quando há marcas antecedentes ao verbo. Já quando há marca zero, o percentual de concordância diminui. Diante disso podemos inferir que independentemente da saliência fônica do verbo, quando há zero no antecedente, a frequência da concordância diminui.

Analisando a tabela horizontalmente, todas as outras classes verbais seguem esta mesma tendência de concordar conforme as marcas de plural no SN antecedente. Por outro lado, considerando a tabela verticalmente, podemos observar que, mesmo havendo marca formal de plural em elementos antecedentes ao verbo, há um 
porcentual maior de ausência de CV com verbos de baixa saliência, como falava/falaram seja decisivo para aplicação da regra de concordância verbal, pois em todos os tipos verbais cujos SNs sujeitos não possuíam marca de plural no $2^{\circ}$ elemento, houve ausência de concordância verbal. Sendo assim, podemos afirmar que a ausência de marcas no SN favorece fortemente a ausência de concordância verbal. De modo que os dados por nós analisados, bem como os dos pesquisadores consultados, levamnos a acreditar que o paralelismo formal é mais significativo que o grupo de fatores saliência fônica.

\subsection{VARIÁVEL ESTRUTURA DO SUJEITO}

Esta variável comprova os resultados da variável paralelismo formal, uma vez que a estrutura núcleo do sujeito no plural com ou sem determinante no plural apresentou como percentual de aplicação da regra $85 \%$ e como peso relativo de 0.65 , índices que comprovam que marcas no sujeito levam a marcas no verbo.

1. tudo essas coisas obriGAram ele teve que ficá(r) uma semana (AC 109, L. 195196);

2. essas pessoas vivem fugindo da igre::já (AC 092, L. 240);

3. branco pálido... os lábios dele tavam branco... (AC 109, L. 113).

Pronomes demonstrativos e pronomes pessoais apresentaram como peso relativo 0.57 e 0.46 , respectivamente, peso relativo que os deixa em uma posição de neutralidade, isto é, não favorecem nem desfavorecem a aplicação da regra. 
1. né?... aquelas não ia dar certo... (AC 133, L. 129);

2. então... essas só queriam aproveitar a vida... (AC 150, L. 114-115).

3. não que eles vão sê(r) fácil (AC 092, L. 227);

4. pra eles... consegui(r)... aí:: é porque isso e aquilo (AC 110, L. 452);

Já a estrutura numeral e núcleo do sujeito no singular com apenas o determinante no plural desfavorece a aplicação da regra, com 0.16 e 0.19 de peso relativo, respectivamente. Outro dado que também comprova o postulado do paralelismo formal, zeros levam a zeros, isto é, elemento anterior ao verbo no singular leva o verbo a ficar no singular também.

A presença de um determinante numeral desfavorece a marca de plural do termo determinado. Isso nos faz refletir sobre o que estaria, de fato, sendo responsável por esse índice de não-concordância 0.16 , conforme nos mostra a tabela 10, para os casos de numerais. O traço semântico de pluralidade no numeral não deveria resultar em marca no sintagma verbal? Pelo visto, não. Talvez a explicação para esse resultado consista no fato de que o paralelismo leva à repetição de formas e não de idéias, como salientou Scherre (1998). De tal modo que o traço semântico de pluralidade, por si só, não nos parece ser suficiente para favorecer a concordância. Mas como não temos em nosso corpus um número grande de ocorrências, apenas 13, acreditamos que tais hipóteses só se poderão confirmar por meio de um estudo específico que considere os traços semânticos de vocábulos que denotam quantidade.

1. agora os dois pede isso e aquilo... (AC 043, L. 163); 
2. e as duas de trás pegô(u) nas minhas costa aí ele me empurrô(u)... bati a testa no tanque (AC 044, L. 73-74).

\begin{tabular}{|c|c|c|}
\hline ESTRUTURA DO SUJEITO & FREQUENCIA & PESO RELATIVO \\
\hline $\begin{array}{c}\text { PRONOME PESSOAL } \\
\text { DETERMINANTE NO } \\
\text { PLURAL }\end{array}$ & $300 / 335=90 \%$ & 0.46 \\
\hline $\begin{array}{c}\text { SOMENTE NOME NO } \\
\text { PLURAL }\end{array}$ & $184 / 216=85 \%$ & 0.19 \\
\hline $\begin{array}{c}\text { PRONOME } \\
\text { DEMONSTRATIVO }\end{array}$ & $17 / 20=85 \%$ & 0.65 \\
\hline NUMERAL & $9 / 13=69 \%$ & 0.16 \\
\hline
\end{tabular}

TABELA 10: APLICAÇÃO DA REGRA - ESTRUTURA DO SUJEITO

Apresentamos abaixo a tabela do cruzamento entre as variáveis paralelismo formal e estrutura do sujeito. 


\section{ANÁLISE UNIDIMENSIONAL - APLICAÇÃO DA REGRA}

\begin{tabular}{|c|c|c|c|}
\hline $\begin{array}{c}\text { Paralelismo } \\
\text { formal/ }\end{array}$ & $\begin{array}{c}\text { Marca de plural } \\
\text { antecedente no 10 } \\
\text { e único elemento } \\
\text { do sujeito }\end{array}$ & $\begin{array}{c}\text { Marca de plural } \\
\text { antecedente em } \\
\text { dois ou mais } \\
\text { elementos do } \\
\text { SN }\end{array}$ & $\begin{array}{c}\text { Marca zero } \\
\text { antecedente }\end{array}$ \\
\hline $\begin{array}{c}\text { Pronome pessoal } \\
\text { Somente } \\
\text { determinante no } \\
\text { plural }\end{array}$ & $238 / 267=89 \%$ & ------ & $3 / 7=43 \%$ \\
\hline $\begin{array}{c}\text { Somente nome } \\
\text { no plural }\end{array}$ & $154 / 167=92 \%$ & $3 / 3=100 \%$ & $2 / 32=6 \%$ \\
\hline $\begin{array}{c}\text { Pronome } \\
\text { demonstrativo }\end{array}$ & $14 / 16=88 \%$ & $59 / 61=97 \%$ & $3 / 4=75 \%$ \\
\hline Numeral & $1 / 1=100 \%$ & $8 / 11=73 \%$ & $0 / 1=0 \%$ \\
\hline
\end{tabular}

Tabela 11: Cruzamento entre paralelismo formal oracional e estrutura do sujeito

Com o cruzamento entre as variáveis paralelismo formal e estrutura do sujeito, observamos que o pronome pessoal eles/elas está diretamente ligado ao paralelismo, mais, diretamente, com a classe dos SNs que recebe marca de plural apenas no $1^{0} \mathrm{e}$ único elemento, já que apresentou $89 \%$ de porcentagem de aplicação da regra.

Pelo fato de não termos muitas ocorrências com numerais, não nos parece uma amostragem significativa, talvez se houvesse um número maior de ocorrências, poderíamos ter resultados diferentes. Mas de todo modo estrutura como: "e as duas de trás pegô(u) nas minhas costa aí ele me empurrô(u)... bati a testa no tanque" (AC044, L. 73-74), foi a que menos favoreceu a presença da concordância verbal, apresentando um percentual de $73 \%$. 
Há uma sobreposição das variáveis núcleo do sujeito no singular com apenas o determinante no plural com marca zero antecedente ao verbo. Tal cruzamento mostrou que das 32 ocorrências somente em 02 houve a presença de plural. Há $94 \%$ de possibilidade de, nestes casos, ocorrer a ausência da concordância verbal.

A variável núcleo do sujeito no plural com ou sem determinante no plural favoreceu a concordância verbal, quando havia marca no $1^{\circ}$ e único elemento antecedente ao verbo, em $92 \%$.

Do cruzamento entre $S N$ composto por dois ou mais elementos com marca de plural antecedentes ao verbo e núcleo do sujeito no plural com ou sem determinante no plural obtivemos um percentual de $100 \%$ de aplicação da regra.

O pronome demonstrativo se comportou de maneira semelhante à demais variantes, uma vez que marcas antecedentes favoreceram a aplicação da regra, enquanto que marca zero antecedente desfavoreceu o uso da concordância verbal.

De um modo geral, a tabela 11 nos evidencia que a concordância é controlada pelo princípio do paralelismo formal e não pela estrutura do sujeito.

A seguir apresento os grupos de fatores que não foram selecionados pelo programa estatístico GOLDVARB-X, porém que se revelaram importantes em outras pesquisas variacionistas.

\subsection{VARIÁVEL SEXO}

Embora esta variável não tenha sido selecionada pelo programa estatístico GOLDVARB-X, faremos uma discussão a respeito dela, porque há trabalhos, como o de Gameiro (2005), que atestam sua importância. 
Estudos sociolinguísticos já demonstraram que as mulheres, em geral, preocupam-se mais com o modo como falam e por isso são as que mais utilizam a regra padrão, de prestígio. Além disso, as mulheres tendem a ser mais conservadoras do que os homens.

Tal tendência também é confirmada em nossa amostra, visto que as mulheres apresentam percentual ligeiramente maior de presença de concordância verbal, 87\% $(0,56)$ contra $83 \%(0,46)$ de aplicação da regra por parte dos homens.

\begin{tabular}{|c|c|c|}
\hline GENNERO & FREQUÊNCIA & PESO RELATIVO \\
\hline FEMININO & $87 \%$ & 0.56 \\
\hline MASCULINO & $83 \%$ & 0.46 \\
\hline
\end{tabular}

Tabela 12: Aplicação da regra de CV para a variável sexo

No entanto, vemos que tal diferença tanto em termos de porcentagens como em termos de pesos relativos é bastante pequena. Isso evidencia que tanto os homens quanto as mulheres usam, de modo geral, a regra padrão, de prestígio.

Abaixo trazemos os nossos resultados e os de Monguilhott (2009), que evidenciam a tendência de uso da regra de CV por parte das mulheres.

\begin{tabular}{|c|c|c|}
\hline & FEMININO & MASCULINO \\
\hline NOSSOS RESULTADOS & $87 \%$ & $83 \%$ \\
\hline MONGUILHOTT (2009) & $85 \%$ & $72 \%$ \\
\hline
\end{tabular}

Tabela 13: Contraste entre os resultados encontrados por nós e por Monguilhott (2009) - aplicação de regra da CV para a variável sexo

Trazemos abaixo o cruzamento entre as variáveis paralelismo formal e gênero. 


\section{ANÁLISE UNIDIMENSIONAL - APLICAÇÃO DA REGRA}

\begin{tabular}{|c|c|c|c|}
\hline $\begin{array}{c}\text { Paralelismo } \\
\text { formal/ }\end{array}$ & $\begin{array}{c}\text { Marca de plural } \\
\text { antecedente no 10 } \\
\text { e único elemento } \\
\text { do SN }\end{array}$ & $\begin{array}{c}\text { Marca de plural } \\
\text { antecedente em } \\
\text { dois ou mais } \\
\text { elementos do } \\
\text { SN }\end{array}$ & $\begin{array}{c}\text { Marca zero } \\
\text { antecedente }\end{array}$ \\
\hline Masculino & $522 / 580=90 \%$ & $49 / 53=92 \%$ & $76 / 145=52 \%$ \\
\hline Feminino & $390 / 423=92 \%$ & $101 / 107=94 \%$ & $45 / 89=51 \%$ \\
\hline Total & $912 / 1003=91 \%$ & $150 / 160=94 \%$ & $121 / 234=52 \%$ \\
\hline
\end{tabular}

Tabela 14: Cruzamento entre paralelismo formal oracional e sexo

Analisando a tabela 14 verticalmente, temos percentuais muito próximos de aplicação da regra para o gênero masculino e feminino. Horizontalmente, temos altas frequências de aplicação da regra, tanto para o gênero masculino quanto para o feminino, quando temos marcas de plural antecedente ao verbo.

Quando há uma marca zero antecedente ao verbo, o percentual de aplicação da regra é de $52 \%$ para o gênero masculino e de $51 \%$ para o gênero feminino, comprovando que o paralelismo formal é decisivo para a realização da concordância verbal.

\subsection{VARIÁVEL TRAÇO SEMÂNTICO DO SUJEITO}

Observando a tabela 15 , vemos que os pesos relativos estão próximos a 0.50 , fato que nos esclarece o porquê de tal variável não ter sido selecionada como relevante pelo programa computacional GOLDVARB-X. 


\begin{tabular}{|c|c|c|}
\hline TRAÇO SEMÂNTICO DO SUJEITO & FREQUÊNCIA & PESO RELATIVO \\
\hline [-HUMANO, +ANIMADO] & $11 / 14=79 \%$ & 0.49 \\
\hline [-ANIMADO] & $74 / 99=75 \%$ & 0.38 \\
\hline [+HUMANO] & $432 / 508=85 \%$ & 0.47 \\
\hline
\end{tabular}

Tabela 15: Aplicação da regra para a variável traço semântico do sujeito

Em termos de frequência, a variável [+humano] apresentou $85 \%$ de probabilidade de aplicação da regra.

Porém, pelo fato de os pesos relativos não apresentarem um valor significativo, não podemos dizer que o grupo de fator traço semântico do sujeito é um fator condicionante para a ocorrência da concordância verbal.

Observamos que o traço [+humano] do sujeito foi o que apresentou um número maior de ocorrências 432/508, enquanto os traços [-humano, +animado] e [-animado] não apresentaram um número muito expressivo, 11/14 e 74/99, respectivamente.

Pelos resultados obtidos, parece-nos que a importância do traço semântico do sujeito para o fenômeno da concordância verbal se situa em um plano secundário quando analisado no conjunto das variáveis.

Abaixo apresentamos a tabela 16 com o cruzamento entre paralelismo formal oracional e traço semântico do sujeito, a fim de verificarmos se há uma confluência entre tais grupos de fatores. 


\section{ANÁLISE UNIDIMENSIONAL - APLICAÇÃO DA REGRA}

\begin{tabular}{|c|c|c|c|}
\hline $\begin{array}{c}\text { Paralelismo } \\
\text { formal/ } \\
\text { semaço } \\
\text { sujeito }\end{array}$ & $\begin{array}{l}\text { Marca de plural } \\
\text { antecedente no } 1^{\circ} \\
\text { e único elemento } \\
\text { do } \mathrm{SN}\end{array}$ & $\begin{array}{l}\text { Marca de plural } \\
\text { antecedente em } \\
\text { dois ou mais } \\
\text { elementos do } \\
\text { SN }\end{array}$ & $\begin{array}{l}\text { Marca zero } \\
\text { antecedente }\end{array}$ \\
\hline $\begin{array}{l}\text { [-humano, } \\
\text { +animado] }\end{array}$ & $8 / 8=100 \%$ & $0 / 1=0 \%$ & $3 / 5=60 \%$ \\
\hline [-animado] & $61 / 67=91 \%$ & $6 / 7=86 \%$ & $7 / 25=28 \%$ \\
\hline [+humano] & $342 / 380=90 \%$ & $65 / 68=96 \%$ & $25 / 60=42 \%$ \\
\hline
\end{tabular}

Tabela 16: Cruzamento entre paralelismo formal oracional e traço semântico do sujeito

Com a tabela 16, constatamos que a marca de plural antecedente em dois ou mais elementos do $\mathrm{SN}$ relacionada ao traço [+humano] é um dos fatores condicionantes da presença de concordância verbal, com 96\% de possibilidade de aplicação da regra. Quando há marca zero de plural no termo antecedente, o percentual de aplicação da regra é de apenas $42 \%$.

Observando a tabela, vemos que os percentuais maiores de aplicação da regra de concordância verbal, se dão tanto no traço [-humano, +animado], [-animado] como [+humano], relacionado a marcas antecedentes de plural nos elementos do SN. Já quando há marca zero antecedente os índices de aplicação da regra são baixos, ou seja, há um favorecimento para a ausência da concordância verbal. 
De um modo geral, podemos observar que os percentuais de ausência de concordância verbal são maiores quando o sujeito não é humano.

Diante do exposto, acreditamos que o princípio do paralelismo formal é mais atuante na aplicação da regra de concordância verbal do que o traço semântico do sujeito, uma vez que atua significativamente tanto no sujeito humano como no nãohumano.

\subsection{VARIÁVEL TIPO DE RELATO}

A variável tipo de relato foi uma das variáveis excluídas pelo programa computacional GOLDVARB-X. Abaixo apresentamos a tabela com a frequência e o peso relativo desse grupo de fatores.

\begin{tabular}{|c|c|c|}
\hline TIPO DE RELATO & FREQUENCIA & PESO RELATIVO \\
\hline NARRATIVA DE EXPERIÊNCIA & $312 / 357=87 \%$ & 0.54 \\
\hline PESSOAL & & 0.45 \\
\hline RELATO DESCRITIVO & $161 / 204=80 \%$ & 0.48 \\
\hline RELATO DE PROCEDIMENTO & $48 / 58=83 \%$ & 0.57 \\
\hline RELATO DE OPINIÃO & $347 / 407=85 \%$ & 0.51 \\
\hline
\end{tabular}

Tabela 17: Aplicação da regra segundo a variável tipo de relato

Essa variável se mostrou irrelevante para a realização da concordância verbal por apresentar valores muito próximos de frequência e de peso relativo. Não houve um tipo de relato que tenha se destacado mais que outro. Todos apresentaram resultados muitos próximos. 
Trazemos abaixo o cruzamento entre as variáveis paralelismo formal e tipo de relato.

\section{ANÁLISE UNIDIMENSIONAL - APLICAÇÃO DA REGRA}

\begin{tabular}{|c|c|c|c|}
\hline $\begin{array}{c}\text { Paralelismo } \\
\text { formal/ }\end{array}$ & $\begin{array}{c}\text { Marca de plural } \\
\text { antecedente no 10 } \\
\text { e único elemento } \\
\text { do SN } \\
\text { relato }\end{array}$ & $\begin{array}{c}\text { Marca de plural } \\
\text { antecedente em } \\
\text { dois ou mais } \\
\text { elementos do } \\
\text { SN }\end{array}$ & $\begin{array}{c}\text { Marca zero } \\
\text { antecedente }\end{array}$ \\
\hline $\begin{array}{c}\text { Narrativa de } \\
\text { experiência } \\
\text { pessoal }\end{array}$ & $179 / 195=92 \%$ & $104 / 108=96 \%$ & $29 / 54=54 \%$ \\
\hline $\begin{array}{c}\text { Narratica } \\
\text { recontada }\end{array}$ & $260 / 292=89 \%$ & $16 / 20=80 \%$ & $39 / 59=66 \%$ \\
\hline Relato descritivo & $134 / 148=91 \%$ & $16 / 18=89 \%$ & $11 / 38=29 \%$ \\
\hline $\begin{array}{c}\text { Relato de } \\
\text { procedimento }\end{array}$ & $39 / 43=91 \%$ & ------- & $9 / 15=60 \%$ \\
\hline $\begin{array}{c}\text { Relato de } \\
\text { opinião }\end{array}$ & $300 / 325=92 \%$ & $14 / 14=100 \%$ & $33 / 68=49 \%$ \\
\hline Total & $912 / 1003=91 \%$ & $150 / 160=94 \%$ & $121 / 234=52 \%$ \\
\hline
\end{tabular}

Tabela 18: Cruzamento entre paralelismo formal oracional e tipo de relato

É interessante notar que com o cruzamento entre tipo de relato e paralelismo formal, analisando a tabela acima horizontalmente, o índice de aplicação da regra cai quando temos marca zero antecedente ao verbo. 


\subsection{VARIÁVEL RENDA SÓCIO-ECONÔMICA}

A variável renda sócio-econômica se comportou de forma muito semelhante às demais variáveis excluídas, uma vez que apresentou um percentual e um peso relativo muito próximos uns dos outros para a variável renda de 11 a 24 salários mínimos e para a variável renda de 6 a 10 salários mínimos. Como podemos observar na tabela abaixo:

\begin{tabular}{|c|c|c|}
\hline RENDA SÓCIO-ECONÔMICA & FREQUÊNCIA & PESO RELATIVO \\
\hline DE 11 A 24 SMs & $363 / 430=84 \%$ & 0.47 \\
\hline DE 6 A 10 SMs & $820 / 967=85 \%$ & 0.51 \\
\hline
\end{tabular}

Tabela 19: Aplicação da regra segundo a variável renda sócio-econômica

Embora tenhamos selecionado os informantes da maneira mais uniforme possível, vemos na tabela 22 que os informantes de renda entre 6 a 10 salários mínimos produziram um número maior de ocorrências, envolvendo a concordância verbal (820/967). Porém julgamos que um total de 430 ocorrências para a variável renda de 11 a 24 salários mínimos é um número significativo.

O peso relativo de ambas as variáveis está muito próximo a 0.50 , fato que nos mostra que a renda sócio-econômica não se mostrou influente, não exerce influência decisiva na aplicação da regra.

Para os linguistas Naro \& Lemle (1976), a regra de concordância verbal mostrase, ainda, categórica nas classes média e alta, mas na classe sócio-econômica mais baixa essa regra estaria seguindo um curso evolutivo, em direção a um sistema sem marcas. Vemos claramente com a exposição de nossos resultados, bem como de 
outros linguistas acima elencados, que vivenciamos uma época de fluxo da realização da concordância verbal. Talvez, na época em que o trabalho foi desenvolvido por Naro \& Lemle, a sociedade vivesse num fluxo de ausência de concordância. Supomos que tal fato esteja relacionado com a influência que a escola, a mídia exercem na vida das pessoas, já que atualmente mídia e escola são realidades presentes no cotidiano das pessoas. O uso da norma-padrão se encontra cada vez mais recorrente na nossa sociedade.

Abaixo trago a tabela com o cruzamento entre as variáveis renda sócioeconômica e paralelismo formal.

\section{ANÁLISE UNIDIMENSIONAL - APLICAÇÃO DA REGRA}

\begin{tabular}{|c|c|c|c|}
\hline $\begin{array}{c}\text { Paralelismo } \\
\text { formal/ }\end{array}$ & $\begin{array}{c}\text { Marca de plural } \\
\text { antecedente no 1ㅇ } \\
\text { e único elemento } \\
\text { Renda }\end{array}$ & $\begin{array}{c}\text { Marca de plural } \\
\text { antecedente em } \\
\text { dois ou mais } \\
\text { elementos do } \\
\text { econômica }\end{array}$ & $\begin{array}{c}\text { Marca zero } \\
\text { antecedente }\end{array}$ \\
\hline De 6 a 10 SMs & $672 / 742=91 \%$ & $69 / 73=95 \%$ & $79 / 152=52 \%$ \\
\hline De 11 a 24 SMs & $240 / 261=92 \%$ & $81 / 87=93 \%$ & $42 / 82=51 \%$ \\
\hline Total & $912 / 1003=91 \%$ & $150 / 160=94 \%$ & $121 / 234=52 \%$ \\
\hline
\end{tabular}

Tabela 20: Cruzamento entre paralelismo formal oracional e renda sócio-econômica

Com o cruzamento dessas variáveis, analisando a tabela verticalmente vemos que não há uma variação significativa entre a renda econômica de 6 a 10 salários mínimos e a renda econômica de 11 a 24 salários mínimos. Os percentuais estão sempre muito próximos. 
Analisando a tabela horizontalmente, observamos que há pouca variação quando temos marca de plural antecedente no $1^{\circ}$ e único elemento do $\mathrm{SN}$ ou quando temos marca de plural antecedente em dois ou mais elementos do SN.

Quando temos marca zero antecedente relacionada com renda econômica entre 6 a 10 salários mínimos, encontramos um percentual de aplicação da regra de concordância verbal de apenas $52 \%$. E quando temos marca zero antecedente ao verbo relacionada com renda econômica entre 11 a 24 salários mínimos, nos deparamos com um percentual de $51 \%$ de probabilidade de aplicação da regra de concordância verbal, ou seja, não há uma variação significativa entre os percentuais dessas variáveis.

\subsection{VARIÁVEL PAPEL SEMÂNTICO DO VERBO}

Obtivemos para essa variável, os seguintes resultados:

\begin{tabular}{|c|c|c|}
\hline PAPEL SEMÂNTICO DO VERBO & FREQUÊNCIA & PESO RELATIVO \\
\hline AÇÃO & $487 / 570=85 \%$ & 0.52 \\
\hline PROCESSO & $94 / 102=92 \%$ & 0.65 \\
\hline AÇÃO-PROCESSO & $85 / 104=82 \%$ & 0.28 \\
\hline ESTADO & $56 / 70=80 \%$ & 0.27 \\
\hline
\end{tabular}

Tabela 21: Aplicação da regra segundo a variável papel semântico do verbo

De um modo geral, todos os percentuais se encontram muito próximos uns aos outros. Para verbos de estado temos um percentual de aplicação da regra de concordância verbal de $80 \%$. Os verbos de ação-estado favorecem à concordância 
verbal em $82 \%$. Já os verbos de processo colaboram com a realização da concordância verbal em 92\%, é o tipo de verbo sintático-semântico que menos inibe a ausência de concordância verbal. E os verbos de ação favorecem à concordância verbal em 85\%.

Os pesos relativos dos verbos de ação (0.52) e de processo (0.65) se encontram próximos ao ponto neutro 0.5 , fato que nos esclarece o porquê de tal variável não ter sido selecionada pelo programa computacional GOLDVARB-X, uma vez que sabemos que pesos relativos próximos à 0.5 pouco interferem na ocorrência do fenômeno em estudo, a concordância verbal. Os pesos relativos dos verbos de ação-processo (0.28) e de estado (0.27) mostram uma tendência à ausência de concordância verbal com tais verbos. Supomos que haja tal desfavorecimento pelo fato de verbos de estado selecionarem argumentos inativos, na medida em que o sujeito não é agente, nem causativo, nem paciente. Queremos dizer que o sujeito desses verbos funciona como suporte de propriedades ou como mero experimentador delas. Acreditamos que este fato possa vir a ocasionar o favorecimento à não concordância verbal desses verbos.

1. tem a QUAdra... e os alunos fica mais na QUAdra... (AC 013, L. 66 );

2. as vezes eles fica assim::... (AC 013, L. 139);

3. eles ainda tava no::ivos... (AC 020, L. 67).

Os verbos de ação-processo poderiam favorecer a não concordância verbal pelo fato de atingirem um complemento que expressa uma mudança de estado, de condição ou de posição.

1. mas você sabe né? eles derrubam o mu::ro (AC 109, L. 726); 
2. nada... os o(u)tros que estraga... isso aquilo discaradamente (AC 110, L. 442);

3. eles me(s)mo escreve as próprias leis pra favorecê(r) eles... (AC 110, L. 455).

Como se pôde notar, dentre os fatores linguísticos, os estudos mostram que a variável paralelismo formal é decisiva no uso variável da concordância verbal. Já dentre os fatores sociais, a faixa etária e o grau de escolaridade se revelaram como um dos fatores mais relevantes. Por esse motivo, resolvemos cruzar as variáveis paralelismo formal e grau de escolaridade, o mais significativo estatisticamente, a fim de verificarmos como se dá o comportamento de ambas.

\section{ANÁLISE UNIDIMENSIONAL - APLICAÇÃO DA REGRA}

\begin{tabular}{|c|c|c|c|}
\hline $\begin{array}{c}\text { Paralelismo } \\
\text { formal/ }\end{array}$ & $\begin{array}{c}\text { Marca de plural } \\
\text { antecedente no 10 } \\
\text { e único elemento } \\
\text { do SN }\end{array}$ & $\begin{array}{c}\text { Marca de plural } \\
\text { antecedente em } \\
\text { dois ou mais } \\
\text { elementos do } \\
\text { SN }\end{array}$ & $\begin{array}{c}\text { Marca zero } \\
\text { antecedente }\end{array}$ \\
\hline Encolaridade & $284 / 333=85 \%$ & $34 / 40=85 \%$ & $37 / 83=45 \%$ \\
\hline Ens. Fund. I e II & $309 / 333=93 \%$ & $83 / 87=95 \%$ & $57 / 112=51 \%$ \\
\hline Ens. Superior & $319 / 337=95 \%$ & $33 / 33=100 \%$ & $27 / 39=69 \%$ \\
\hline Total & $912 / 1003=91 \%$ & $150 / 160=94 \%$ & $121 / 234=52 \%$ \\
\hline
\end{tabular}

Tabela 22: Cruzamento entre paralelismo formal oracional e escolaridade

Com o cruzamento entre esses dois grupos de fatores mais relevantes estatisticamente, percebemos que, independentemente da escolaridade, marcas antecedentes influenciam a presença da concordância verbal, uma vez que o 
percentual de aplicabilidade da regra é alto quando se tem um contexto de marcas de plural antecedentes. Já marca zero desfavorece a presença da concordância verbal.

Analisando a tabela horizontalmente, observamos que o ensino superior é a escolaridade que mais favorece ao uso da regra padrão da concordância verbal. Seguido do ensino superior, temos o ensino médio que também apresentou altos índices de concordância verbal. E como o esperado o ensino fundamental l e // foi o que se mostrou menos favorável ao uso da concordância verbal. Ocorrência que nos revela que a escola exerce certa influência na aplicação da concordância verbal, embora as diferenças de percentuais sejam pouco significativas.

De todo modo, devemos lembrar que, independentemente das variáveis linguísticas ou extralinguísticas, obtivemos um percentual alto de concordância verbal $85 \%$, revelando que, de fato, vivenciamos um período de fluxo da ocorrência da concordância verbal. 


\section{ANÁLISE DOS DADOS DA MODALIDADE ESCRITA}

Esperamos que a análise de tais redações possa contribuir para estimular a realização de novas pesquisas e análises do nosso patrimônio linguístico. Ao final dessa pesquisa, será possível perceber as reais manifestações acerca do fenômeno variável da concordância verbal da nossa comunidade, contribuindo, assim, com o próprio ensino do português.

Outro objetivo nosso é investigar os mecanismos que identificam a realidade linguística do português do Brasil na escrita escolar, considerando o fenômeno da concordância verbal, além de verificar se há uma correlação, em termos de uso da língua, entre a modalidade oral e a escrita, no que tange ao fenômeno linguístico da concordância verbal.

Da mesma forma como na modalidade falada, os cálculos estatísticos foram realizados pelo programa computacional GOLDVARB-X.

Analisamos mais de 600 redações do ensino fundamental I ao ensino médio, de modo que nosso corpus é formado por 1031 ocorrências de concordância verbal, sendo 880 ocorrências de aplicação da regra. Essas redações são de alunos que ainda frequentam a escola, o que atesta a importância da variável escolaridade no que tange à aplicação da regra de concordância verbal.

O gráfico apresentado abaixo exibe o percentual de aplicação e não-aplicação da regra padrão de concordância verbal. 


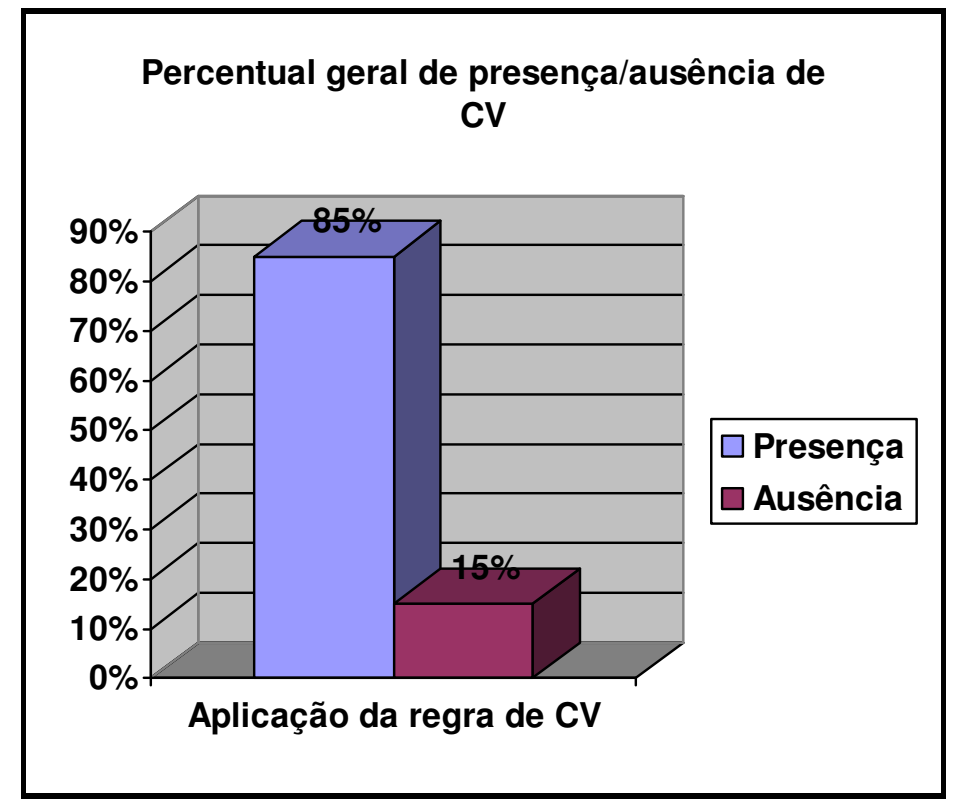

Gráfico 15: Percentual geral de presença/ausência de CV

Os grupos de fatores selecionados pelo programa GOLDVARB-X em ordem de significância foram:

1) Escolaridade;

2) Paralelismo formal;

3) Saliência gráfica;

4) Posição do sujeito.

Os grupos de fatores excluídos pelo programa foram:

1) Classe gramatical do núcleo do sujeito;

2) Presença versus ausência de pronome pessoal (eles/elas).

Nossos dados, como podem ser comprovados no gráfico 15, evidenciam que a concordância verbal, na modalidade escrita na região noroeste do Estado de São Paulo, encontra-se em variação, além de estar havendo uma tendência geral ao uso da regra de concordância verbal. 
Compararemos alguns de nossos resultados com os resultados encontrados por outros linguistas que também estudaram o fenômeno da concordância verbal na escrita escolar. Aquino Silva (1997), em sua dissertação de mestrado, teve como objetivo analisar a variação na concordância verbal, com base em dados extraídos de redações de vestibulares da Universidade de Brasília.

Gameiro (2009) estudou a concordância verbal de $3^{\underline{a}}$ pessoa do plural em redações escolares de uma escola pública de Rio Claro. De modo geral, com a análise dos seus dados, ela constatou que em $84 \%$ das ocorrências há a concordância verbal e em 16\% não há a concordância verbal.

Em sua dissertação de mestrado, Graciliano da Silva (2009) coletou textos narrativos de alunos do $6^{0}$ ao $9^{\circ}$ ano de turmas diurnas em escolas das regiões Zona Oeste e Baixada Fluminense no estado do Rio de Janeiro. Foram analisados 454 dados da modalidade escrita.

Trazemos a seguir um gráfico comparativo entre nossos resultados e os resultados desses linguistas, acima elencados. Cabe ressaltar que nem todas as variáveis linguísticas e extralinguísticas por nós analisadas foram analisadas pelos linguistas acima mencionados. Entretanto aquelas que forem iguais terão seus resultados comparados com os nossos. 


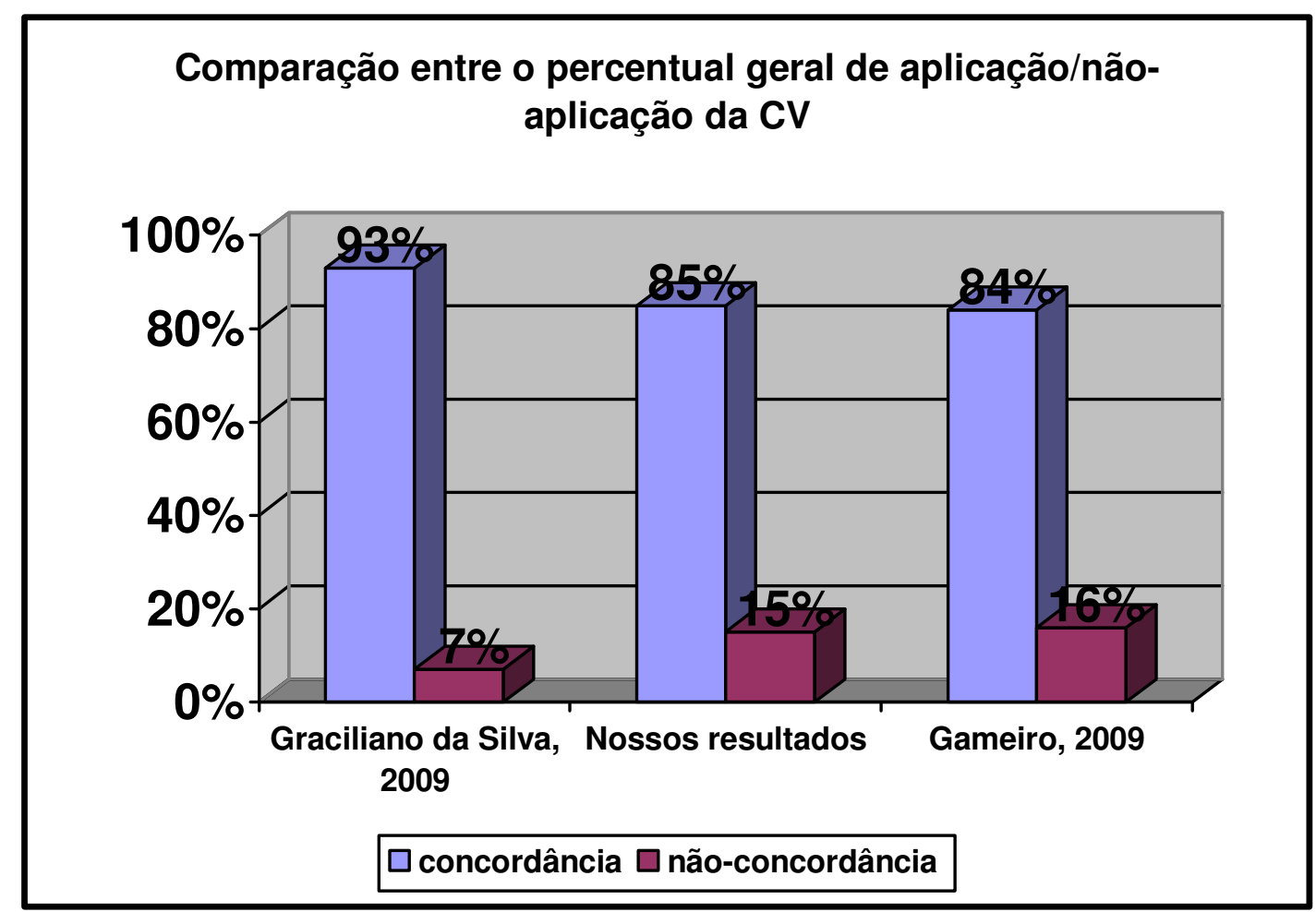

Gráfico 16: Comparação entre os nossos resultados gerais de aplicação versus nãoaplicação da regra de CV, na modalidade escrita, os de Gameiro (2009) e os de Graciliano da Silva (2009)

Julgamos importante comentar que o grupo de fatores classe gramatical do núcleo do sujeito apresentou para as variáveis numeral, pronome demonstrativo, adjetivo e pronome interrogativo duas, quatro, sete e uma ocorrências, respectivamente, com $100 \%$ de concordância verbal. Como os programas que geram o cálculo do peso relativo não trabalham com fatores sem variação, ou seja, quando temos um knockout, foi necessário "eliminar" tais ocorrências. 


\subsection{ESCOLARIDADE}

Para o grupo de fatores escolaridade, encontramos os seguintes resultados:

\begin{tabular}{|c|c|c|}
\hline ESCOLARIDADE & FREQUÊNCIA & PESO RELATIVO \\
\hline ENS. FUNDAMENTAL I & $220 / 289=76 \%$ & 0.24 \\
\hline ENS. FUNDAMENTAL II & $283 / 351=81 \%$ & 0.33 \\
\hline ENSINO MÉDIO & $377 / 391=96 \%$ & 0.81 \\
\hline TOTAL & \multicolumn{2}{|c|}{$880 / 1031=85 \%$} \\
\hline
\end{tabular}

TABELA 23: APLICAÇÃO DA REGRA - ESCOLARIDADE

Com os resultados dessa variável, podemos perceber que quanto mais escolarizados são nossos alunos mais eles farão a concordância exigida pela Gramática Normativa entre sujeito e verbo.

O ensino fundamental I apresentou $76 \%$ de concordância entre sujeito e verbo e como peso relativo 0.24 , o que nos mostra o não favorecimento de aplicação da regra por alunos com pouca escolaridade.

O ensino fundamental II apresentou $81 \%$ de concordância entre sujeito e verbo contra $96 \%$ de concordância do ensino médio. Em pesos relativos temos o ensino fundamental II com 0.33 e o ensino médio com 0,81 , deixando clara a influência que a escola exerce em nossos alunos. Esses dados nos indicam que a rápida passagem pela escola não garante o aprendizado das regras de concordância verbal padrão, é necessário um contato maior para que os alunos utilizem a regra padrão.

Diferenças quanto ao grau de escolaridade dos informantes se revelaram significativamente atuantes na variação da concordância verbal, como nos mostram os índices na tabela 23. 
A variável escolaridade da modalidade escrita pode nos ajudar a compreender 0 porquê da faixa etária 7-15 anos, da modalidade falada, apresentar uma probabilidade tão alta $(0,86$ - 95\%) de aplicação da regra, uma vez que nossas redações são justamente de jovens entre 7 a 17 anos (ensino fundamental I a ensino médio) e que, em termos gerais, apresentam $85 \%$ de aplicação da regra.

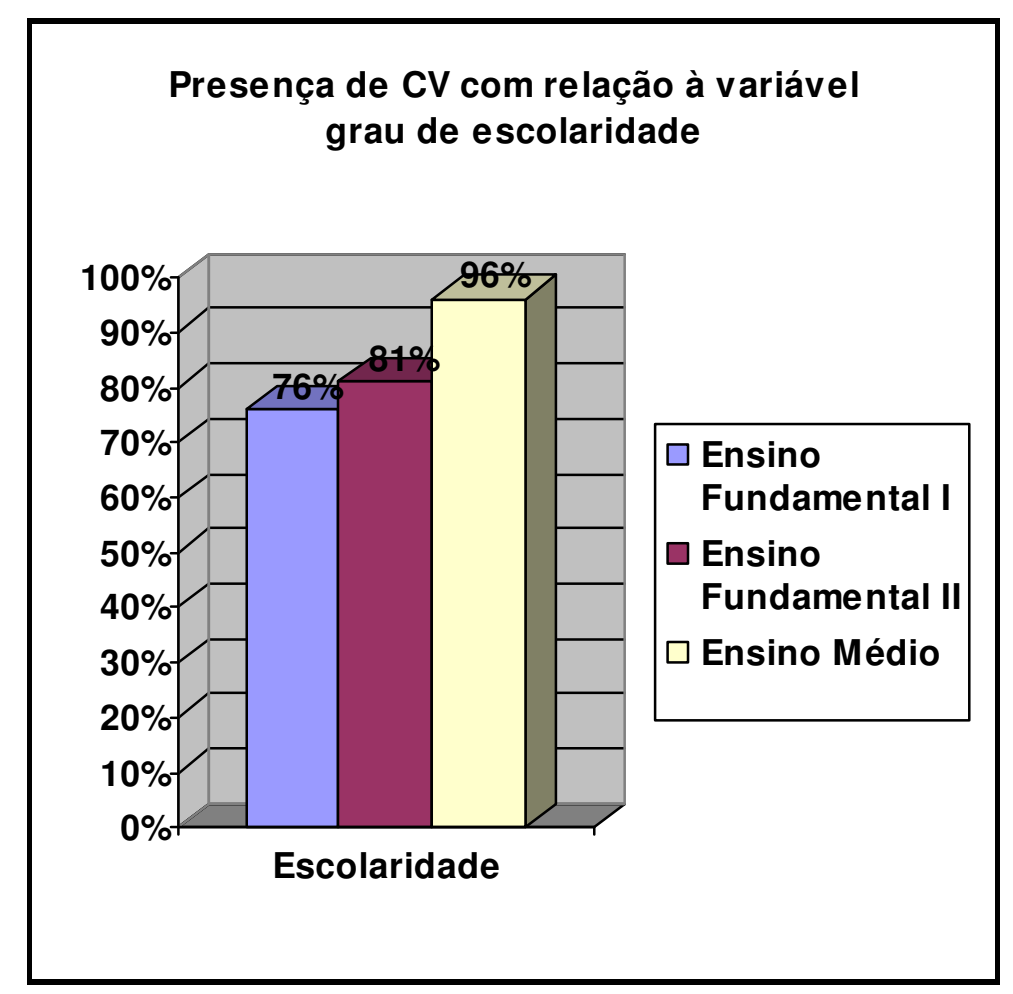

Gráfico 17: Aplicação de CV de acordo com a variável escolaridade

Dentre outros traços, a escola propõe um padrão culto de realização da regra de concordância verbal, e os alunos tendem a assimilar tal traço até o final do ensino médio. 


\subsection{PARALELISMO FORMAL ORACIONAL}

Esta variável mostrou que também, na modalidade escrita, marcas antecedentes ao verbo tendem a levar o verbo para o plural, enquanto a ausência de tais marcas tende a deixar o verbo no singular.

\begin{tabular}{|c|c|c|}
\hline PARALELISMO FORMAL & FREQUÊNCIA & PESO RELATIVO \\
\hline $\begin{array}{c}\text { MARCA DE PLURAL } \\
\text { ANTECEDENTE }\end{array}$ & $727 / 827=88 \%$ & 0.60 \\
\hline MARCA ZERO & $153 / 204=75 \%$ & 0.15 \\
ANTECEDENTE & & \\
\hline
\end{tabular}

TABELA 24: APLICAÇÃO DA REGRA - PARALELISMO FORMAL

Em $88 \%$ das ocorrências em que havia presença de marca formal de plural antecedente ao verbo houve aplicação da regra de concordância verbal. O peso relativo $(0,60)$ dos fatores só confirma que a probabilidade de o verbo vir no plural é maior quando ele é antecedido por um constituinte do SN no plural.

1. As mininas são lindas (Ens. Fund. I);

2. Eu sei que as coisas estão boas pra você (Ens. Fund. II);

3. Os países estão empenhados (Ens. Médio).

Já quando a ausência de plural antecede o verbo, a probabilidade de aplicação da regra é de apenas 0,15 , ou seja, há uma forte tendência de o verbo vir no singular.

1. Os animal gostou da Branca de Neve. (Ens. Fund. I);

2. Pois as coisa aqui fora não está muito fáceis não. (Ens. Fund. II); 
3. As pessoa que são levadas à pena de morte, muitas vezes não teve a consciência do ato. (Ens. Médio).

Diante do exposto, podemos afirmar que a concordância verbal, com relação ao paralelismo formal, se comporta de maneira muito semelhante nas modalidades falada e escrita, já que, em ambas, marcas levaram a marcas e zeros levaram a zeros.

Como se pôde notar, dentre os fatores linguísticos, os estudos mostram que, na modalidade escrita, o grupo de fatores paralelismo formal, como na modalidade falada, também é decisivo no uso da concordância verbal. Já dentre os fatores sociais, o grupo de fatores escolaridade se mostrou como um dos grupos de fatores mais relevantes.

Abaixo apresentamos o cruzamento dessas duas variáveis.

\section{ANÁLISE UNIDIMENSIONAL - APLICAÇÃO DA REGRA}

\begin{tabular}{|c|c|c|c|}
\hline Escolaridade & $\begin{array}{c}\text { Ensino } \\
\text { Fundamental I }\end{array}$ & $\begin{array}{c}\text { Ensino } \\
\text { Fundamental II }\end{array}$ & Ensino Médio \\
\hline $\begin{array}{c}\text { Presença de plural } \\
\text { no elemento } \\
\text { antecedente }\end{array}$ & $210 / 260=81 \%$ & $255 / 293=87 \%$ & $262 / 274=96 \%$ \\
\hline $\begin{array}{c}\text { Ausência de plural } \\
\text { no elemento } \\
\text { antecedente }\end{array}$ & $10 / 29=34 \%$ & $28 / 58=48 \%$ & $112 / 117=96 \%$ \\
\hline Total & $220 / 289=76 \%$ & $283 / 351=81 \%$ & $374 / 391=96 \%$ \\
\hline
\end{tabular}

Tabela 25: Cruzamento entre escolaridade e paralelismo formal na modalidade escrita 
Analisando a tabela horizontalmente, nos deparamos com um resultado previsível: as marcas de plural aumentam conforme aumenta a escolaridade do aluno, isso porque há uma forte influência da escola na escrita escolar, pois é justamente, na escola, que o aluno entra em contato com as normas gramaticais, assim como, por exemplo, o fenômeno da concordância verbal.

Observando a tabela verticalmente, temos que o ensino fundamental I é o fator que menos concorda quando há ausência de plural no elemento antecedente ao verbo, com apenas 34\% de possibilidade de ocorrer a concordância verbal. Em seguida está o ensino fundamental /l com $48 \%$ de aplicação da regra.

Conforme a escolaridade do aluno aumenta, a diferença entre a aplicação da regra quando se tem ausência de marcas antecedentes ao verbo diminui, levando-nos a crer que a escola torna o aluno mais "sensível" ao fenômeno da concordância verbal.

O ensino médio apresenta o mesmo percentual de aplicação da regra para presença de plural no elemento antecedente ao verbo e para ausência de plural no elemento anterior ao verbo $96 \%$. Fato que nos mostra que é somente na escola que o indivíduo tem um amadurecimento com relação ao uso da concordância verbal.

\subsection{SALIÊNCIA FÔNICA/GRÁFICA}

Chamaremos esta variável de saliência gráfica, da mesma forma como faz Aquino Silva (1997), já que se trata de um corpus escrito. 


\begin{tabular}{|c|c|c|}
\hline SALIÉNCIA GRÁFICA & FREQUÊNCIA & PESO RELATIVO \\
\hline FALAVA/FALAVAM & $183 / 209=88 \%$ & 0.46 \\
\hline FAZ/FAZEM & $33 / 39=85 \%$ & 0.35 \\
\hline ESTÁ/ESTÃO & $70 / 74=95 \%$ & 0.70 \\
\hline FALOU/FALARAM & $46 / 59=78 \%$ & 0.46 \\
\hline TROUXE/TROUXERAM & $18 / 25=72 \%$ & 0.34 \\
\hline É/SÃO & $89 / 93=96 \%$ & 0.86 \\
\hline
\end{tabular}

TABELA 26: APLICAÇÃO DA REGRA - SALIÊNCIA GRÁFICA

As formas verbais do pretérito irregular com variação do grau de abertura da vogal tônica, em ambas as formas do singular e do plural (trouxe/ trouxeram) e as formas verbais que, em geral, diferenciam o singular do plural pela adição de uma vogal ou ditongo nasalizados (faz/fazem) também favorecem a não-aplicação da regra em 0.34 e 0.35, respectivamente. Acreditamos que uma das razões de termos uma diferença percentual tão grande entre os dados da modalidade falada e os da modalidade escrita está no fato de as formas verbais trouxe/trouxeram serem irregulares, de modo que só serão ensinadas aos alunos à medida que eles tiverem um maior contato com a escola. E como vimos, para a modalidade falada, o grupo de fatores escolaridade foi o que se mostrou mais relevante, fato que confirma o papel decisivo que a escola exerce sobre o modo de falar e escrever do aluno.

A classe dos pretéritos perfeitos regulares (falou/falaram; aprendeu/ aprenderam; dormiu/dormiram) se mostrou neutra, com um peso relativo de 0.46 , com relação à aplicação da regra de concordância verbal.

As classes que mais favoreceram o uso da regra padrão de concordância foram as formas dos verbos cujo elemento vocálico tônico oral no singular contrasta com o ditongo tônico nasal no plural (está/estão; vai/vão; dá/dão) e o verbo ser (é/são), caso 
único do presente do indicativo, com uma porcentagem de $95 \%$ e $96 \%$ e com um peso relativo de 0.70 e 0.86 , respectivamente. Acreditamos que essa grande probabilidade de aplicação da regra, para tais verbos, está no fato de serem muito usados na língua portuguesa, de modo que tais formas verbais já se encontram cristalizadas na mente dos alunos, tornando-se, assim, mais perceptíveis.

Pelo fato de a variável escolaridade ter se mostrado como a mais relevante, em nosso corpus da modalidade escrita, realizamos o cruzamento entre essa variável e a saliência gráfica, a fim de verificarmos o comportamento dessa junção.

\section{ANÁLISE UNIDIMENSIONAL - APLICAÇÃO DA REGRA}

\begin{tabular}{|c|c|c|c|}
\hline Escolaridade & $\begin{array}{c}\text { Ensino } \\
\text { Fundamental I }\end{array}$ & $\begin{array}{c}\text { Ensino } \\
\text { Fundamental II }\end{array}$ & Ensino Médio \\
saliência gráfica & & & \\
\hline Falava/falavam & $24 / 31=77 \%$ & $53 / 71=75 \%$ & $106 / 107=99 \%$ \\
\hline Quer/querem & $1 / 2=50 \%$ & $18 / 23=78 \%$ & $14 / 14=100 \%$ \\
\hline Está/estão & $1 / 1=100 \%$ & $37 / 41=90 \%$ & $32 / 32=100 \%$ \\
\hline Falou/falaram & $29 / 40=72 \%$ & $8 / 10=80 \%$ & $9 / 9=100 \%$ \\
\hline Trouxe/trouxeram & $10 / 15=67 \%$ & $5 / 6=83 \%$ & $3 / 4=75 \%$ \\
\hline É/são & $44 / 45=98 \%$ & $23 / 26=88 \%$ & $22 / 22=100 \%$ \\
\hline
\end{tabular}

Tabela 27: Cruzamento entre escolaridade e saliência gráfica

Analisando a tabela horizontalmente, observamos que, de modo geral, o ensino médio é o contexto favorável para a realização da concordância verbal. Notamos ainda que há um aumento da realização da concordância verbal à medida que a escolaridade 
do informante aumenta. Em outras palavras, à proporção que a escolaridade aumenta, cresce também o percentual do uso da concordância verbal.

Observando a tabela verticalmente, temos, para a variável escolaridade ensino fundamental $I$, o verbo é/são como o mais favorável à aplicação da regra da concordância verbal, com 98\%, ao lado de está/estão com 100\% de aplicação da regra, porém por ter apresentado uma amostragem pequena (houve apenas um único caso) não o consideraremos.

O ensino fundamental I/ apresentou o verbo está/estão como o mais favorecedor à aplicação da concordância verbal, com 90\% de realização da regra.

Já o ensino médio apresentou diversos verbos como propícios à realização da concordância verbal como, por exemplo, quer/querem, está/estão, falou/falaram e é/são todos com $100 \%$ de aplicação da regra e, muito próximo ao $100 \%$, aparece o verbo falava/falavam com 99\% de aplicação da concordância verbal.

Diante do exposto, concluímos que a escola desempenha uma forte influência na escrita escolar, de modo que o aluno se aperfeiçoa à medida que avança na escola.

Observamos que quanto mais perceptível e familiarizada a diferença verbal entre singular/plural, mais chances o verbo terá de aparecer no plural, fazendo a devida concordância com seu sujeito.

No entanto, tal comportamento não é categórico, haja vista termos uma oscilação entre o percentual de aplicação da regra de CV de algumas formas verbais, como podemos observar no gráfico a seguir. 


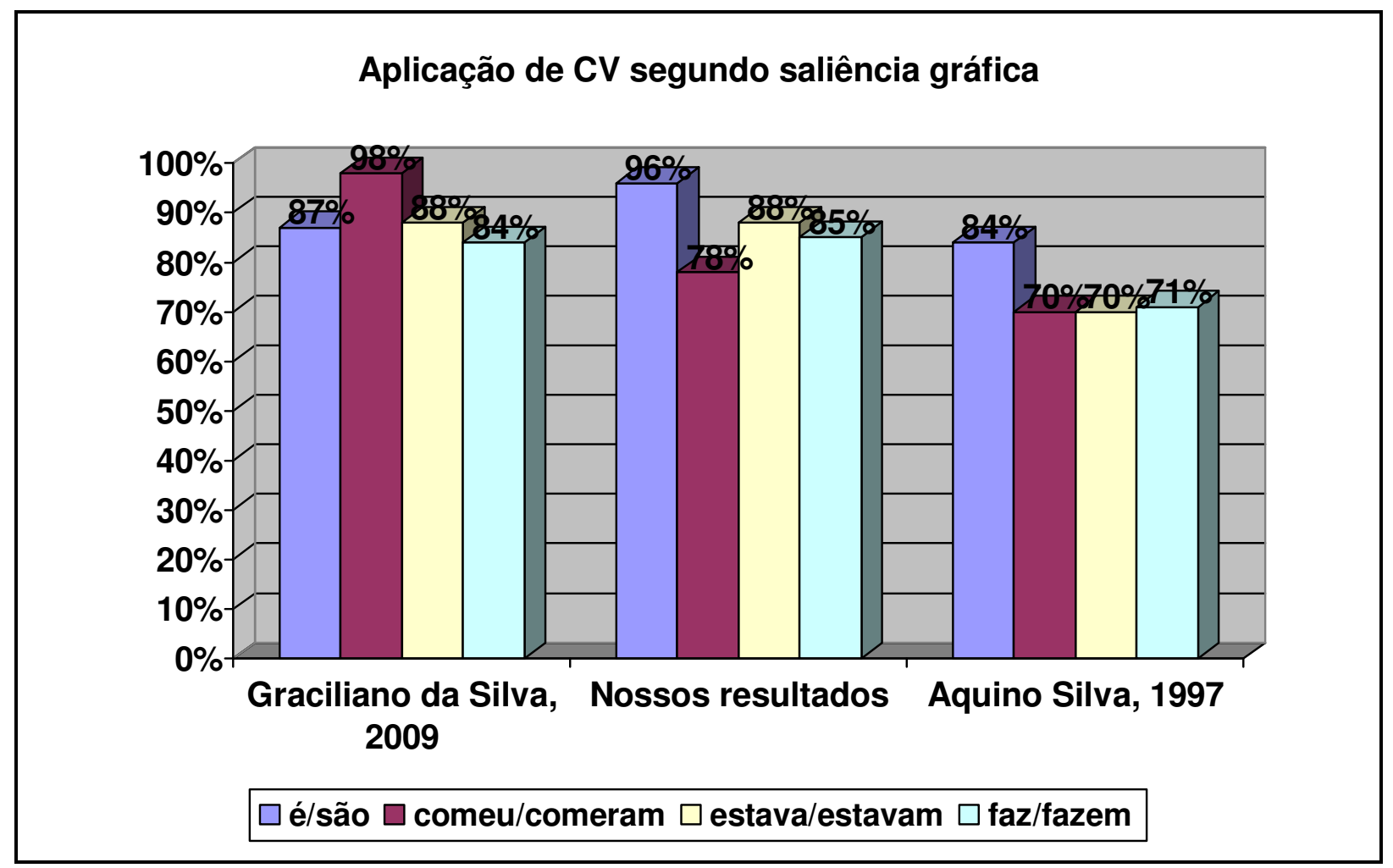

Gráfico18: Gráfico contrastivo entre os nossos resultados, os de Graciliano da Silva (2009) e os de Aquino Silva (1997)

Sabemos, como foi comprovado ao longo desta pesquisa, que o fenômeno da CV é bastante explorado na modalidade falada e pouco explorado na modalidade escrita. Mesmo diante de tal circunstância, compararemos nossos resultados com os de outras pesquisas, mesmo sabendo que nem todos os corpora são iguais aos nossos. Devemos frisar que Graciliano da Silva (2009) estudou apenas redações do 6ำ ao 9ำ ano, ou seja, ensino fundamental II e Aquino Silva (1997) analisou redações de vestibular. Vejamos como a variável saliência gráfica se comportou em cada um destes corpus.

Os resultados de Graciliano da Silva nos mostram que até mesmo os alunos do ensino fundamental II percebem a diferença gráfica/fônica entre as formas verbais do singular e plural, uma vez que as formas mais perceptíveis, mais salientes, como é/são 
e comeu/comeram, mostraram-se, de fato, mais propícias para a marcação do plural (87\% e 98\%, respectivamente) do que as menos perceptíveis, menos salientes, como faz/fazem (84\%). Devemos, é claro, salientar que não temos um grande percentual de variação entre tais formas verbais, com exceção da forma comeu/comeram que apresentou 98\% de aplicação da regra padrão.

Nos dados de Aquino Silva (1997), as formas verbais comeu/comeram, estava/estavam e faz/fazem apresentaram índices de concordância, praticamente, idênticos (70\%, 70\% e 71\%, respectivamente). A forma verbal é/são apresentou $84 \%$ de aplicação da regra de CV. Intriga-nos o fato de que, em um corpus de redações de vestibular, o percentual de aplicação da regra de CV segundo a variável saliência gráfica tenha sido menor do que o percentual de redações do ensino fundamental II, já que acreditávamos que quanto maior o contato que o aluno tivesse com a escola, maior seria o uso da regra padrão. Diante de tais resultados, acreditamos que seria necessário um estudo mais aprofundado do perfil social destes informantes, e, como não temos acesso a tais informantes, esperamos que outros pesquisadores, talvez do Rio de Janeiro e de Brasília, local onde essas duas pesquisas foram desenvolvidas, se aprofundem mais a respeito do porquê de tal contraste.

Retomando a idéia de que vivenciamos um período de fluxo da realização da CV, os resultados expostos acima nos evidenciam que, de fato, a presença da concordância verbal está instaurando-se em nosso meio, e o exemplo disto é que desde o ensino fundamental há uma tendência ao uso da regra padrão de CV. 


\subsection{POSIÇÃO DO SUJEITO}

Em termos percentuais o sujeito anteposto favorece a aplicação da regra em $87 \%$, enquanto o sujeito posposto favorece somente em $61 \%$. No entanto, o peso relativo de ambas as variantes é muito próximo, já que sujeito anteposto apresentou como peso relativo o índice de 0.43 e o sujeito posposto o peso relativo de 0,40 . Números muito próximos do peso relativo 0.50 , ponto de neutralidade.

\begin{tabular}{|c|c|c|}
\hline POSIÇÃO DO SUJEITO & FREQUÊNCIA & PESO RELATIVO \\
\hline ANTEPOSTO & $719 / 830=87 \%$ & 0.43 \\
\hline POSPOSTO & $59 / 97=61 \%$ & 0.40 \\
\hline
\end{tabular}

TABELA 28: APLICAÇÃO DA REGRA - POSIÇÃO DO SUJEITO

Exemplificando o sujeito anteposto, temos:

1. Os sete anões chegaram. (Ens. Fund. I);

2. Minhas amigas iriam todas de vestido vermelho. (Ens. Fund. II);

3. Muitas críticas são feitas. (Ens. Médio).

Trazemos também alguns exemplos de sujeito posposto:

1. Aí chegou os anões da Branca de Neve. (Ens. Fund. I);

2. Como se formou todos os planetas. (Ens. Fund. II);

3. Então acabará os recursos naturais. (Ens. Médio).

Como afirma Decat (1983), sujeitos antepostos ao verbo favorecem a aplicação da regra, e quando o sujeito está posposto ao verbo, há um desfavorecimento de aplicação da regra padrão de concordância verbal. 
A ausência de concordância verbal com SN posposto, tanto na modalidade falada quanto na escrita, e sua comparação com ocorrências com SN anteposto, nas quais se efetua a concordância verbal, levaram-nos a crer que não se trata de um simples desconhecimento da regra ou de um problema de distinção fônica entre as formas singular e plural do verbo, pois se assim fosse teríamos $100 \%$ de ausência da regra nesses casos. O fato é que tanto na modalidade falada quanto na escrita, quando há um SN posposto ao verbo, ora há a aplicação da regra de concordância verbal, ora não há. Segundo Decat (1983), esse caráter optativo da concordância verbal com SN posposto pode dever-se a um fenômeno de evolução da língua e que passa despercebido, pois as duas formas coexistem, até o momento em que uma delas irá sobrepujar a outra.

Pontes (1986), em estudo sobre o sujeito, postula que o chamado "sujeito posposto" não assume as características básicas desse termo da oração. Antes, "as características desse SN posposto coincidem é com o objeto direto em português." (PONTES, 1986, p.52).

Naro \& Lemle (1977, p.263) explicam que

é menos provável que o verbo receba marcas de plural quando o sujeito plural ocorre, linearmente, depois do verbo, caso em que a falta de concordância torna-se menos perceptível pelo fato de que o elemento determinante segue o elemento determinado.

Assim, ampliando-se o sentido do princípio da saliência, pode-se afirmar que a posposição do sujeito ao verbo é menos saliente do que a anteposição, desfavorecendo, por isso, a concordância. 
Para demonstrar que o sujeito posposto, realmente, é sentido como objeto direto pelo aluno, apresentamos a tabela abaixo, com o cruzamento entre as variáveis posição do sujeito e escolaridade.

ANÁLISE UNIDIMENSIONAL - APLICAÇÃO DA REGRA
\begin{tabular}{|l|c|c|}
\hline $\begin{array}{l}\text { POSIÇÃO SUJEITO/ } \\
\text { ESCOLARIDADE }\end{array}$ & ANTEPOSTO & POSPOSTO \\
\hline $\begin{array}{l}\text { ENS. } \\
\text { FUNDAMENTAL I }\end{array}$ & $204 / 257=79 \%$ & $6 / 20=30 \%$ \\
\hline $\begin{array}{l}\text { ENS. } \\
\text { FUNDAMENTAL II }\end{array}$ & $253 / 299=85 \%$ & $24 / 46=52 \%$ \\
\hline ENSINO MÉDIO & $262 / 274=96 \%$ & $29 / 31=94 \%$ \\
\hline
\end{tabular}

Tabela 29: Cruzamento entre posição do sujeito e escolaridade

Observamos que, quando temos a posposição do sujeito, a aplicação da regra é proporcional à escolaridade do aluno, pois somente em séries mais avançadas, o aluno tem uma percepção maior do que de fato é objeto ou sujeito da oração. O ensino médio apresenta o maior índice de aplicação da regra para sujeito posposto (94\%), por exemplo. Ao contrário, no ensino fundamental lé a variável que menos consciência tem do sujeito posposto, já que é a classe que realiza menos concordância verbal neste contexto, apenas $30 \%$ dos casos aparecem com a marca de plural nos verbos.

A seguir apresentamos os grupos de fatores que não foram selecionados pelo programa estatístico GOLDVARB-X. 


\subsection{VARIÁVEIS EXCLUÍDAS}

Não foram selecionados, pelo programa computacional GOLDVARB-X, os grupos de fatores classe gramatical do núcleo do sujeito e presença versus ausência de pronome pessoal.

Para a variável presença versus ausência de pronome pessoal temos, muito próximos, os pesos relativos e a porcentagem, já que a presença do pronome favorece em $82 \%$ e em peso relativo 0.48 , enquanto a ausência favorece em $86 \%$ e em peso relativo 0.47 .

\begin{tabular}{|c|c|c|}
\hline PRONOME PESSOAL & FREQUENCIA & PESO RELATIVO \\
\hline PRESENÇA & $89 / 109=82 \%$ & 0.48 \\
\hline AUSÊNCIA & $345 / 403=86 \%$ & 0.47 \\
\hline
\end{tabular}

Tabela 30: Aplicação da regra de CV segundo a variável pronome pessoal

De modo que essa variável não constitui fator decisivo para o uso de formas verbais marcadas.

1. Eles se beijaram. (Ens. Fund. I);

2. Eles são muito ciumentos. (Ens. Fund. II);

3. Elas vivem muito individualmente. (Ens. Médio).

4. Os sete anões falou que este é o meu marido. (Ens. Fund. I);

5. Os pastéis de lá são muito gostosos. (Ens. Fund. II);

6. Os casamentos não duram mais tanto tempo. (Ens. Médio); 
Ambas as variantes encontram-se próximas do ponto neutro 0.50 , pouco influenciando na aplicação da regra de CV.

Apresento abaixo o cruzamento entre as variáveis escolaridade e pronome pessoal.

\section{ANÁLISE UNIDIMENSIONAL - APLICAÇÃO DA REGRA}

\begin{tabular}{|c|c|c|c|}
\hline Escolaridade & $\begin{array}{c}\text { Ensino } \\
\text { Fundamental I }\end{array}$ & $\begin{array}{c}\text { Ensino } \\
\text { Fundamental II }\end{array}$ & Ensino Médio \\
Pronome pessoal & & & \\
\hline Presença & $36 / 50=72 \%$ & $43 / 49=88 \%$ & $10 / 10=100 \%$ \\
\hline Ausência & $74 / 97=76 \%$ & $95 / 123=77 \%$ & $176 / 183=96 \%$ \\
\hline
\end{tabular}

Tabela 31: Cruzamento entre escolaridade e pronome pessoal

A partir do cruzamento entre essas duas variáveis, nos torna possível observar que tanto a presença quanto a ausência do pronome pessoal do caso reto (eles/elas) provocam um aumento conforme aumenta a escolaridade do informante.

Observando o comportamento da variável ensino fundamental $I$, temos que a ausência do pronome pessoal favorece a concordância verbal em $76 \%$. Ao contrário, o ensino fundamental // e o ensino médio apresentam como variável que mais favorece a presença da concordância verbal a presença do pronome pessoal, com $88 \%$ e $100 \%$, respectivamente. 


\begin{tabular}{|c|c|c|}
\hline $\begin{array}{c}\text { CLASSE GRAMATICAL DO } \\
\text { NÚCLEO DO SUJEITO }\end{array}$ & FREQUENCIA & PESO RELATIVO \\
\hline PRONOME PESSOAL & $89 / 109=82 \%$ & 0.37 \\
\hline SUBSTANTIVO & $215 / 259=83 \%$ & 0.40 \\
\hline PRONOME INDEFINIDO & $73 / 85=86 \%$ & 0.37 \\
\hline PRONOME OCULTO & $102 / 104=98 \%$ & 0.92 \\
\hline NUMERAL & $6 / 7=86 \%$ & 0.67 \\
\hline
\end{tabular}

Tabela 32: Aplicação da regra segundo a variável classe gramatical do núcleo do sujeito

Com relação à classe gramatical do núcleo do sujeito, a classe pronome oculto foi a que mais favoreceu a aplicação da regra, apresentando um percentual de $98 \%$ e um peso relativo de 0.92 . Acreditamos que pelo fato de o sujeito estar oculto, para retomarmos o sujeito plural que apareceu anteriormente na oração, ocorre a concordância com o sujeito, mesmo quando este não aparece explicitamente, daí termos uma alta porcentagem de aplicação da regra para sujeitos ocultos.

1. $\varnothing \mathrm{E}$ foram felizes para sempre. (Ens. Fund. I);

2. $\varnothing$ Pra poderem fazer a maior farra. (Ens. Fund. II);

3. $\varnothing$ Estão ficando mais violentas. (Ens. Médio).

Em seguida, temos a classe dos numerais com $86 \%$ de concordância e peso relativo 0,67 de aplicação da regra. 
1. Os sete foram dormir. (Ens. Fund. I);

2. Mais de dez serão convidados. (Ens. Fund. II);

3. Quase $2 / 4$ são jogados fora. (Ens. Médio).

Próxima ao ponto neutro (0.50), temos a classe dos substantivos com $83 \%$ e 0.40 de peso relativo, o que mostra a não influência dessa classe na aplicação da regra.

1. Meus amigos são legais. (Ens. Fund. I);

2. Os estudos são a base na vida de uma pessoa. (Ens. Fund. II);

3. Os países estão empenhados. (Ens. Médio).

Com pesos relativos idênticos, temos a classe dos pronomes pessoais e a dos pronomes indefinidos ambas com 0.37. Em termos percentuais os pronomes pessoais apresentam $82 \%$ de aplicação da regra e os pronomes indefinidos $86 \%$ de aplicação da regra.

1. Eles era um pouquinho malvados. (Ens. Fund. I);

2. Eles um dia vão virar realidade. (Ens. Fund. II);

3. Elas vão se tornando mais agressivas. (Ens. Médio);

4. Todos vivem com um melhor amigo. (Ens. Fund. I);

5. Todas são para o seu bem. (Ens. Fund. II);

6. Todos podem se arrepender. (Ens. Médio). 
De modo geral, podemos dizer que sujeito oculto favorece o uso de formas verbais marcadas, ou seja, a presença de concordância, pois é nas estruturas com o sujeito oculto que o uso da forma verbal marcada em número e pessoa serviria de único índice formal e semântico do sujeito da oração.

Apresentamos abaixo a tabela 33 com o cruzamento das variáveis escolaridade e classe gramatical do núcleo do sujeito.

\section{ANÁLISE UNIDIMENSIONAL - APLICAÇÃO DA REGRA}

\begin{tabular}{|c|c|c|c|}
\hline Escolaridade & $\begin{array}{c}\text { Ensino } \\
\text { Fundamental I }\end{array}$ & $\begin{array}{c}\text { Ensino } \\
\text { Fundamental II }\end{array}$ & Ensino Médio \\
$\begin{array}{c}\text { Classe } \\
\text { gramatical } \\
\text { do núcleo do } \\
\text { sujeito }\end{array}$ & & & \\
\hline $\begin{array}{c}\text { Pronome pessoal } \\
\text { Pronome indefinido }\end{array}$ & $36 / 50=72 \%$ & $43 / 49=88 \%$ & $10 / 10=100 \%$ \\
\hline Numeral & $22 / 31=71 \%$ & $22 / 25=88 \%$ & $29 / 29=100 \%$ \\
\hline Substantivo & $46 / 59=78 \%$ & $66 / 90=73 \%$ & $103 / 110=94 \%$ \\
\hline Pronome oculto & $26 / 39=67 \%$ & $28 / 31=90 \%$ & $12 / 12=100 \%$ \\
\hline
\end{tabular}

Tabela 33: Cruzamento entre escolaridade e classe gramatical do núcleo do sujeito

\footnotetext{
${ }^{16}$ Devemos ressaltar que o número de ocorrências com numeral foi baixo, acreditamos que o resultado poderia ser outro, caso tivéssemos mais ocorrências com tal estrutura sintática. Sendo assim não consideraremos tal resultado em nossa pesquisa.
} 
De modo geral, a presença da concordância verbal foi mais uma vez motivada pela escolaridade, já que temos um aumento das marcas de plural à proporção que temos um aumento da escolaridade do informante.

O ensino fundamental I mostrou a classe dos substantivos como a mais propícia para a ocorrência da concordância verbal com $78 \%$.

O ensino fundamental I/ apresentou o mesmo percentual (88\%) de aplicação da regra para as variáveis pronome pessoal e pronome indefinido. Para pronome oculto apresentou $90 \%$ de probabilidade de aplicação da regra de CV. Da mesma maneira se comportou o ensino médio, só alterando a porcentagem de aplicação da regra para as variáveis pronome pessoal, pronome oculto e pronome indefinido para $100 \%$.

Constatamos que, pelo fato de a variável presença/ausência do pronome pessoal e a variável classe gramatical do núcleo do sujeito terem sido excluídas pelo programa computacional GOLDVARB-X, a constituição morfológica do sujeito oracional das redações escolares não influencia significativamente na realização da concordância verbal. A concordância verbal é condicionada, na modalidade escrita, por outras variáveis, não pela constituição morfológica do sujeito. 


\section{CONCLUSÃO}

Por meio de um estudo sincrônico e quantitativo, analisamos a variação na concordância verbal de $3^{\text {a }}$ pessoa do plural na fala de 24 pessoas residentes na cidade de São José do Rio Preto, localizada no interior do Estado de São Paulo. Também analisamos mais de 600 redações escolares de alunos que estão entre $01^{\circ}$ ano do ensino fundamental I ao 3o ano do ensino médio na cidade de São José do Rio Preto.

Vimos que a regra de concordância verbal, na região noroeste paulista, tanto na modalidade falada quanto na escrita, é uma regra sujeita a variações. Nesse processo de variação, verificamos um predomínio geral da variante prestigiada, ou seja, a presença da concordância verbal, em ambas as modalidades temos um percentual de $85 \%$ de aplicação da regra.

Por meio da análise estatística por nós realizada, percebemos que estamos diante de um caso de variação e que essa variação não é aleatória. De acordo com Scherre e Naro (1998), é possível prever em que estruturas linguísticas e em que situações sociais os falantes são mais propensos a colocar ou não a marca formal de plural no verbo. É, portanto, uma variável linguística condicionada tanto por fatores linguísticos, como por fatores sociais.

Percebemos ao longo da pesquisa que há uma intrínseca relação entre fatores linguísticos e extralingüísticos no processo de variação da concordância verbal.

Observamos, na seção 3, que, até mesmo nas gramáticas normativas, que normalmente apresentam normas rígidas a serem seguidas, a variação da concordância verbal é reconhecida, uma vez que os próprios gramáticos, baseados em exemplos da tradição literária, admitem o uso do verbo no singular ou no plural em muitos casos. 
Conforme a análise estatística realizada, os grupos de fatores que revelaram maior influência sobre a concordância verbal, na modalidade falada, foram paralelismo formal, distância e posição do sujeito, faixa etária, escolaridade e saliência fônica e estrutura do sujeito. Já os grupos de fatores que revelaram maior influência sobre a concordância verbal, na modalidade escrita, foram escolaridade, paralelismo formal, saliência gráfica e posição do sujeito.

Devido aos altos índices de aplicação da regra de CV, acreditamos que a língua esteja em um fluxo de predomínio de marcação da concordância verbal, como vimos nos trabalhos de Monguilhott 2001, Monguilhott 2009, Silvia Vieira 1995, Scherre 1988.

Como afirma Scherre (1998), o comportamento da concordância é parte de uma nova direção nos fluxos e contrafluxos da variação. Neste momento, o sistema de áreas urbanas evidencia uma tendência em direção a marcas redundantes. Não se trata de preservação da informação, em termos de economia estrutural linguística. Em verdade, tanto a redundância quanto a não-redundância podem resultar de um principio mais geral, o principio do paralelismo linguístico, que é a tendência de formas da mesma natureza ocorrerem juntas.

Tanto a modalidade escrita quanto a falada podem se apresentar de diversas formas, porém no ensino da modalidade escrita busca-se neutralizar as marcas identificadoras de cada grupo social, no intuito de atingir um padrão único e idealizado.

A existência de diferenças de uso numa mesma língua é um fato incontestável e não uma anomalia restrita à língua portuguesa. Anomalia seria não haver diversidade, uma vez que uma língua se define como língua na medida em que seus usuários se comunicam por meio dela para conviverem socialmente. A variação das línguas resulta, 
principalmente, da flexibilidade inerente ao próprio código linguístico e da multiplicidade de usuários que dele se servem.

Com a comparação com outros resultados sobre o fenômeno da concordância verbal, acreditamos que revelamos a sistematicidade que existe na variação na concordância verbal da $3^{\text {a }}$ pessoa do plural. Mostramos que é uma variação altamente estruturada e não aleatória, caótica como muitos pensavam ser.

A concordância verbal é um fenômeno que não está imune à estigmatização, por ser um dos tópicos gramaticais que os professores de Língua Portuguesa mais controlam e, consequentemente, "penitenciam" com vigor as "falhas" de seus alunos.

Trata-se de um fenômeno muito saliente na percepção dos falantes que, muitas vezes, especialmente nos contextos de maior saliência emitem comentários negativos claros a respeito da falta de concordância principalmente com sujeitos plurais (eles vai) os menino vai). Isso sugere que a mudança está se dando em direção à norma de prestígio.

Supomos que o crescente prestígio de aplicação da regra de concordância (85\% tanto na modalidade falada, quanto na modalidade escrita), entre os segmentos populares riopretenses, faz com que essa variante se converta em um marcador social, desencadeando um processo de variação estilística, à medida que os falantes menos escolarizados vão adquirindo a consciência do valor social de uso da regra de concordância. De modo que os resultados referentes à investigação da variável extralinguística escolaridade mostraram que a variante concordância é ainda mais produtiva no nível escolar mais avançado que investigamos, tanto na modalidade falada quanto na escrita. 
Evidenciamos que a ausência de concordância verbal é condicionada, tanto na modalidade falada quanto na escrita, principalmente pelo menor nível de escolaridade e pelo menor nível de oposição entre o singular/plural das formas verbais. Sendo assim, os verbos de oposição inacentuada e sílaba final átona, como fala/falam, bebe/bebem, faz/fazem, apresentam grande probabilidade de desencadear a ausência de concordância verbal.

A falta de concordância vai diminuindo progressivamente à medida que se passa para as faixas mais jovens, em um padrão indicador de uma mudança em progresso no sentido da implementação da regra. Naro e Scherre (2007) verificaram uma tendência de mudança "para cima", em direção ao padrão urbano culto, isso porque os falantes mais jovens são os que apresentam o menor índice de cancelamento da regra de concordância, o que indica mais uma vez uma mudança aquisicional do português culto.

O índice de marcação da concordância verbal aumentou, conforme aumentava o grau de escolaridade do informante, o que nos mostra que essa variável é uma das principais responsáveis pela aplicação da regra de concordância verbal.

O aumento na taxa geral de uso de concordância é possivelmente facilitado e fortalecido através do aumento de uso de sujeitos com marcas formais de plural, desencadeando o paralelismo formal oracional, onde marcas levam a marcas. Acreditamos que a grande influência que o paralelismo formal exerce sobre a aplicação da regra da concordância verbal está relacionada a uma forte correlação existente entre a concordância nominal e a concordância verbal.

Observamos ainda que para o grupo de fatores posição do sujeito a aplicação da regra de concordância foi maior nos casos em que o sujeito se antepõe ao verbo. Os 
resultados vêm atestar, conforme apontam outros trabalhos, que o sujeito posposto ao verbo passa a ser "analisado" como objeto pelo falante, que, dessa forma, é levado à não aplicação da regra de concordância verbal.

Segundo Bagno (2007),

\begin{abstract}
pesquisas têm mostrado que muitos professores e professoras não corrigem essas contruções nos textos de seus alunos. Para esses docentes, a concordância do verbo com o sujeito posposto passou a ser uma regra "invisível", de tal modo que a não concordância se tornou "natural" para todos os falantes brasileiros de português, algo que não contradiz sua intuição de falante nativo. O conhecimento e o uso consciente da regra prevista na norma-padrão estão perdendo cada vez mais terreno, mesmo entre os falantes chamados "cultos", isto é, com vivência urbana e escolaridade superior completa (Marcos Bagno, 2007: 111).
\end{abstract}

Com os cruzamentos que realizamos entre os grupos de fatores foi possível verificar que um princípio não elimina o outro, mas acabam se conjugando na determinação do fenômeno variável em estudo. Não podemos deixar de ressaltar a importância dos cruzamentos nos estudos desta natureza, que revelam uma confluência entre os fatores determinantes na realização de uma variável linguística.

Como se trata de uma regra variável, uma das necessidades do professor é conhecer os condicionamentos dessa variação, para que possa desenvolver satisfatoriamente 0 trabalho com variados textos, especialmente no que se refere às diferentes variedades, modalidades e registros.

Segundo os resultados obtidos com o controle da variável saliência fônica, os exercícios devem focalizar os verbos regulares no presente e no imperfeito do indicativo, visto que nesses tempos há menor diferenciação fônica entre as formas singular e plural e, portanto menor tendência à concordância. No que diz respeito à 
variável posição do sujeito em relação ao verbo, os exercícios devem privilegiar as estruturas de sujeitos pospostos, que propiciam maior tendência ao cancelamento da marca de número do verbo.

O professor terá de distinguir as variantes sintáticas mais salientes e socialmente mais estigmatizadas, a fim de treinar o uso formal falado e o uso escrito de seus alunos.

Como diz Vieira (2008),

as reflexões ora apresentadas sobre o ensino da concordância verbal sublinham a importância do aproveitamento dos estudos linguísticos para uma prática de ensino que se quer pautada em normas reais, depreendidas dos diversificados contextos de uso da língua, do modo a fazer opções linguísticas conscientes na produção de textos orais e escritos (Vieira, 2008: 101).

Encerramos nossa pesquisa na certeza de que ela não se esgota com o término do trabalho, por apresentar um amplo campo a ser analisado, visto a complexidade do tema. 


\section{REFERÊNCIAS BIBLIOGRÁFICAS:}

ABREU, A. S. Gramática mínima: para o domínio da língua padrão. São Paulo: Ateliê Editorial, 2003;

ANJOS, S. E. Um estudo variacionista da concordância verbo-sujeito na fala pessoense. João Pessoa: Universidade Federal da Paraíba, 1999. Dissertação de Mestrado;

AQUINO SILVA, V. Análise da variação na concordância verbal em redações de vestibular. Brasília: UnB, 1997. Dissertação de Mestrado;

BAGNO. M. Preconceito lingüístico: o que é, como se faz. São Paulo: Loyola, 1999;

A língua de Eulália: novela sociolingüística. São Paulo: Contexto, 2001;

Português ou brasileiro? um convite à pesquisa. São Paulo: Parábola, 2004;

A norma oculta: língua \& poder na sociedade brasileira. São Paulo: Parábola, 2005;

. Nada na língua é por acaso: por uma pedagogia da variação lingüística. São Paulo: Parábola, 2007;

BECHARA, E. Moderna Gramática Portuguesa. São Paulo: Lucerna Editora, 2000;

BERLINCK, R. A ordem V SN no português do Brasil: sincronia e diacronia. Campinas, 1988. Dissertação de Mestrado, UNICAMP;

BORBA, F. S. Introdução aos Estudos Linguísticos. São Paulo: Companhia Editora Nacional, 1970;

Dicionário gramatical de verbos do português contemporâneo do Brasil. São

Paulo: Fundação Editora UNESP, 1991;

. Uma gramática de valências para o português. São Paulo: Ática, 1996; 
BORTONI-RICARDO, S. M. Educação em língua materna: a sociolingüística na sala de aula. São Paulo: Parábola, 2004;

. Um modelo para a análise sociolinguística do português brasileiro. In:

Nós cheguemu na escola, e agora? Sociolinguística \& educação. São Paulo: Parábola, 2005, p. 39-52;

A concordância verbal no português: um estudo de sua significação social: In: VOTRE, S.; RONCARATI, C. (orgs.). Anthony Julius Naro e a linguística no Brasil uma homenagem acadêmica. Rio de Janeiro: 7letras, 2008, p. 363-380.

BRAGA, M. L. A concordância de número no sintagma nominal no Triângulo Mineiro. Rio de Janeiro: PUC, 1997. Dissertação de Mestrado, inédito;

\& SCHERRE, M. M. P. A concordância de número no SN na área urbana do Rio de Janeiro. In: Encontro Nacional de Lingüística, 1976. Rio de Janeiro: PUC, 1976, p. 464-477;

BYBEE, J. Morphology $A$ study of the relation between meaning and form. Amsterdam/Philadelphia, Jonh Benjamins, 1985;

CÂMARA JR., J. M. Problemas de lingüística descritiva. 6.ed. Petrópolis: Vozes, 1973; Estrutura da língua portuguesa. 8. Ed. Petrópolis: Vozes, 1977; . Dicionário de Lingüística e Gramática. Petrópolis: Vozes, 1988;

CARDOSO, R. C. Variação na concordância verbal no indivíduo: um confronto entre o lingüístico e o estilístico. Universidade de Brasília, 2005. Dissertação de Mestrado, inédito;

CHAMBERS, J. K. Networks. In: Sociolinguistic theory. Oxford: Blackwell, p. 66-84, 1995;

COHEN, M. Manual para una sociologia del lenguaje. Madrid: Editora Fundamentos, 1974; 
COSERIU, E. Sistema, Norma e Falar Concreto. In: Lições de Linguística Geral. Rio de Janeiro: Ao Livro Técnico, 1980;

CUNHA, C. \& CINTRA, L. Nova Gramática do Português Contemporâneo. Rio de Janeiro: Editora Nova Fronteira, 2001;

CUNHA, C. Gramática da Língua Portuguesa. Rio de Janeiro: Editora Nova Fronteira, 1972 ;

DECAT, M. B. N. Concordância verbal, topicalização e posposição de sujeito. Ensaios de Linguística. Cadernos de Linguística e Teoria da Literatura. Organizadores: SIMÕES, A. M.; REIS, C. A. Faculdade de Letras da UFMG - Depto de Linguística e Teoria da Literatura. Ano v, n 9, Minas Gerais, 1983;

DIK, C. S. Functional Grammar. Dorderechet-Holland/Cinnaminson. EUA: Foris Publications, 1978;

FARACO, C. A. Norma-padrão brasileira: desembaraçando alguns nós. In: Bagno, Marcos (orgs.) Linguística da norma. São Paulo: Loyola, 2002;

2008 ;

Norma culta brasileira: desatando alguns nós. São Paulo: Parábola Editorial,

GALVES, C. C. O enfraquecimento da concordância no português brasileiro. In: ROBERTS, I. e KATO, M. A. (orgs.) Português Brasileiro: uma viagem diacrônica: homenagem a Fernando Tarallo. Campinas: Editora da Unicamp, p. 387-408, 1993;

GAMEIRO, M. B. A concordância verbal na língua falada da região central do estado de São Paulo. Araraquara: UNESP, 2005. Dissertação de Mestrado;

A variação da concordância verbal na $3^{\underline{a}}$ pessoa do plural em redações escolares do ensino fundamental e médio. Araraquara: UNESP, 2009. Tese de doutorado. No prelo;

GILI GAYA, S. Curso Superior de Sintaxis Española. Madrid: Editora Vox, 2000; 
GONÇALVES, S. C. L. O português falado na região de São José do Rio Preto: constituição de um banco de dados anotado para o seu estudo. Relatório Científico apresentado à FAPESP, 2005;

GONÇALVES, S. C. L.; TENANI, L. E. Problemas teórico-metodológicos na elaboração de um sistema de transcrição de dados interacionais: o caso do projeto ALIP (Amostra Linguística do Interior Paulista). Revista Gragoatá, 2ํㅗ semestre de 2008;

GRACILIANO da SILVA, T. L. A concordância da $3^{\underline{a}}$ pessoa do plural em redações escolares. Rio de Janeiro: UFRJ, 2009. Dissertação de Mestrado;

GUIMARÃES, E.; ORLANDI, E. O conhecimento sobre a linguagem. In: Introdução às Ciências da Linguagem - Linguagem, História e Conhecimento. J. H. Nunes e C. C. Pfeiffer (Orgs.). Campinas: Pontes, 2006, p. 141-157;

GUY, G. Identidade linguística da comunidade de fala: paralelismo interdialetal nos padrões de variação linguística. Organon. Revista do Instituto de Letras da UFRGS, Porto Alegre, v. 28 e 29, p. 17-32, 2000;

HALLIDAY, M. A. K. An Introduction to Functional Grammar. Baltimore: Edward Arnold, 1985;

HOUAISS, A. Dicionário Houaiss da Língua Portuguesa. Rio de Janeiro: Editora Objetiva, 2002;

LABOV, W. Sociolinguistic Pattems. Philadelfia: University of Pensylvania Press, 1972;

Padrões Sociolinguísticos. [1972] Tradução: Marcos Bagno, Maria Marta Pereira Scherre, Caroline Rodrigues Cardoso. São Paulo: Parábola Editorial, 2008;

LEMLE, M.; NARO, A. J. Competências básicas do português. Relatório final de pesquisa apresentado às instituições patrocinadoras Fundação Movimento Brasileiro de Alfabetização (Mobral) e Fundação Ford, 1977;

LUCCHESI, D. Sistema, Mudança e Linguagem: um percurso na história da lingüística moderna. Parábola, 2004; 
Parâmetros sociolinguísticos do Português do Brasil. Revista da Abralin, vol. 5, no 1 e 2, dez. 2006;

MARCUSCHI, L. A. Da fala para a escrita: atividades de retextualização. São Paulo: Cortez, 2003;

MARTELOTTA, M. E. (org.). Manual de lingüística. São Paulo: Contexto, 2008;

MATEUS, M. H. M. et alii. Gramática da língua portuguesa. Coimbra: Almedina, 1983;

MATTE BOM, F. Gramática Comunicativa del Español. EDELSA, 1995;

MATTOS e SILVA, Rosa Virgínia. O português são dois: novas fronteiras, velhos problemas. São Paulo: Parábola, 2004;

MILROY, L. Language and social networks. Oxford: Blackwell, 1980;

Observing and analysing natural language - a critical account of sociolinguistic method. Oxford: Blackwell, 1987;

Social networks. In: J. K. CHAMBERS; P. TRUDGILL; N. SCHILLING-ESTES (eds.). The Handbook of language variation and change. Oxford: Blackwell, p. 549-569, 2002;

MOLLICA, M. C.; BRAGA, M. L. (orgs.) Introdução à sociolinguística - o tratamento da variação. São Paulo: Contexto, 2003;

MONGUILHOT, I. O. S. Variação na concordância verbal de terceira pessoa do plural na fala dos floripolitanos. Florianópolis: Universidade Federal de Santa Catarina, 2001. Dissertação de Mestrado, inédito;

. Estudo sincrônico e diacrônico da concordância verbal de terceira pessoa do plural no PB e no PE. Florianópolis: Universidade Federal de Santa Catarina, 2009. Tese de Doutorado, inédito;

MONGUILHOTT, I. O. S.; COELHO, I. L. Um estudo da concordância verbal de terceira pessoa em Florianópolis. In: VANDRESEN, P. Variação e mudança no português falado na região sul. Pelotas: Educat, 2002; 
MONTE, A. Concordância verbal e variação: uma fotografia sociolinguística da cidade de São Carlos. Araraquara: UNESP, 2007. Dissertação de Mestrado;

MONTEIRO, J. L. Morfologia portuguesa. Campinas: Pontes, 2002;

NARO, A. J. The social and structural dimensions of a syntactic change. Language 57 (1): p. 63-98, 1981;

NARO, A. J.; LEMLE, M. Syntatic Diffusion. In: Papers from de Parasession on Diachronic Syntax. Chicago: Chicago Linguistic Society - CLS, v. 29, n.3, 1976;

NARO, A. J.; SCHERRE, M. M. P. Variação e mudança lingüística: fluxos e contrafluxos na comunidade de fala. In: SILVA, G.M.O.; TARALLO, F. (orgs.). Cadernos de estudos lingüísticos 20:9-16, 1991;

. Origens do Português Brasileiro. São Paulo: Parábola Editorial, 2007;

NEVES, M. H. M. A gramática funcional. São Paulo: Martins Fontes, 1997;

. Gramática de Usos do Português. São Paulo: Editora UNESP, 2000;

OLIVEIRA E SILVA, G. M.; SCHERRE, M. M. P. (orgs.) Padrões sociolinguísticos análise de fenômenos variáveis do português falado no Rio de Janeiro: Tempo Brasileiro, 1996;

PAGOTTO, E. Sociolingüística. In: Introdução às Ciências da Linguagem - Linguagem, História e Conhecimento. J. H. Nunes e C. C. Pfeiffer (orgs.). Campinas: Pontes, 2006, p. 49-72;

PAIVA, M. C. (org.) Amostras de fala do português falado no Rio de Janeiro. Rio de Janeiro: UFRJ, 1999;

PAIVA, M. C.; DUARTE, M. E. L. (orgs.). Mudança linguística em tempo real. Rio de Janeiro: Contra Capa, 2003;

PALADINO, V. C. et al. Sintaxe de concordância nominal e verbal: teoria e prática. Rio de Janeiro: Freitas Bastos, 2006; 
PEREIRA, A. K. A concordância nominal, verbal e nos predicativos em função das situações de fala de um único falante. Brasília: UNB, 1993. Inédito;

PEREIRA, M. A. B. Gênero e número em português: estudo das relações forma-sentido na gramática. Rio de Janeiro: UFRJ, 1987;

PONTES, E. S. L. Sujeito: da sintaxe ao discurso. São Paulo: Ática, 1986;

POSSENTI, S. Por que (não) ensinar gramática na escola? Campinas. São Paulo: Mercado de Letras, 1999;

PRETI, D. Sociolingüística: os níveis de fala, um estudo sociolingüístico do diálogo literário. São Paulo: Nacional, 1974;

ROCHA LIMA, C. H. Gramática normativa da língua portuguesa. 15 ed. Rio de Janeiro: José Olympio, 1972;

ROCHA MATTOS, S. E. Sujeito coletivo singular em português: concordância e referencialidade. Brasília: UnB, 2003. Dissertação de Mestrado, inédito;

RODRIGUES, A. C. S. A concordância verbal no português popular em São Paulo. São Paulo, USP, 1987. Tese de doutorado;

ROJO, R. Letramentos múltiplos, escola e inclusão social. São Paulo: Parábola Editorial, 2009;

SACCONI, L. A. Nossa Gramática: Teoria. 22 ed. Sâo Paulo: Atual, 1990;

SAID ALI, Gramática Elementar da Língua Portuguesa. São Paulo: Edições Melhoramentos, 1969;

SCHERRE, M. M. P. A regra de concordância de número no sintagma nominal em Português. Rio de Janeiro, PUC, 1978. Dissertação de Mestrado, inédito; 
Reanálise da concordância nominal em português. Rio de Janeiro, PUC, 1988. Tese de Doutorado, inédito;

Reanálise da concordância nominal em português. Boletim da Associação Brasileira de Lingüística 11:97-124, 1989;

A concordância de número nos predicativos e nos particípios passivos. Organon - A variação no português do Brasil 18(5):52-70, 1991;

Paralelismo formal e cognição. Boletim da Associação Brasileira de Lingüística 13:43-53, 1992;

Duas dimensões do paralelismo verbal no português popular do Brasil. DELTA $\overline{9(1): 1-14,1993 ;}$

Paralelismo linguístico. In: Revista de Estudos da Linguagem: Faculdade de Letras da UFMG. Belo Horizonte, v. 7, n. 2, p. 29-59, 1998;

Doa-se lindos filhotes de poodle: variação linguística, mídia e preconceito. São Paulo: Parábola Editorial, 2005;

SCHERRE \& NARO. Marking in Discourse: Birds of a Feather. In: Language Variation and Change. v.3, p.23 - 32, 1991;

Duas dimensões do paralelismo formal na concordância verbal no português popular do Brasil. In: Revista de Documentação em Estudos em Lingüística Teórica e Aplicada. v. 9, n. 1, p. 1-14, 1993;

A concordância de número no Português do Brasil: um caso de variação inerente. In: HORA, D. (org.). Diversidade linguística no Brasil. João Pessoa: Idéia, 1997 ;

Restrições sintáticas e semânticas no controle da concordância verbal em português. Fórum Linguístico: Pós-Graduação em Linguística, UFSC. Florianópolis, p. 45-71, 1998; 
SCHERRE, M. M. P.; NARO, A.. J.; CARDOSO, C. R. O papel do tipo de verbo na concordância verbal no português brasileiro. DELTA. Documentação de Estudos em Linguística Teórica e Aplicada, v.23, p. 283-317, 2007;

SILVA-CORVALAN, C. Sociolingüística: teoría y analisis. Madrid: Editorial Alhambra, 1989;

TARALLO, F. A pesquisa sociolinguística. São Paulo: Ática, 1994;

TRAVAGLIA, L. C. Um estudo textual-discursivo do verbo no português do Brasil. Campinas, UNICAMP, 1991. Tese de doutorado;

VIEIRA, S. R. Variação em dialetos populares do norte fluminense. Rio de Janeiro, UFRJ, 1995. Dissertação de Mestrado, inédito;

VIEIRA, S. R.; BRANDÃO, S. F. (orgs.). Ensino de gramática: descrição e uso. São Paulo: Contexto, 2008;

WEINREICH, U., W. LABOV \& M. HERZOG (1968) Fundamentos empíricos para uma teoria da mudança lingüística. Trad. Marcos Bagno; revisão técnica Carlos Alberto Faraco. São Paulo: Parábola Editorial, 2006. 